UNIVERSIDADE DE SÃO PAULO

FACULDADE DE FILOSOFIA, LETRAS E CIÊNCIAS HUMANAS DEPARTAMENTO DE LETRAS ORIENTAIS

PROGRAMA DE LITERATURA E CULTURA RUSSA

PRISCILLA HERRERIAS

\title{
A poética dramática de Tchékhov: um olhar sobre os problemas de comunicação
}

Versão corrigida 
UNIVERSIDADE DE SÃO PAULO

FACULDADE DE FILOSOFIA, LETRAS E CIÊNCIAS HUMANAS

DEPARTAMENTO DE LETRAS ORIENTAIS

PROGRAMA DE LITERATURA E CULTURA RUSSA

\title{
A poética dramática de Tchékhov: um olhar sobre os problemas de comunicação
}

\author{
Priscilla Herrerias
}

\begin{abstract}
Dissertação em versão corrigida apresentada ao Programa de Pós-graduação em Literatura e Cultura Russa do Departamento de Letras Orientais da Faculdade de Filosofia, Letras e Ciências Humanas da Universidade de São Paulo como requisito para obtenção do título de Mestre em Literatura e Cultura Russa. Pesquisa desenvolvida com apoio da Fundação de Amparo à Pesquisa do Estado de São Paulo (FAPESP).
\end{abstract}

De acordo,

Orientadora: Prof. Dra. Elena Vássina

São Paulo

2010 
Autorizo a reprodução e divulgação total ou parcial deste trabalho, por qualquer meio convencional ou eletrônico, para fins de estudo e pesquisa, desde que citada a fonte.

Herrerias, Priscilla

A poética dramática de Tchekhóv : um olhar sobre os problemas de comunicação / Priscilla Herrerias ; orientadora Elena Vássina. - São Paulo, 2010.

126 f. ; il.

Dissertação (Mestrado) - Faculdade de Filosofia, Letras e Ciências Humanas da Universidade de São Paulo. Departamento de Letras Orientais. Área de concentração: Literatura e Cultura Russa.

1. Teatro (literatura) - Rússia. 2. Literatura russa. 3. Tchekhóv, Anton, 1860-1904. I. Título. II. Vássina, Elena. 


\section{A poética dramática de Tchékhov: um olhar sobre os problemas de comunicação}

Dissertação de mestrado em versão corrigida apresentada ao Programa de pós-graduação em Literatura e Cultura Russa do Departamento de Letras Orientais da Faculdade de Filosofia, Letras e Ciências Humanas da Universidade de São Paulo, aprovada pela Banca Examinadora constituída pelos seguintes professores:

Prof. Dra. Elena Vássina

Faculdade de Filosofia, Letras e Ciências Humanas Universidade de São Paulo

Orientadora

Prof. Dr. Antônio Carlos de Araújo Silva Escola de Comunicações e Artes Universidade de São Paulo

Prof. Dr. Jorge Mattos Brito de Almeida

Faculdade de Filosofia, Letras e Ciências Humanas Universidade de São Paulo 
À memória de José Moleiro

Para Jair Fernandes 


\section{AGRADECIMENTOS}

Ao Fundo de Amparo à Pesquisa do Estado de São Paulo (FAPESP) pela viabilização da pesquisa.

À Prof. Dra. Elena Vássina, pela orientação incentivadora, generosidade e alegria com que compartilha seu conhecimento e amor pelo teatro e literatura.

Aos Profs. Drs. Jorge de Almeida e Mário Francisco Júnior pelas valiosas contribuições quando do exame de qualificação.

À Pablo Ferreira, pelas constantes leituras, incentivo e apoio incondicional.

À Tieza Tissi, pela revisão atenta, conversas estimulantes, sugestões e críticas.

À Graziella Schneider e Priscila Nascimento Marques, por sanarem tantas dúvidas, sempre com muita disponibilidade.

À André Blumenschein, Chico Carvalho, Dinah Feldman, Fabricio Licursi, Felipe Schermann, Fernanda Viacava, Francisco Medeiros, Márcio Castro e Pablo Ferreira pela aventura tão prazerosa e cheia de aprendizagem de Réquiem.

À Isabel Setti, Lu Favoreto e todos os atores do Núcleo Experimental do Teatro Popular do Sesi 2004-2005, pelos momentos preciosos vivenciados.

À Adolf Shapiro, Aury Porto, Diego Moschokovich, Fredy Allan, Luah Guimarãez, Lúcia Romano, Sérgio Siviero, Sílvio Restiffe, Sylvia Prado, Vanderlei Bernardino e Tieza Tissi pela maravilhosa experiência de Tchékhov ${ }^{4}$.

Aos meus pais, Valter e Ivone, e irmãos, Lika e Ju, pelo apoio e presenças sempre iluminadas. 
Não há mensagem, há mensageiros, e isso éa mensagem, assim como o amor é o que ama.

Júlio Cortázar, Rayuela. 
HERRERIAS, Priscilla. A poética dramática de Tchékhov: um olhar sobre os problemas de comunicação. São Paulo: 2010, 126f. Dissertação (Mestrado em Literatura e Cultura Russa) Faculdade de Filosofia, Letras e Ciências Humanas, Universidade de São Paulo.

\section{RESUMO}

As lacunas nos processos de comunicação entre as personagens dramáticas de Anton Tchékhov (1860-1904) apresentam-se como um traço básico e definitivo de sua poética. A análise dos processos comunicativos entre as personagens das quatro principais peças do autor - A gaivota (1896), O tio Vânia (1897), As três irmãs (1900) e O jardim das cerejeiras (1904) - elucida a criação de um novo paradigma artístico em seu sistema dramático, cujas inovações marcaram profundamente todo o teatro do século XX e exercem enorme influência até os dias de hoje. O presente trabalho apresenta um recorte das obras selecionadas em relação ao contexto russo da época, evidenciando inquietações que anunciavam transformações profundas na sociedade. Neste intuito, retoma a teoria dos gêneros literários e suas principais críticas, que realçaram a importância da relação entre os gêneros e o momento histórico em que se consolidavam; assim, adquire relevo nas análises o conceito de "romantização" dos gêneros proposto pelo filósofo e teórico literário russo Mikhail Bakhtin (1895-1975), a partir da ideia de "supremacia" do único gênero em devir. Com a emersão de elementos épicos e líricos na dramaturgia tchekhoviana, observa-se como o diálogo, forma do gênero dramático por excelência, motor das ações que impulsionam o avanço do enredo no sistema dramático tradicional, tem sua unidade enfraquecida, fazendo com que o drama tchekhoviano necessite da encenação para realizar-se plenamente. O "invisível" e o "indizível", aquilo que subjaz às réplicas, que está latente justamente nas lacunas dos processos comunicativos entre as personagens, torna-se vital a este novo teatro, que acolhe e conta com a imaginação de leitores/espectadores.

Palavras-chave: Anton Tchékhov, Teatro russo, Drama moderno, Teoria teatral, Literatura russa. 
HERRERIAS, Priscilla. Chekhov's dramatic poetics: a view on the communication problems. São Paulo: 2010, 126f. Dissertação (Mestrado em Literatura e Cultura Russa) - Faculdade de Filosofia, Letras e Ciências Humanas, Universidade de São Paulo.

\begin{abstract}
The gaps in the communication processes between the dramatic characters of Anton Chekhov (1869-1904) consist on a basic and definite trait of the author's dramatic poetics. The analysis of the communication processes of four of Chekhov's major plays - The seagull (1896), Uncle Vanya (1897), Three sisters (1900) and The cherry orchard (1904) - elucidate the creation of a new artistic paradigm in the author's dramatic system, the innovations of which deeply affected the twentieth century theatre and have exerted a major influence until today. The study approaches the selected plays firstly considering the Russian context of the period, highlighting historical transformations that were already on course. Secondly, it examines the literary genres theory, as well as the most important criticism it suffered. The concepts developed by the Russian philosopher and literary critic Mikhail Bakhtin (1895-1975), which took into account the relationship between the literary genres and the historical moments when they were being shaped, acquire great importance in our analysis. Specially the notion of the novel as a contemporary genre, which embraces and affects all the other genres. After clarifying this influence by identifying the presence of epic and lyric elements in Chekhov's plays, we observe how the dialogue, the traditional form of the dramatic genre, motor of the actions that push the plot forward, has its unit weakened. As a consequence, chekhovian drama needs staging to be fully achieved: what is not visible and cannot be reduced to words, what is latent in the gaps of communication, underlying the characters' speeches, become vital to this new theatre, which welcomes and counts on the imagination of its audience.
\end{abstract}

Key-words: Anton Chekhov, Russian theatre, Modern drama, Drama theory, Russian literature. 


\section{LISTA DE ILUSTRAÇÕES}

SHAPIRO, Adolf. Tchékhov ${ }^{4}$ - um estudo cênico, 2010. $3^{\text {o. }}$ ato

SHAPIRO, Adolf. Tchékhov ${ }^{4}$ - um estudo cênico, 2010. $1^{\text {o. }}$ ato 46

FOMENKO, Piotr. As três irmãs, 2004. $3^{\text {o. }}$ ato 64

SHAPIRO, Adolf. Tchékhov ${ }^{4}$ - um estudo cênico, 2010. $3^{\text {o. }}$ ato 79

STREHLER, Giorgio. O jardim das cerejeiras, $1973.1^{\circ}$ ato 83

FOMENKO, Piotr. As três irmãs, 2004. $4^{\text {o. }}$ ato

KONCHALÓVSKI, Andrei. O tio Vânia, 1971. 00:07:09

103

KONCHALÓVSKI, Andrei. O tio Vânia, 1971. 00:14:11

103

KONCHALÓVSKI, Andrei. O tio Vânia, 1971. 00:14:23

104

KONCHALÓVSKI, Andrei. O tio Vânia, 1971. 00:36:03

104

DÓDIN, Liév. A gaivota, 2001. $1^{\circ}$. ato

116 


\section{SUMÁRIO}

Introdução 12

Trajetória da pesquisa 16

Um autor de interrogações e reticências 24

Tempo de transição e incertezas ou "Neste mundo não se compreende nada" 28

A ambivalência do progresso sob diferentes perspectivas 33

Uma imagem idílica construída a cada dia: Moscou 39

O teatro dentro do teatro: novas e velhas formas 44

Olhamos as estrelas, mas por quê voamos tão baixo? 47

Inovações do sistema dramático tchekhoviano 52

Aspectos gerais da teoria dos gêneros literários $\quad 54$

Sobre a ação e o diálogo no gênero dramático rigoroso 59

Sobre a ação e o diálogo no sistema dramático tchekhoviano 61

A emersão de elementos épicos e líricos

O "invisível" e o "indizível" na cena tchekhoviana

Objetos e espaços 76

Sons e silêncios $\quad 86$

$O$ "invisivel", o "indizivel" e os problemas de comunicação

Constelações paralelas 98

Monólogos sobrepostos ou um "diálogo de surdos" 110

Uma paródia 113

$\begin{array}{ll}\text { Considerações finais } & 115\end{array}$

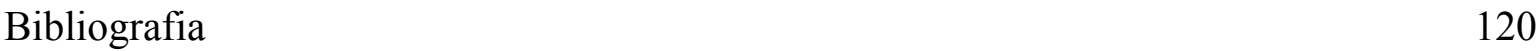

$\begin{array}{ll}\text { Encenações e filmes citados } & 126\end{array}$ 


\section{INTRODUÇÃO}

In an age of ruddy Goliaths it is very useful to read about delicate Davids. Vladímir Nabókov ${ }^{1}$

No ano em que se celebram os cento e cinquenta anos de nascimento de Anton Pávlovitch Tchékhov (1860-1904), um dos maiores e mais queridos contistas e dramaturgos, artistas, pesquisadores, espectadores e leitores dos quatro cantos do mundo ainda sentem-se instigados por sua obra. Ao contrário do que pensava o autor - "[...] tudo o que escrevi [...] não resistirá ao esquecimento por mais de dez anos" (TCHÉKHOV, 2002a, p. 75) - sua obra continua viva, sendo lida e encenada nos mais diversos países, sob as mais diferentes propostas e a pertinência das questões levantadas ainda nos proporciona momentos de plenitude e encanto.

Um dos mais importantes encenadores teatrais da atualidade, o diretor alemão Peter Stein $^{2}$ (1937-), em janeiro deste ano nas comemorações moscovitas para o aniversário do autor, declarou que Tchékhov era tão importante para o teatro quanto a tragédia grega e William Shakespeare (1564-1616): "Essas são as três colunas básicas do teatro europeu. Shakespeare reinventou os gregos para os tempos modernos e Tchékhov para o século vinte" ${ }^{3}$. Stein ainda destacou a influência de Tchékhov na prosa e na dramaturgia contemporâneas, cujos autores puderam aprofundar e radicalizar as inovações corajosamente empreendidas pelo autor de $A$ gaivota (1896) e Uma história enfadonha (1889):

Todos eles, autores de prosa e dramaturgos, de uma maneira ou de outra, se apóiam nas descobertas feitas por Tchékhov. Isto se aplica totalmente mesmo a autores que criaram textos dramáticos dentro de padrões estéticos completamente diversos. Por exemplo, Beckett "absurdista" também se encontra "ao lado" de Tchékhov (STEIN, 2010, p. 81).

Nascido em Taganrog, pequena cidade ao sul da Rússia no mar de Azov, filho de um comerciante e neto de servos, Tchékhov iniciou sua carreira literária ainda muito jovem. Com

\footnotetext{
1981 , p. 255.

2 Diretor de teatro e ópera, estabeleceu-se na Schaubühne am Lehniner Platz, companhia que levou à vanguarda do teatro alemão nos anos setenta. De Tchékhov dirigiu As três irmãs (1984), O jardim das cerejeiras (1995) e $A$ gaivota (2003).

${ }^{3}$ STEIN, Peter. Entrevista concedida a Amie Ferris-Rotman e Iúri Púchkin. Moscou, 2010. Disponível em: http://entretenimento.uol.com.br/ultnot/reuters/2010/01/29/ult26u29717.jhtm. Acesso em: 01 fev. 2010.
} 
a falência do pai, a família viu-se obrigada a deixar a província e mudar-se para Moscou, fugindo dos credores. O jovem Tchékhov permaneceu sozinho em Taganrog para terminar os estudos no liceu e só três anos mais tarde juntou-se à família na capital, quando ingressou no curso de medicina. Já nesta época, apesar das exigências dos estudos na universidade, sustentava os pais e os três irmãos com o que ganhava dando aulas e escrevendo pequenos contos humorísticos para jornais e revistas.

Ao concluir o curso de medicina em 1884, Anton Pávlovitch publica sua primeira obra, intitulada Contos de Melpômene, uma reunião de trabalhos escritos para a imprensa humorística. Ainda escrevendo sob pseudônimos, dentre eles "Antocha Tchekhonté", em 1885 inicia colaborações com jornais de maior peso, tornando-se acessível a um novo público, mais exigente.

O ano seguinte foi decisivo para a carreira literária de Tchékhov. Encantado pelos contos do jovem autor, Dmítri V. Grigoróvitch (1822-1889), então escritor de grande influência em São Petersburgo, pediu a Tchékhov em carta, que este deixasse de escrever sob pseudônimos e abandonasse os trabalhos apressados, feitos sob encomenda; em poucas palavras, que valorizasse seu talento. E ainda acrescentou profeticamente:

Estou certo de que o senhor está destinado a escrever obras verdadeiramente magníficas. Cometerá um grande pecado se não corresponder a tais expectativas. Para isso, é necessário o seguinte: respeitar um talento que se recebe tão raramente [...] (apud ANGELIDES, 1995, p. 22).

Profundamente afetado pela carta de Grigoróvitch, Tchékhov fez uma reflexão rigorosa sobre seu trabalho literário, chegando mesmo a subestimar toda sua obra passada. $\mathrm{O}$ autor, que sempre se dividiu entre a medicina, sua "esposa legítima", e a literatura, sua "amante", como ele mesmo dizia (TCHÉKHOV, 2002a, p. 61), na resposta a Grigoróvitch reafirmou seu compromisso consigo mesmo e com o futuro, com a modéstia sincera e íntegra que sempre lhe acompanhou: "Tenho apenas vinte e seis anos. Talvez eu ainda tenha tempo para fazer alguma coisa, embora o tempo passe depressa" (apud ANGELIDES, 1995, p. 49).

Nos dezoito anos que se seguiram, desde a carta de Grigoróvitch até a morte prematura de Tchékhov, o autor não só se dedicou ao conto e ao drama (sem nunca abandonar a medicina), como instaurou mudanças profundas que alteraram seus paradigmas. As personagens complexas, que escapam às classificações de heróis ou vilões, a riqueza dos detalhes, das pequenas coisas da vida que atingem uma dimensão metafórica, os finais reticentes, inacabados, que valorizam o fluxo da própria vida ante grandes acontecimentos 
fictícios, configuram uma poética que abriu novas possibilidades tanto para o conto quanto para o drama a partir de fins do século XIX.

Tchékhov, ao lado de $\operatorname{Ibsen}^{4}$ (1828-1906), Strindberg ${ }^{5}$ (1849-1912) e Maeterlinck ${ }^{6}$ (1862-1949), foi considerado um dos principais criadores do que se chamou "drama novo", localizado na passagem para o século XX. Ao alterar principalmente os conceitos de ação e diálogo, estes autores redefiniram as bases da dramaturgia e embora não tenham rompido completamente com a tradição que os precedia, instauraram mudanças significativas que sem dúvida influenciaram e influenciam dramaturgos até os dias de hoje.

Na conferência internacional Uma palavra sobre Tchékhov realizada em janeiro de 2010 em Moscou, diretores, atores e pesquisadores enfatizaram a importância de Tchékhov para a prosa e dramaturgia contemporâneas. Na mesma ocasião, o polêmico diretor Franz Castorf $^{7}$ (1951-) afirmou que a dramaturgia de Tchékhov tem sido mal compreendida; para o encenador, o principal elemento que perpassa as peças de Tchékhov é o estranhamento, causado pelo tema da incomunicabilidade, a nosso ver, motor das inovações da poética dramática tchekhoviana, mais tarde exaustivamente tratado e radicalizado pela dramaturgia do século XX. Castorf observa ainda que a peculiaridade dos diálogos tchekhovianos faz com que além de dramaturgo, o autor também se torne poeta e músico:

Parece que as pessoas se comunicam, se envolvem nos diálogos, mas na realidade estes são intermináveis monólogos - líricos e musicais. E o que é maravilhoso neste sentido, é que aqui não estamos tratando apenas com o dramaturgo, mas com o poeta e o músico (CASTORF, 2010, p. 110).

O renomado especialista em teatro russo Anatóli Smeliánski ${ }^{8}$ concorda com Castorf, mas ressalta que muitas encenações das peças de Tchékhov, principalmente a partir dos anos 1960, já se consolidavam sobre o tema da incomunicabilidade. Nas palavras de Smeliánski, as

\footnotetext{
${ }^{4}$ Henrik Johan Ibsen, dramaturgo norueguês, um dos principais autores do fim do século XIX. Dentre suas peças encontram-se Peer Gynt (1867), A casa de bonecas (1879), O pato selvagem (1884), Rosmersholm (1886) e Hedda Gabler (1890).

5 August Strindberg, dramaturgo e prosador sueco, considerado ao lado de Ibsen, um dos maiores autores escandinavos. Dentre suas peças destacam-se Senhorita Júlia (1888), O caminho de Damasco (1898) e O sonho (1901).

${ }^{6}$ Maurice Maeterlinck, poeta, ensaísta e dramaturgo belga. O autor das peças Pelléas e Mélisande (1892), A morte de Tintagiles (1894) e O pássaro azul (1908) foi um dos principais expoentes do movimento simbolista.

${ }^{7}$ Encenador alemão, desde 1992 é diretor artístico da Volksbühne am Rosa-Luxemburg-Platz. Em janeiro de 2010 realizou uma polêmica montagem no Festival Internacional de Teatro A. Tchékhov de Moscou, a partir de As três irmãs (1900) e o conto Os mujiques (1897).

${ }^{8}$ Teórico teatral, crítico e um dos diretores artísticos do Teatro de Arte de Moscou desde 1996.
} 
personagens tchekhovianas das montagens do diretor russo Anatóli Éfros ${ }^{9}$ (1925-1987), por exemplo, "estão gritando, lutando para se fazerem ouvidas, presas a um discurso histérico, intenso e contínuo e... sem ouvir umas às outras" (SMELIANSKY, 2010, p. 142).

A falta de escuta e contato entre as personagens do teatro tchekhoviano parece ecoar o próprio mundo de hoje, dominado pela linguagem virtual, em que deixamos em blogs nossos gritos e desabafos monológicos. Em um tempo que cada vez mais alimenta o individualismo cego e cujas inovações tecnológicas, se por um lado permitem maior comunicação, por outro nos afastam do contato real, o olhar de Tchékhov parece manter-se surpreendentemente atual e instigante.

Sentindo-se em constante dívida com a medicina, apesar das intensas atividades da carreira literária, o autor nunca deixou de exercê-la; além do trabalho em hospitais, foi durante 1892, ano em que a epidemia do cólera assolava o interior da Rússia, o único médico responsável por vinte e cinco aldeias, atendendo milhares de camponeses sem nada lhes cobrar.

Ainda movido por esta dívida, embora já sofresse com a tuberculose que causaria sua morte catorze anos depois, Tchékhov viajou dez mil quilômetros até a ilha de Sacalina, colônia de trabalhos forçados no extremo oriente da Rússia. $\mathrm{O}$ autor entrevistou pessoalmente os mais de dez mil moradores do local, entre colonos e forçados, realizando um exaustivo recenseamento da população e um estudo sociogeográfico: "Passei por todos os povoados, entrei em todas as isbás ${ }^{10}$, falei com todo mundo; [...] Em poucas palavras, não há em Sacalina um único forçado ou colono que não tenha conversado comigo" (TCHÉKHOV, 2002a, p. 318). Alarmado com a precária condição de vida da população local, em seu regresso publicou $A$ ilha de Sacalina (1895), obra que ajudou a promover uma reforma no sistema penal e a melhorar a realidade de forçados e colonos.

O olhar que enxergava as pessoas e a realidade com a precisão de um bisturi está ainda, carregado do amor e compaixão que Tchékhov nutria pelo ser humano. Em sua poética dramática evidencia-se a capacidade do autor em amar suas personagens sem nunca sentimentalizá-las nem julgá-las, de retratá-las presas a uma realidade cotidiana sem surpresas, o que as aproximam de leitores/espectadores dos mais diferentes lugares e épocas. Apesar da realidade dura e insensível em que estão mergulhadas, não deixam de sonhar. Neste

\footnotetext{
${ }^{9}$ Encenador teatral russo com montagens marcantes de textos de Tchékhov. Foi diretor do Teatro Taganka de Moscou nos últimos vinte anos de sua vida.

${ }^{10}$ Típica habitação rural russa.
} 
sentido, Vladímir Nabókov ${ }^{11}$ (1899-1977) capta com beleza a condição das personagens tchekhovianas: seres que frequentemente tropeçam; mas tropeçam porque olham as estrelas (NABOKOV, 1981, p. 254).

Amigo e correspondente de Tchékhov, o escritor Maksim Górki ${ }^{12}$ (1868-1936), assim expressou a delicadeza e a dor presentes em sua poética:

Ele era de uma modéstia casta e não se permitia dizer às pessoas em alto e bom tom: "Afinal sejam mais... honestas!", esperando em vão que elas atinassem a necessidade premente de serem honestas. Odiando tudo o que era vulgar e sujo, ele descrevia as torpezas da vida com a nobre linguagem de poeta, com leve riso de humorista, e, por trás da bela aparência de seus contos, não é muito perceptível seu sentido latente, cheio de censuras amargas (GÓRKI, 2006, p. 91).

Tchékhov - contista, dramaturgo e médico - tinha a habilidade de verdadeiramente ver e testemunhar. Avesso a qualquer tipo de julgamento, buscou a liberdade, lutando contra a ignorância e a escravidão, onde quer que se manifestassem. Através de sua arte, transforma o presente da vida cotidiana em momentos de eternidade, permeados por um humor sutil e delicado; com o olhar que atravessa a dor e a dureza da luta pela sobrevivência, traz à tona o infinito, dialogando com leitores/espectadores mesmo depois dos cento e cinquenta anos de seu nascimento.

Trajetória da pesquisa

Desde meu primeiro contato com a obra de Tchékhov, ainda na graduação em Artes Cênicas pela Universidade Estadual de Campinas (1997-2000), quando pude estudar algumas de suas peças em disciplinas teóricas, senti-me instigada com as inovações de sua poética. No âmbito da prática, a oportunidade de mergulhar em suas peças veio só alguns anos mais tarde, mas lembro-me de que já naquela época este era um desejo latente.

\footnotetext{
${ }^{11}$ Vladímir Vladimírovitch Nabókov, romancista, contista, crítico, professor e entomologista russo. Escreveu suas obras em russo e também em inglês. A partir das aulas ministradas na Universidade Cornell por dez anos (1948-1958), surge a publicação Lectures on Russian literature (1981).

${ }^{12}$ Maksim Górki, autor de romances, contos e peças como Os pequenos burgueses (1901) e Os filhos do sol (1905). Apesar do estilo bem diverso que assumiria, considerava Tchékhov um de seus mestres. A correspondência entre os dois autores pode ser conferida em Carta e literatura: correspondência entre Tchékhov e Górki, de Sophia Angelides (2001).
} 
Palavras frequentemente associadas à dramaturgia do autor e em que se baseiam muitas encenações - tédio, ócio, melancolia - e que justificam opiniões de que suas peças são "chatas", "sem vida", "monótonas", sempre me pareceram visões de leituras superficiais, equívocos que me levaram a querer debruçar-me sobre sua dramaturgia. É claro que estes temas são presentes nas obras de Tchékhov, mas se chocam com personagens cheias de sonhos e desejos, seres que não "desistiram". Tchékhov constrói assim um teatro vivo, que dialoga com leitores/espectadores até os dias de hoje. Se algumas encenações de suas peças tornam-se um "teatro morto", segundo o conceito difundido por Peter Brook ${ }^{13}$ (1925-), o "erro" certamente não está na dramaturgia inovadora de Tchékhov.

Como atriz, também me instigava a dificuldade em se interpretar as personagens tchekhovianas. Em uma disciplina prática do terceiro ano da graduação, lembro-me do Professor Dr. Marcio Aurelio Pires de Almeida, mestre com quem tive a oportunidade de trabalhar, comentando o desafio que se apresenta ao ator: a pluralidade de emoções presentes na cena tchekhoviana, os conflitos internos amontoados em diferentes camadas, o jogo complexo entre as personagens e ainda, a passagem do tempo como um dos protagonistas das obras.

Após a graduação na Unicamp e um ano de estudos na Inglaterra, participei como atriz do espetáculo Rumores... (2003), dirigido por Fernando Faria em São Paulo e que reunia três peças curtas de Samuel Beckett (1906-1989): Comédia (1963), Eu não (1972) e Esboço para teatro I (1959), sendo que desta última também realizei a tradução.

O trabalho com o universo beckettiano em que a incomunicabilidade é tema constante e especialmente nas duas primeiras obras citadas é levado às últimas consequências, instigoume a pesquisar obras da dramaturgia anterior a Beckett onde este problema era inaugurado. Encontrei-me novamente com Tchékhov, desta vez através do autor irlandês, e para minha surpresa Vladimir e Estragon tornaram-se estranhamente próximos de Olga, Macha e Irina; a boca incansável e a orelha presentes em Eu Não pareciam anéis distantes da mesma espiral que envolvia os monólogos superpostos de Andrei e o funcionário surdo Ferapont; Godot, a quem tanto se esperava, talvez estivesse mesmo em Moscou...

\footnotetext{
${ }^{13} \mathrm{Um}$ dos mais importantes diretores de teatro da atualidade, iniciou sua carreira nos anos quarenta em Londres, sua cidade natal. É célebre sua montagem de O jardim das cerejeiras (1981), no revolucionário Théâtre des Bouffes $d u$ Nord, sede de sua companhia em Paris. Sobre o conceito de "teatro morto", ver especialmente The empty space (1991).
} 
$\mathrm{Na}$ conferência Uma palavra sobre Tchékhov, o grande encenador russo Adolf Shapiro $^{14}$ assim expressou a aproximação direta entre Anton Tchékhov e Samuel Beckett, dois grandes inovadores da dramaturgia do século XX:

Se me pedissem para representar graficamente a história do teatro do século $\mathrm{XX}$, eu faria um desenho de três mulheres juntas $v i s-\grave{a}-v i s$ a dois homens em uma lata de lixo. Há uma conexão direta e contínua entre a imagem das três irmãs e a dos vagabundos de Beckett (SHAPIRO, 2010, p. 131).

Ainda em 2003 tive a oportunidade de realizar o workshop "A gramática do ator e diretor: análise ativa e método das ações físicas de K. Stanislávski", ministrado pela Prof. Dra. Nair D'Agostini. Especialista no "sistema" Stanislávski ${ }^{15}$, com estudos realizados na Rússia com Gueórgui Tovstonógov ${ }^{16}$ (1913-1988), discípulo direto de Stanislávski (18631938), e com o professor assistente Arkádi Kátsman ${ }^{17}$ (1921-1989), Nair conduziu um trabalho teórico-prático a partir do conto A feiticeira (1886), de A. Tchékhov. O workshop proporcionou o diálogo direto entre o "sistema" Stanislávski, continuamente aperfeiçoado pelo diretor até os últimos dias de vida e a literatura inovadora de Tchékhov. A parceria entre o autor e o Teatro de Arte de Moscou (TAM), fundado por Stanislávski e NemiróvitchDântchenko $^{18}$ (1858-1943), apesar das divergências, foi extremamente fértil. Estes compreenderam efetivamente as inovações propostas por Tchékhov e as encenações do TAM tornaram-se referência para as artes cênicas do século XX, influenciando inúmeros atores e diretores.

O trabalho com Nair D'Agostini também me apresentou o universo de outros artistas russos, como o cineasta Andrei Tarkóvski ${ }^{19}$ (1932-1986) e inspirou a realização de minha

\footnotetext{
${ }^{14}$ Adolf Shapiro, ganhador do Prêmio Internacional Stanislávski é reconhecido internacionalmente como um dos mais importantes encenadores das peças de Tchékhov e um dos maiores diretores russos vivos. Há mais de trinta anos desenvolve sua metodologia de trabalho a partir dos ensinamentos de Stanislávski e sua discípula, Maria Knébel.

${ }^{15}$ Konstantin Serguêievitch Alekséiev mais conhecido por Konstantin Stanislávski, foi ator diretor, pedagogo e escritor russo, um dos fundadores, junto com Vladímir Nemiróvitch-Dântchenko, do Teatro de Arte de Moscou (TAM). O "sistema" Stanislávski, impulsionado pelo projeto do TAM de renovação da arte teatral em todos os âmbitos, é o resultado da experimentação prática contínua de Stanislávski, que sistematizou e teorizou sobre os procedimentos artísticos seus e de seus atores, baseado na indissolúvel unidade física e psíquica.

${ }^{16}$ Grande diretor russo, discípulo da tradição stanislavskiana, considerado internacionalmente como um dos maiores nomes da encenação do século XX. Seus espetáculos viajaram a Europa, América e Ásia e somam mais de uma centena. Como pedagogo, foi responsável pela formação de grandes talentos russos da cena contemporânea.

${ }^{17}$ Ator, diretor e pedagogo russo, assistente de Gueórgui Tovstonógov.

${ }^{18}$ Vladímir Ivánovitch Nemiróvitch-Dântchenko, diretor de teatro, escritor e dramaturgo. Fundou em 1898, com Stanislávski, o Teatro de Arte de Moscou.

${ }^{19}$ Filho do poeta Arséni Tarkóvski, é considerado um dos maiores cineastas russos de todos os tempos. Dentre seus filmes, que se caracterizam por um profundo sentido espiritual, estão Andrei Rubliov (1966), O espelho
} 
pesquisa no mestrado no programa de Literatura e Cultura Russa. O cinema de Tarkóvski, que aposta na força e beleza das imagens, sem apoiar-se em um roteiro de acontecimentos lineares e no qual a música está em diálogo permanente com a cena, evoca fortemente a dramaturgia tchekhoviana. $\mathrm{Na}$ imaterialidade da luz e sombra, nas palavras, ruídos, silêncios e sons, Tarkóvski, assim como o fazia Tchékhov na concretude e no "invisível" da cena teatral, esculpe o próprio tempo.

Quando ingressei no Núcleo experimental do Teatro Popular do Sesi, coordenado por Isabel Setti, em 2004, tive novamente a oportunidade de mergulhar, de maneira prática, no universo tchekhoviano. A diretora e pedagoga pedira a cada um dos atores que escolhesse um pequeno texto sobre o qual trabalharíamos durante todo o ano. Tínhamos um espaço aberto para a investigação, onde o tempo era nosso aliado e as dificuldades bem-vindas - minha escolha foi o monólogo inicial de Olga em As três irmãs (1900). O trabalho resultou em uma pequena cena apresentada dentro do Núcleo no ano seguinte e estimulou a continuação da pesquisa de maneira mais profunda, também no âmbito teórico.

Em 2007 entrei em contato com a dramaturgia de um dos maiores autores israelenses, Hanoch Levin (1943-1999), e com uma de suas obras-primas - Réquiem (1999), inspirada em três contos de A. Tchékhov - Angústia (1885), O violino de Rotschild (1894) e No fundo do barranco (1900).

Filho de emigrantes poloneses sobreviventes do Holocausto, Hanoch Levin é referência obrigatória no panorama teatral e literário de Israel e reconhecido mundialmente como um dos artistas mais inquietantes da literatura e da cena contemporâneas. Além de romances, poesias e canções, escreveu mais de sessenta peças, muitas das quais também dirigiu, sempre com o rigor e a ousadia que foram sua marca.

Junto com Dinah Feldman realizei a idealização e produção do espetáculo Réquiem, dirigido por outro grande mestre, Francisco Medeiros. Realizei também a tradução do texto em parceria com Dinah Feldman, Francisco Medeiros, Lilian Froiman e Pablo Ferreira, além de participar do espetáculo como atriz. O projeto foi um dos vencedores do II Concurso Centro da Cultura Judaica de Montagens Teatrais (2007), estreando em janeiro de 2009 a obra de Levin no Brasil e tem nos dado belos frutos até os dias de hoje.

O texto de Levin, que dialoga livremente com a obra tchekhoviana, salientando sua Humanidade ao mesmo tempo em que preserva a forte assinatura do autor israelense, nos

(1974), Stálker (1979) e O sacrificio (1986). Aborda suas experiências com o cinema no livro Esculpir o tempo (2002). 
possibilita a investigação na cena, da riqueza das imagens propostas por Tchékhov, alinhavadas pelo tema da incomunicabilidade que perpassa toda a peça. Levin combina com maestria diálogos profundamente líricos com momentos narrativos, conduzidos por personagens sem nome, mas que carregam sentidos arquetípicos, como o Velho, a Mãe, a Prostituta. Assim como em Tchékhov, os momentos cômicos se amalgamam com momentos trágicos, em uma obra que não nega nem afirma, mas questiona o sentido da vida e da morte.

Entre os meses de setembro e novembro de 2010, em comemoração aos cento e cinquenta anos de nascimento de A. Tchékhov, a Fundação Nacional de Artes (FUNARTE) em parceria com o Festival Internacional de Teatro A. Tchékhov de Moscou realizou um grande evento em sua sede em São Paulo, o Espaço Tchékhov 2010, com curadoria da orientadora desta pesquisa, Prof. Dra. Elena Vássina. Tive a oportunidade de participar como atriz de uma experiência que se tornou fundamental a este estudo, por desvendar na prática da cena, elementos que se destacavam nas análises teóricas.

Adolf Shapiro, um dos encenadores mais importantes da atualidade, discípulo de Maria Knébel ${ }^{20}$ (1898-1995), fora convidado pelo evento a dirigir um estudo cênico a partir das obras dramáticas de A. Tchékhov, junto à mundana cia., coletivo de atores que já se destacava no cenário teatral brasileiro principalmente por sua montagem de O idiota - uma novela teatral (2010), baseada na obra de Dostoiévski (1821-1891) e dirigida por Cibele Forjaz.

O diretor escolheu realizar um ato de cada uma das quatro principais peças de Tchékhov - o primeiro ato de $A$ gaivota, o segundo de $O$ tio Vânia (1897), o terceiro de $O$ jardim das cerejeiras (1904) e o quarto ato de As três irmãs, respectivamente. O trabalho resultou em Tchékhov ${ }^{4}$ - um estudo cênico, apresentado no Complexo Cultural Funarte, ocupando diversas salas do mesmo.

Apesar do curto tempo de ensaio - pouco mais de três semanas - o estudo conduzido por Shapiro foi extremamente valioso. Os primeiros encontros foram dedicados à análise das peças, quando o diretor apresentou o contexto em que Tchékhov escrevera cada uma delas, esclarecendo as complexas relações entre as personagens, seus conflitos internos e as diferenças entre o que muitas vezes diziam e o que realmente sentiam/desejavam/pensavam. Shapiro mostrou que os problemas de comunicação entre as personagens, análise que até então eu desenvolvia no âmbito teórico, eram fundamentais à cena enquanto prática - os

\footnotetext{
${ }^{20}$ Aluna de Stanislávski e atriz do Teatro de Arte de Moscou. Pedagoga, diretora e autora de inúmeras obras sobre o "sistema" Stanislávski.
} 
atores deveriam estar conscientes destes problemas, instaurados por Tchékhov ao alterar o paradigma da ação, conflito e diálogo. O texto tchekhoviano, como nos revelou tão claramente o diretor, não se constitui apenas dos diálogos entre as personagens e das rubricas do autor, mas sim, do conjunto que estes formam com as camadas dos conflitos internos, distribuídos sob as réplicas em diferentes profundidades. Sem estas camadas o teatro de Tchékhov não existe, é morto. Apesar de não se manifestarem no diálogo, de serem "indizíveis", "invisíveis", podem ser a chave para a compreensão de suas obras.

Ainda que se restrinja ao âmbito teórico, a pesquisa esteve sempre em conexão com a prática da cena. Os exemplos que se seguem na dissertação, tanto dos trabalhos mencionados acima, como também de filmes e diversas encenações das peças de Tchékhov, visam não somente ilustrar as análises expostas, mas principalmente fomentar o diálogo entre as reflexões teóricas e a prática teatral.

Estabeleceu-se como objetivo geral da dissertação, elucidar, através de uma análise dos processos comunicativos entre as personagens de $A$ gaivota, O tio Vânia, As três irmãs e O jardim das cerejeiras, a criação de um novo paradigma artístico no sistema dramático de A. Tchékhov.

Para tanto, as análises retomam a discussão da posição incomum do autor no contexto literário russo em fins do século XIX, discutindo as principais transformações em curso na sociedade russa da época. Ainda no primeiro capítulo, pretende-se demonstrar como estas transformações se descortinam na poética dramática tchekhoviana, revelando-se nos problemas de comunicação entre as personagens.

O segundo capítulo aborda as inovações do sistema dramático de Tchékhov, relacionado-as com a teoria dos gêneros literários, principalmente com duas de suas obras clássicas, a Poética de Aristóteles e a Estética de G.W.F. Hegel. Estudos que problematizam esta teoria, como Temática (1973) de Boris V. Tomachévski (1890-1957) e Epos e romance (1993) de Mikhail Bakhtin (1895-1975), além de Teoria do drama moderno [1880-1950] (2001) de Peter Szondi (1929-1971) e no âmbito acadêmico brasileiro Teatro épico (2010) de Anatol Rosenfeld (1912-1973), também alicerçam as análises, pois ao estabelecerem o diálogo entre a literatura dramática e suas respectivas épocas, colocam em questão a própria teoria dos gêneros.

A análise da articulação entre os problemas de comunicação e a cena tchekhoviana dáse no terceiro capítulo, em que se pretende compreender a importância dos objetos, espaços, 
sons, ruídos e silêncios indicados nas rubricas, além do subtexto; todos estes elementos atuam junto aos diálogos para que nasça o "invisível" e o "indizível", sem os quais a cena tchekhoviana não se completa. Também neste capítulo, são discutidas algumas peculiaridades do diálogo nas quatro peças estudadas, sempre em relação aos problemas de comunicação entre as personagens.

Quanto à bibliografia que fundamenta a pesquisa, graças à reserva técnica proporcionada pela bolsa Fapesp, foi possível priorizar da extensa lista de publicações referentes às obras dramáticas de Tchékhov, títulos russos que se tornaram clássicos nos estudos tchekhovianos, além de publicações internacionais mais recentes, por enquanto ainda inéditas em nosso país. Dentre as primeiras, destaca-se Chekhov's poetics (1983), obra de referência tanto para as pesquisas sobre o drama quanto sobre a prosa tchekhoviana, de A. P. Tchudakhov, um dos maiores especialistas russos na literatura de Tchékhov; Vladímir Katáiev, professor de Literatura Russa na Universidade de Moscou Lomonóssov e chefe da Comissão Tchékhov da Academia Russa de Ciências, é outro pesquisador de destaque, tendo publicado inúmeros livros e artigos sobre a poética tchekhoviana. Sua obra If only we could know!: an interpretation of Chekhov (2002) apresenta estudos de obras em prosa e também de cinco das peças de Tchékhov.

Dentre as publicações internacionais, realçamos The polemical force of Chekhovian comedies: a rhetorical analysis (2007) de John McKellor Reid, pesquisador inglês, professor da Universidade do Oeste da Inglaterra, Bristol; Seeing Chekhov: life and art (2005) de Michael C. Finke, especialista em literatura russa na Universidade de Washingston; Aspects of dramatic communication: action, non-action, interaction: A. Chekhov, A. Blok, D. Charms (1992) de Jenny Stelleman, da Universidade de Amsterdam.

Somam-se às publicações mencionadas acima títulos já conhecidos que se tornaram obrigatórios aos estudos tchekhovianos, também inéditos no Brasil, como The Chekhov play: a new interpretation (1985), do tradutor e pesquisador inglês Harvey Pitcher; Chekhov and the evolution of his art (1975) e Anton Chekhov: a life (1998), do especialista em literatura russa Donald Rayfield; e Chekhov: a spirit set free (1988), de V. S. Pritchett, crítico, biógrafo e novelista.

Também essenciais às nossas análises foram os filmes russos baseados em textos dramáticos de Tchékhov, como O tio Vânia (1971), dirigido por Andrei Konchalóvski, e os registros de encenações das obras de Tchékhov de diretores contemporâneos, como A gaivota 
(2001) encenada por Liév Dódin ${ }^{21}$ e As três irmãs (2004) por Piotr Fomenko ${ }^{22}$, assim como encenações que se tornaram marcos do teatro do século XX: As três irmãs (1984) dirigida por Peter Stein e O jardim das cerejeiras nas versões de Giorgio Strehler ${ }^{23}$ (1974) e Peter Brook (1981).

Para concluir, gostaríamos de observar que as muitas notas de rodapé, presentes desde esta introdução, visam facilitar o acesso da pesquisa a múltiplos leitores. As traduções, quando não indicadas, são de nossa autoria.

\footnotetext{
${ }^{21}$ Encenador russo de destaque, diretor do Teatro Mali de São Petersburgo.

${ }^{22}$ Um dos mais importantes encenadores russos da atualidade, Piotr Fomenko é diretor artístico das oficinas que levam seu nome. Dirigiu mais de cinquenta espetáculos teatrais, além de filmes e episódios para a televisão.

${ }^{23}$ Diretor de teatro e ópera, fundou com Paolo Grassi o Piccolo Teatro di Milano. De Tchékhov dirigiu duas encenações de O jardim das cerejeiras (em 1955 e 1974), além de uma montagem em 1959 de Platónov, um dos primeiros textos teatrais do autor, escrito em 1878 e publicado somente em 1923. Também conhecido como Peça sem nome.
} 


\title{
UM AUTOR DE INTERROGAÇÕES E RETICÊNCIAS
}

\author{
A arte é eternamente livre. A arte foge diante dos \\ imperativos, como o dia diante da noite.
}

Vassíli Kandínski ${ }^{24}$

Tchékhov foi um artista que em toda sua carreira literária preocupou-se não em responder, mas em fazer perguntas. Constantemente encontramos em suas peças e contos personagens que ao invés de agir, se questionam: "Que fazer?", "E então?"; as respostas que se apresentam nunca são conclusivas ou pontuais, mas ao contrário, suscitam novas interrogações. Na tentativa de respondê-las, as personagens lançam opiniões diversas, por vezes opostas, para as quais Tchékhov dá igual peso e importância, sem favorecer nenhuma delas; em outros casos, as respostas constituem-se apenas de silêncio e reticências, que ao invés de emudecerem tais perguntas, as eternizam. Em uma época e sociedade que ainda privilegiavam respostas, Tchékhov teve a coragem de fundamentar sua poética em interrogações e reticências.

Em carta ao editor Suvórin ${ }^{25}$ (1834-1912), em outubro de 1888, o autor já ressaltava que o dever de um escritor não era resolver, mas justamente saber colocar um problema:

Ao exigir de um artista uma atitude consciente para com o seu trabalho, você está certo, mas está misturando dois conceitos: a solução do problema e a colocação correta do problema. Só o segundo é obrigação do artista (TCHÉKHOV, 2002a, p. 91, grifo do autor).

$\mathrm{Na}$ vasta correspondência trocada com o editor, Tchékhov incansavelmente defendeu ao artista uma posição imparcial, incomum para o contexto russo da época. Para o autor, não caberia ao artista julgar, mas apenas testemunhar:

Eu acho que não são os escritores que devem resolver questões como Deus, o pessimismo etc. O que cabe ao escritor é apenas representar quem, quando e em que circunstância falou ou pensou sobre Deus ou sobre o pessimismo. O artista não deve ser juiz de suas personagens e daquilo que dizem, mas tão somente testemunha imparcial. Ouvi dois russos falarem sobre pessimismo,

\footnotetext{
${ }^{24} 1996$, p. 81.

${ }^{25}$ Aleksei Sierguêievitch Suvórin, jornalista, crítico teatral, editor e escritor. Era diretor do jornal Nóvoe Vriémia (Novo Tempo) de tendência conservadora e de grande circulação e influência, que publicou muitos dos contos de A. Tchékhov.
} 
numa conversa sem nexo e que não chegava a nada. Devo transmitir essa conversa exatamente como a ouvi; a julgá-la serão os jurados, ou seja, os leitores. Meu papel é apenas o de ter talento, ou seja, de saber diferenciar os testemunhos importantes dos inúteis, de saber iluminar as personagens e falar a língua delas (TCHÉKHOV, 2002a, p. 52-53).

A ausência de julgamentos e imposição de ideias, além do inacabamento das obras, reafirmavam a confiança que Tchékhov depositava em seu público, estabelecendo com ele um diálogo direto:

Você [o editor Suvórin] me repreende pela objetividade, chamando-a de indiferença para com o bem e o mal, de ausência de ideais e de ideias etc. Você quer que, ao representar ladrões de cavalos, eu diga: roubar cavalos é um mal. Mas isso, mesmo sem que o diga, já é sabido de longa data. Deixemos aos jurados julgá-los, a minha função é apenas mostrar como eles são. [...] Quando escrevo, eu confio inteiramente no leitor, supondo que ele mesmo acrescentará os elementos subjetivos que faltam ao conto (TCHÉKHOV, 2002a, p. 296).

A objetividade imparcial do artista e a concisão defendida por Tchékhov não foram aceitas de imediato. Em uma época em que muitas obras literárias tornavam-se meios para a propagação de ideologias (lembremo-nos do fenômeno resultante da obra Que fazer? de Tchernichévski $^{26}$ [1863]), a recusa inflexível de Tchékhov em doutrinar, seja no plano político, filosófico ou moral, rendeu-lhe duras críticas. O caráter interrogativo, a brevidade e os finais reticentes, tanto de seus contos como de suas obras dramáticas, foram inovações que chocaram os leitores/espectadores da época e certamente contribuíram para o fracasso das estreias das primeiras obras dramáticas de Anton Pávlovitch.

Em 1896 no Teatro Alexandrínski em São Petersburgo, o fracasso da estreia de $A$ gaivota fora tão estrondoso que Tchékhov prometera nunca mais escrever para o teatro. $\mathrm{O}$ autor, no entanto, tinha plena consciência da nova proposta contida na dramaturgia da obra e por consequência, do risco que corria, já que admitia que "o público realmente gosta na arte daquilo que é banal e há muito familiar, aquilo com que eles se acostumaram"27.

$\mathrm{O}$ que os espectadores veriam no palco na noite de estreia de A gaivota estava longe das estruturas aristotelicamente encadeadas dos textos clássicos, dramas românticos,

\footnotetext{
${ }^{26}$ Nikolai Gavrílovitch Tchernichévski (1828-1889), filósofo, economista e crítico russo, foi o líder do movimento revolucionário democrático na década de 1860, em luta contra o tzarismo. Sua obra Que Fazer? escrita quando ele se encontrava preso em São Petersburgo, tornou-se a bíblia da juventude revolucionária da época. Extremamente doutrinária, a obra defende a igualdade e a criação de um "novo homem russo", que através da auto-disciplina venceria a melancolia e a passividade.

${ }^{27}$ CHEKHOV, A. Note-book of Anton Chekhov. Trad. S. S. Koteliansky e Leonard Woolf. Disponível em: http://www. gutenberg.net/1/2/4/9/12/12494, p. 25. Acesso: 10 abr. 2009.
} 
comédias de costume, vaudevilles e farsas, aos quais estavam acostumados. Também o ritmo proposto por Tchékhov - "[...] comecei-a forte e terminei em pianíssimo" (apud ANGELIDES, 1995, p. 192) - contradizia as regras da dramaturgia tradicional, que demandavam um andamento crescente, rumo ao clímax e desenlace da peça. Por fim, a ausência de heróis ou heroínas que "costurassem" toda a obra através de uma linha de ação ininterrupta e que possibilitasse a interpretação marcante dos grandes atores e atrizes da época contribuiu para a desaprovação total dos espectadores.

Instaurava-se, portanto, um paradoxo - se por um lado o público tentava decifrar a obra segundo cânones antigos, por outro, o autor não dava a este "a informação de que ele tinha necessidade e para a percepção da qual estava preparado" (LOTMAN, 1978b, p. 61). As situações cotidianas e os diálogos pronunciados em linguagem comum e tom conversacional soavam monótonos e desprovidos de caráter artístico; a falta de grandes acontecimentos era incomum e perturbadora; a ação interior, que deveria revelar ao público os pensamentos, desejos e emoções das personagens, guiando e conduzindo os espectadores através do mundo fíctício da peça, não foi capaz de substituir a unidade de ação a qual estavam acostumados. E a classificação dada por Tchékhov à obra - uma comédia em quatro atos - confundiu ainda mais o público da estreia de $A$ gaivota.

Habituados às peças curtas cômicas que o próprio autor escrevia com grande sucesso, além dos contos, muitos deles publicados em revistas humorísticas e pelos quais Tchékhov já era um autor consagrado, o público definitivamente não pôde compreender uma comédia que não suscitava o riso, em que a intriga estava ausente e com um suicídio no suposto desenlace feliz. F. A. Korch, proprietário-fundador do Teatro Dramático Russo, conhecido em Moscou como Teatro Korch, que além de um repertório de apelo popular produziu na Rússia as estreias de $A$ casa de bonecas (1879) e $O$ inimigo do povo (1882) de Ibsen, e o próprio Ivánov $^{28}$ (1887) de Tchékhov, teria dito a este após uma leitura de $A$ gaivota: "Meu querido, isso não é apropriado para o palco: você faz uma pessoa se matar com um tiro atrás do palco e nem permite que ela fale antes de morrer!" (apud T. L. SCHIÉPKINA-KUPIÉRNIK, 1986, p. 247).

Os motivos de Tchékhov em classificar tanto A gaivota como O jardim das cerejeiras como comédias envolvem certa polêmica, principalmente por suas críticas às encenações posteriores do Teatro de Arte de Moscou, que considerava "lacrimosas". De qualquer maneira, fica claro que ao denominar as referidas peças como comédias, o autor queria

\footnotetext{
${ }^{28}$ Uma das primeiras peças de Tchékhov, estreou em novembro de 1887 e foi considerada, depois de três apresentações, um fracasso.
} 
reforçar o aspecto prosaico das obras, em que eram retratadas pessoas comuns, em situações cotidianas. Para Donald Rayfield (1975, p. 97), comédia significava para Tchékhov o oposto de tragédia; sugeria que a morte ou a supressão da personagem central não impediria a vida de seguir seu curso normal.

Cabe lembrar, como ressalta Rubens Figueiredo (2004, p. 104) no posfácio de sua tradução de $A$ gaivota, do contexto da estreia da peça em São Petersburgo. A maior parte da plateia era formada por admiradores da atriz cômica Levkêieva, que seria homenageada por uma comédia logo após a obra de Tchékhov. O público, ávido para rir de suas personagens burlescas, provavelmente esperava algo similar da comédia de Tchékhov.

Dois anos após a malograda estreia em São Petersburgo, Konstantin Stanislávski e Vladímir Nemiróvitch-Dântchenko conseguem (depois de muita insistência) convencer o autor e estreiam A gaivota em Moscou. O sucesso da montagem do Teatro de Arte, cujo símbolo até os dias de hoje é a gaivota, presente no pano de boca do teatro, deve-se certamente à percepção dos diretores da relação direta e estreita entre as personagens e a plateia - retratadas em ações cotidianas, simples, as personagens de Tchékhov são um espelho do próprio público. Neste sentido, o depoimento de Nemiróvitch-Dântchenko em carta a Stanislávski também atesta a importância de uma nova dramaturgia: "Novas peças atraem público em todos os lugares porque ele descobre nelas respostas novas para os problemas da vida" (apud TAKEDA, 2003, p. 63).

Desta forma, o público moscovita teve a oportunidade de reconhecer-se por completo nos pensamentos, desejos, anseios e insatisfações das personagens, detalhadamente concretizados pelos atores dirigidos por Stanislávski (incluindo-se o mesmo, também intérprete). $\mathrm{O}$ alto grau de memória comum partilhado entre personagens e espectadores era algo novo, contagiante. Se até então o palco era tomado por grandes acontecimentos, distanciados do espectador pela interpretação de atores comprometidos com o estrelato, a dramaturgia de Tchékhov inaugurava na Rússia o drama de indivíduos comuns, que embora sufocados por uma realidade apática, eram impulsionados por um apaixonado desejo de viver. Privilegiando o ensemble ao destaque de interpretações individuais e compreendendo a nova natureza do conflito dramático tchekhoviano, a importância do subtexto - do que está "além" das palavras pronunciadas pelas personagens - a encenação de Stanislávski contribuiu decisivamente para o sucesso da comunicação entre autor e público.

Ao contrário do que acontecia com a plateia do repertório teatral vigente na época, os espectadores das peças de Tchékhov não eram levados a julgar as personagens, mas antes, "convidados a responder em um nível emocional aos sentimentos que as personagens 
experimentavam" (PITCHER, 1985, p. 9). Tchékhov instaura, por assim dizer, um campo elétrico entre palco e plateia, espaço "entre" altamente fértil, no qual espectadores, atores e autor, compartilham a mesma experiência.

Tempo de transição e incertezas ou "Neste mundo não se compreende nada"

Embora o talento de Tchékhov como autor de contos e peças teatrais tenha sido reconhecido em vida, A. P. Tchudakhov nota nas críticas da época um tom negativo e mesmo didático, determinado justamente pela natureza inovadora do sistema artístico tchekhoviano e pela consciência gradual que os críticos adquiriam da ruptura empreendida pelo autor com a tradição literária. Segundo o especialista russo:

os críticos interpretavam as inovações de Tchékhov ou como a herança de um passado cômico que deveria ser superado, uma habilidade literária deficitária, ou como uma ruptura consciente das regras literárias generalizadamente aceitas (CHUDAKHOV, 1983, p. 133).

É justamente por esta não-adequação e não-aderência às "regras artísticas", que Tchékhov foi considerado não somente em relação aos grandes autores da época, mas também em relação aos autores de sua geração, um artista inferior. Sua objetividade era vista por parte da crítica como "sangue frio"; a habilidade em transformar detalhes em metáforas, reduzida a "pormenores inúteis"; a liberdade de uma escrita que não se amarrava em relações de causa e efeito, tida como "fragmentária", "frouxa". Em uma época de constantes incertezas, boa parte do público e da crítica ansiavam por respostas claras, as quais não encontravam nas obras de Anton Tchékhov.

No ensaio Escritores russos, censores e leitores ${ }^{29}$ (1981) Vladímir Nabókov esclarece as duas forças contra as quais os grandes autores russos do século XIX tiveram de lutar. De um lado estava o governo tzarista e a censura por ele instaurada; do outro, encontrava-se a crítica não governamental, utilitária, radical, preocupada exclusivamente com o bem estar do povo. Para Nabókov, estes críticos "incorruptíveis, heroicos, indiferentes às privações do exílio, mas também às belezas da arte" (NABOKOV, 1981, p. 4), consideravam a literatura, a ciência e a filosofia apenas como meios para melhorar a situação social e econômica dos

\footnotetext{
${ }^{29}$ Publicado em Lectures on Russian literature.
} 
desfavorecidos, para alterar a estrutura política do país. Apesar de suas virtudes, para as artes, eram tão prejudiciais quanto o governo. Ainda segundo Nabókov:

Os críticos radicais lutavam contra o despotismo, mas desenvolveram um despotismo próprio. As demandas e exigências, as teorias que tentavam instaurar eram elas mesmas tão irrelevantes à arte quanto o convencionalismo da administração. [...] Na opinião dos tzares os autores deveriam servir ao estado, na opinião dos críticos radicais os escritores deveriam servir às massas" (NABOKOV, 1981, p. 5).

Tchékhov indignava-se com o estilo profético assumido pelo circuito literário na segunda metade do século XIX e afirmava que admitir-se ignorante consistia em um progresso muito maior:

Já está na hora de as pessoas que escrevem, e principalmente os artistas, compenetrarem-se de que neste mundo não se compreende nada, como outrora reconheceu Sócrates e como Voltaire reconhecia. A turba acha que compreende tudo e que sabe tudo; e, quanto mais estúpida ela é, mais amplo lhe parece o seu horizonte. Se um artista, em quem a multidão acredita, tomar a decisão de declarar que ele não compreende nada do que vê, só isto já constituirá um grande saber no domínio do pensamento e um grande passo à frente (TCHÉKHOV, 2002a, p. 53).

$\mathrm{O}$ autor ainda temia àqueles que procuravam em suas obras tendências políticas ou morais de qualquer tipo e defendia com ardor a liberdade e o talento do artista:

Se lhe servem café, não o tome por cerveja. Se lhe apresento os pensamentos de um professor, acredite em mim e não procure neles o pensamento de Tchékhov (TCHÉKHOV, 2002a, p. 228).

[...] Tenho medo daqueles que procuram nas entrelinhas uma tendência e querem me ver necessariamente como liberal ou conservador. Não sou nem liberal, nem conservador, nem reformista, nem monge, nem indiferencista. Eu queria ser um artista livre - apenas isto, e lamento a Deus que não me tenha dado forças para sê-lo. Detesto a mentira e a violência em todas as suas formas. [...] Considero as marcas e os rótulos um preconceito. Meu santuário são o corpo humano, a saúde, a inteligência, o talento, a inspiração, o amor e a liberdade absoluta, liberdade ante a violência e a mentira, onde quer que estas se manifestem. Este é o programa que eu seguiria, se fosse um grande artista (apud ANGELIDES, 1995, p. 99).

A posição não engajada de Tchékhov, um artista que se recusava a impor ideias, reflete-se nas próprias inovações de sua poética. As personagens afastam-se dos rótulos e marcas e deixam transparecer um sem fim de contradições, de onde nasce o conflito, não mais 
polarizado em antagonistas que lutam diretamente; situado no interior de cada personagem, o conflito manifesta-se na relação entre cada uma delas e na realidade em que vivem, sem nunca se resolver, como na própria vida. A paleta de Tchékhov compõe-se assim, de infinitas gradações, dada a pluralidade de pontos de vista que o autor abarca, já que a verdade nunca é uma só. Se sua época buscava respostas em tons claramente definidos, que ao longo do tempo emudeceram, Tchékhov traçava perguntas que passaram a dialogar com o eterno.

Por certo, a massa de respostas profeticamente dada pelos críticos radicais em diversas obras, configura-se como uma tentativa de solucionar os numerosos problemas e as profundas inquietações que marcavam a sociedade russa da época.

Pressionado pela derrota na guerra da Crimeia (1853-1856), o tzar Alexandre II $^{30}$ (1818-1881), a partir dos anos 1860, empreendeu uma série de reformas que visavam a modernização do país, que se encontrava em um descompasso histórico com as potências capitalistas da Europa.

A primeira grande medida foi o decreto de fevereiro de 1861 que extinguia a servidão, regime que organizava as relações da grande maioria da população russa, habitante de áreas agrárias. Em fins do século XIX, de acordo com o historiador Daniel Aarão Reis Filho (2003, p. 19), $85 \%$ da população russa vivia no campo. A libertação dos camponeses, contudo, foi realizada em um processo que garantia os interesses dos senhores de almas, uma vez que os ex-servos eram vítimas de uma alta tributação e tiveram de pagar em dezenas de prestações ao estado, que ressarciu os nobres, as terras que coletivamente ocuparam. $\mathrm{O}$ fim da servidão não aboliu os problemas relacionados à terra, mas acirrou as tensões já existentes.

Tchékhov conhecia de perto essa realidade, vindo de uma família de ex-servos - seu avô havia comprado por três mil e quinhentos rublos a própria liberdade e a da família, vinte anos antes do decreto do tzar. O trabalho exaustivo no campo, vivenciado na infância, ficara para sempre marcado na memória do autor:

Quando eu era criança e vivia com meu avô na propriedade do conde Plátov, tive que passar jornadas inteiras, de sol a sol, cuidando da máquina e anotando as libras e os puds ${ }^{31}$ de grão batido. Os silvos, os arquejos, os roncos da máquina, surdos como os de um pião, que se fazem ouvir no mais duro da lida, o ranger das rodas, o andar preguiçoso dos bois, as nuvens de fumaça, os rostos suados e negros de quase cinquenta homens - tudo isso ficou gravado na minha memória, como o Padre-nosso (TCHÉKHOV, 2002a, p. 57).

\footnotetext{
${ }^{30}$ Filho e sucessor de Nicolau I, ascendeu ao governou russo durante a guerra da Crimeia em 1855 e reinou até 1881, quando foi assassinado.

${ }^{31}$ Antiga medida equivalente a $16,3 \mathrm{~kg}$ (N. do T.).
} 
A brutal tributação sobre os camponeses no processo de abolição da servidão garantiu a exportação de "excedentes" agrícolas, o que por sua vez, financiou o desenvolvimento da indústria em solo russo. Ao custo da fome da própria população, em fins do século XIX a Rússia já se tornava um país cujo crescimento econômico era mesmo liderado pela indústria, aberta ao investimento de nações estrangeiras, o que provocou a insatisfação da burguesia nacional. Se por um lado o processo de modernização trazia a Rússia para junto das grandes nações europeias, incitando o crescimento urbano, por outro agravava as já acentuadas desigualdades sociais - os camponeses, apesar de libertos da condição de servos, ainda continuavam como cidadãos "inferiores" e os operários sofriam com as péssimas condições de vida e salários ínfimos.

As reformas do governo de Alexandre II, que incluíram o afrouxamento parcial da censura, irritaram as alas mais conservadoras da sociedade e paradoxalmente também as alas mais liberais, que as consideraram demasiado moderadas. Fortaleceram-se os movimentos políticos radicais, que exigiam mudanças profundas na sociedade. $\mathrm{O}$ fato é que o processo de modernização empreendido pelo tzar ignorou a miséria em que vivia a maioria da população; desconheceu, ainda, a corrupção desmesurada dos mais de quinhentos mil burocratas do estado; a degradação do homem e a pobreza extrema não se alteraram. Neste sentido, o crítico literário Roberto Schwarz (1938-) nota as semelhanças entre Rússia e Brasil do século XIX: "Também na Rússia a modernização se perdia na imensidão do território e da inércia social, entrava em choque com a instituição servil e com seus restos. O progresso é uma desgraça e o atraso uma vergonha" (SCHWARZ, 2009, p. 27-28).

As contradições profundas do processo de modernização russo foram abordadas por Tchékhov mais especialmente em $O$ jardim das cerejeiras, como analisaremos a seguir. Escrita lentamente nos quatro últimos anos de vida de Anton Pávlovitch, a obra apresenta a complexidade e ambivalência do progresso, que apesar dos proclamados benefícios, não transforma as condições de vida seculares de desigualdade e ignorância, além de trazer em si a destruição.

A questão também se destaca em $O$ tio Vânia, enfatizada nas falas do médico Ástrov, que conhece de perto a miséria e a ignorância da província, em que a melhoria das condições de vida inexiste e a destruição é causada pela necessidade da sobrevivência:

ÁSTROV: [...] Este mapa apresenta, de modo geral, o quadro da decadência gradual mas incontestável que, segundo me parece, precisa de pouco mais de quinze anos para se tornar completo. A senhora me dirá que isso é decorrência da civilização, que a antiga vida cede necessariamente lugar à 
nova. Sim, eu compreenderia isso, se no lugar das florestas derrubadas tivessem construído estradas e ferrovias, se aqui existissem fábricas, escolas, se o povo tivesse agora mais saúde, fosse mais rico e inteligente, mas não é nada disso! A comarca continua cheia de pântanos, mosquitos e miséria, tifo, difteria, incêndios, e com a mesma falta de estradas. A luta do povo pela sobrevivência - luta que supera suas forças - foi que causou a decadência, e mais a indolência, a ignorância, a falta absoluta de consciência: o camponês trêmulo, faminto e doente, para salvar os destroços de sua vida, para proteger seus filhos, instintivamente, inconscientemente, se agarra a tudo com que pode acalmar a fome e se esquentar, e pouco se incomoda com o amanhã, destrói tudo... Já quase tudo está destruído e nada foi construído em seu lugar [...] (TCHÉKHOV, 1998b, p. 102).

Ástrov indigna-se com a destruição e a ignorância e luta contra elas - cuida de florestas, assim como de doentes. Mas como as contradições são vitais ao teatro de Tchékhov, diante da realidade dura, o médico também se embrutece; pouco a pouco é consumido pela bebida, vê-se sozinho, incompreendido, "um sujeito estranho"; torna-se incapaz de amar, para a angústia da jovem Sonia.

De sua posição independente no cenário político da época, através da dúvida de todas as utopias e do horror a qualquer doutrina, Tchékhov, assim como o doutor Ástrov, sempre se indignou com a ignorância, diagnosticando-a nas diferentes tendências e partidos políticos. Nas cartas trocadas com Suvórin, o editor de inclinações extremamente conservadoras, Tchékhov declarou:

Você escreve que é impossível imaginar nada mais desprezível que a nossa oposição liberal... Ora, mas e aqueles que não estão na oposição? É pouco provável que sejam melhores. A mãe de todos os males russos é a ignorância crassa, e ela se faz presente no mesmo grau em todos os partidos e orientações (TCHÉKHOV, 2002a, p. 235).

Para se construir uma realidade melhor e se extinguir a ignorância, Tchékhov acreditava na importância da justiça e do trabalho:

E é belo o mundo de Deus. Só uma coisa não é: nós. Que falta nos fazem a justiça e a humildade [...]. Em vez de sabedoria, o atrevimento e a maldade, além de qualquer medida; e, em vez de trabalho, a preguiça e a devassidão; de justiça nem falar, e o conceito de honra não vai além do "orgulho do uniforme", uniforme esse que serve de enfeite vergonhoso em nossos bancos de acusados. O que é preciso mesmo é trabalhar, o resto que vá para o inferno. E o principal é ser justo - o resto vem por conta (TCHÉKHOV, 2002a, p. 321). 
Mas como ressalta o pesquisador da Universidade de São Petersburgo, Andrei Stiepanov (2005, p. 394), para Tchékhov a justiça e a igualdade entre os homens, pretendida pelos movimentos radicais, não era um ideal a ser obtido, mas dada a priori, pela própria igualdade de nossa condição física. O autor não acreditava em doutrinas ou classes sociais, mas no indivíduo:

Eu não acredito em nossa intelligentsia, que é hipócrita, falsa, histérica, maleducada e indolente, não acredito nem quando ela sofre e se lamenta, já que seus detratores provêm de suas próprias entranhas. Eu acredito em pessoas, vejo a salvação em indivíduos, espalhados aqui e ali por toda a Rússia, sejam membros da intelligentsia ou mujiques; é neles que reside a força, embora sejam poucos (TCHÉKHOV, 2007a, p. 91-92).

Em suas peças todas as classes estão presentes - intelectuais, camponeses, militares, artistas, comerciantes, aristocratas - mas são as personagens individualmente que adquirem destaque; obviamente a diferenciação social gera perspectivas distintas e por muitas vezes a impossibilidade de entendimento entre as personagens é causada justamente por suas formações, níveis de educação e cultura diferentes. O conflito entre personagens de classes sociais distintas embora existente, não impulsiona a ação dramática, no sentido tradicional do termo, pois não há um embate direto e linear através do diálogo; o choque entre elas está presente, mas não é "resolvido."

O momento histórico em que as personagens se situam, no qual transformações profundas estão em curso, molda os destinos de cada uma delas, mesmo que não se deem conta. Há, contudo, aquelas que têm plena consciência das mudanças em andamento, outras que fingem não tê-la e há ainda as que nada sabem com clareza, mas que sentem. Pretendemos a seguir, mostrar como as transformações históricas se descortinam na poética dramática tchekhoviana por meio dos problemas de comunicação.

\section{A ambivalência do progresso sob diferentes perspectivas}

Dentre as personagens que não compreendem as alterações sociais, políticas ou econômicas do presente, mas que as sentem, destaca-se o velho Firs de $O$ jardim das cerejeiras. Tchékhov apresenta em suas falas o choque entre os novos e velhos tempos, as contradições e incoerências resultantes das transformações inevitáveis em curso. Firs é o 
servo que quer ser servo, para quem a lealdade aos senhores está acima da liberdade; esta torna-se um fardo, não significa nada, a não ser confusão:

LOPÁKHIN: Antigamente é que era bom! Pelo menos se açoitava! FIRS (não ouviu bem): Digo o mesmo, a gente sabia quem era o camponês e quem era o senhor. Agora está tudo misturado, não se entende nada (TCHÉKHOV, 2006b, p. 92).

A fala simples e direta de Firs evidencia um mundo "de cabeça para baixo", em que a vida cotidiana de todos é transformada e não necessariamente para melhor. O criado fiel, pertencente a uma outra época, quando ainda se sabia preparar as cerejas, é quem encerra a última obra dramática de Tchékhov. Levados por seus destinos, animados pelos planos futuros ou carregados das lembranças do passado, todos abandonam a propriedade e Firs é literalmente esquecido. Instaura-se no presente, tempo de não-permanência e eterna transição, o vazio; restam a Firs apenas o silêncio e as portas trancadas. Entre as vozes que se foram e as machadadas que começam "lá fora", eternizam-se em nossos ouvidos, representadas pelos resmungos do velho Firs, as vozes dos mais frágeis.

As inevitáveis transformações históricas afetam, portanto, o destino de todas as personagens. Mas Tchékhov problematiza em toda sua obra a ambivalência destas mudanças.

Em sua análise de Fausto (1832) de Goethe (1749-1832), entendendo-a como a "tragédia do desenvolvimento" ${ }^{32}$, o filósofo norte-americano Marshall Berman (1940-) observa que o casal de velhos Filemo e Báucia (assim como a jovem Gretchen), vítimas das transformações violentas fomentadas por Fausto, personificam o que de melhor o velho mundo pode oferecer. Neste sentido, Filemo e Báucia, como o ancião de O jardim das cerejeiras, "são demasiado velhos, demasiado teimosos, talvez demasiado estúpidos para se adaptar e mudar; no entanto, são pessoas belíssimas, o sal da terra em que vivem" (BERMAN, 1999, p. 68). As mudanças inevitáveis e irreversíveis destroem a possibilidade de suas existências no presente, trancando-os perpetuamente no passado, circunscrito aos contornos cada vez mais vagos das memórias.

Assim, o tempo é claramente o grande protagonista de $O$ jardim das cerejeiras. No presente da cena representada, as personagens falam de como tudo mudou, de como a vida está passando, de como se sentem surpresas e cheias de incompreensão em face à passagem

\footnotetext{
${ }^{32}$ Em linhas gerais, Berman observa que a transformação de Fausto, na tragédia de Goethe, ocorre com a brutal e total transformação do mundo em que ele vive. A energia imensa empreendida por Fausto movimenta um processo de desenvolvimento em todos os âmbitos - econômico, intelectual, social e moral. O grande problema é o alto custo que este desenvolvimento representa para o ser humano (Cf. BERMAN, 1999, p. 37-84).
} 
inexorável do tempo; como se estivessem permanentemente em descompasso em relação a ele, como se o presente para sempre se lhes escapasse, parecem congeladas e atônitas em sua incompreensão.

A chegada de Raniévskaia à propriedade, depois de cinco anos vivendo em Paris, abre o primeiro ato da peça, que se encharca de lembranças. O comerciante Lopákhin, que aguarda ansiosamente sua chegada, recorda-se da infância difícil, maltratada pelo pai ignorante e bêbado, então servo da propriedade; todos se lembram da partida de Raniévskaia anos antes, depois de perder o pequeno filho Gricha e o marido; o primeiro ato se passa no "quarto das crianças", onde outrora dormiram não só ela e seu irmão Gáiev, mas muitas outras gerações da família aristocrata e onde todos os objetos exalam diversas dimensões de lembranças.

Se os diferentes tempos passados se pluralizam através das recordações, o tempo presente na propriedade, no entanto, está ameaçado; as muitas dívidas da família levaram o jardim das cerejeiras a leilão. Lopákhin, contudo, homem de negócios atento às mudanças do momento, apresenta já no primeiro ato um plano para salvar o jardim das cerejeiras:

LOPÁKHIN: [...] Se lotearmos o jardim das cerejeiras, e mais as terras à beira do rio, em terrenos para construção de casas de campo poderemos obter um rendimento garantido de mais de vinte e cinco mil rublos, livres! GÁIEV: Perdoe-me, mas isso é uma grande bobagem!

LIUBOV ANDRÉIEVNA: Não estou compreendendo bem, Ermolai Aleksêievitch.

LOPÁKHIN: [...] É claro, primeiro teria de por tudo em ordem, demolir as construções decrépitas, por exemplo, esta casa velha, que já não vale mesmo nada... e também o jardim de cerejeiras deveria ser derrubado...

LIUBOV ANDRÉIEVNA: Cortar as minhas cerejeiras? Ai, minha alma, perdoe-me, mas o senhor não sabe mesmo o que está dizendo. Em toda a região não há outro jardim de cerejeiras tão grandioso quanto o nosso.

LOPÁKHIN: A grandiosidade desse jardim resume-se ao fato de ele ser tão grande. Mas a produção de cereja é boa só a cada dois anos, quando muito, e mesmo então não se sabe o que fazer com ela. Ninguém a compra!

GÁIEV: Mas esse jardim é mencionado até nas enciclopédias! (TCHÉKHOV, 2006b, p. 77).

A possibilidade de compreensão entre Raniévskaia e Gáiev e o comerciante bem sucedido é inexistente desde os primeiros momentos da peça, pela incapacidade generalizada de se tentar apreender o ponto-de-vista um do outro. Para Lopákhin, o jardim, a casa e todas as construções "decrépitas" devem ser derrubadas para suprir as necessidades de uma nova época; para Gáiev e Raniévskaia, entretanto, este é um plano ilógico, sem sentido, "uma grande bobagem". 
Ao longo da peça, Tchékhov explora a diferença entre os pontos de vista dos aristocratas (que não entendem ou fingem não entender as mudanças do tempo presente) e do filho de ex-servos, dando aos leitores/espectadores a sensação de que "falam línguas diferentes". Apesar de ocuparem o mesmo tempo-espaço, permanecem distantes uns dos outros, atados cada qual a sua "verdade", impossibilitados de compreenderem e serem compreendidos.

Assim, o confronto existente entre as diferentes visões de mundo não impulsiona a ação dramática; a surdez que desconecta o diálogo no segundo ato revela pontos de vista paralelos, de realidades que não compartilham nenhum ponto de contato:

LOPÁKHIN: Está mais que na hora de tomar uma decisão. O tempo não espera. Querem o loteamento ou não querem? Preciso de uma resposta o mais breve possível: sim ou não? Apenas uma palavra!

LIUBOV ANDRÉIEVNA: Quem fuma charutos tão horríveis aqui? (Sentase.)

GAIEV: É mesmo bem conveniente o trem passar tão perto daqui. (Sentase.) Se quisermos ter um bom almoço, basta nos sentarmos numa cabine; o trem só para na cidade... uma bola da vez, depois uma numerada... De bom grado iria agora para casa e jogaria uma partidinha...

LIUBOV ANDRÉIEVNA: Tem tempo...

LOPÁKHIN: Apenas uma palavra! (Com voz suplicante.) Por favor, uma resposta!

GAIEV (boceja): O quê?

LIUBOV ANDRÉIEVNA (olhando dentro da bolsa): Ontem a minha bolsa ainda estava cheia de dinheiro e hoje de novo se esvaziou... [...] (TCHÉKHOV, 2006b, p. 88)

E mais adiante:

LOPÁKHIN: Perdoem-me, mas gente tão leviana como os senhores, tão estranha e pouco prática, eu nunca vi. Expliquei-lhes com bastante clareza, sem deixar dúvidas, que a sua propriedade será leiloada... e parece que isso não entrou na cabeça dos senhores...

LIUBOV ANDRÉIEVNA: Mas o que podemos fazer? Aconselhe-nos!

LOPÁKHIN: Dia após dia não faço outra coisa senão dar-lhes conselhos. Dia após dia falo e falo, cem vezes a mesma coisa [...]. (TCHÉKHOV, 2006b, p. 89-90).

O "diálogo de surdos", recurso típico da comédia e de que Tchékhov se utiliza nas cenas entre Andrei e o funcionário Ferapont de As três irmãs, ganha aqui um aspecto mais sutil, mas não menos absurdo. As réplicas de Raniévskaia e Gáiev, que não respondem diretamente às falas de Lopákhin, expõem os diferentes entendimentos de mundo que não admitem intersecção. Para os irmãos, a brancura das cerejeiras em flor remete-os à infância, à 
mãe, é uma imagem do passado idílico que carregam para a vida e não podem aceitar a possibilidade de sua extinção. Lopákhin, o novo capitalista, que tem o poder prático do dinheiro e para quem não há limites, tem do passado recordações bem diferentes - uma época em que "corria descalço pela neve em pleno inverno, semi-analfabeto".

No terceiro ato a propriedade é finalmente leiloada e adquirida por Lopákhin, a despeito das tentativas genuínas que fez para mantê-la nas mãos de Raniévskaia e Gáiev.
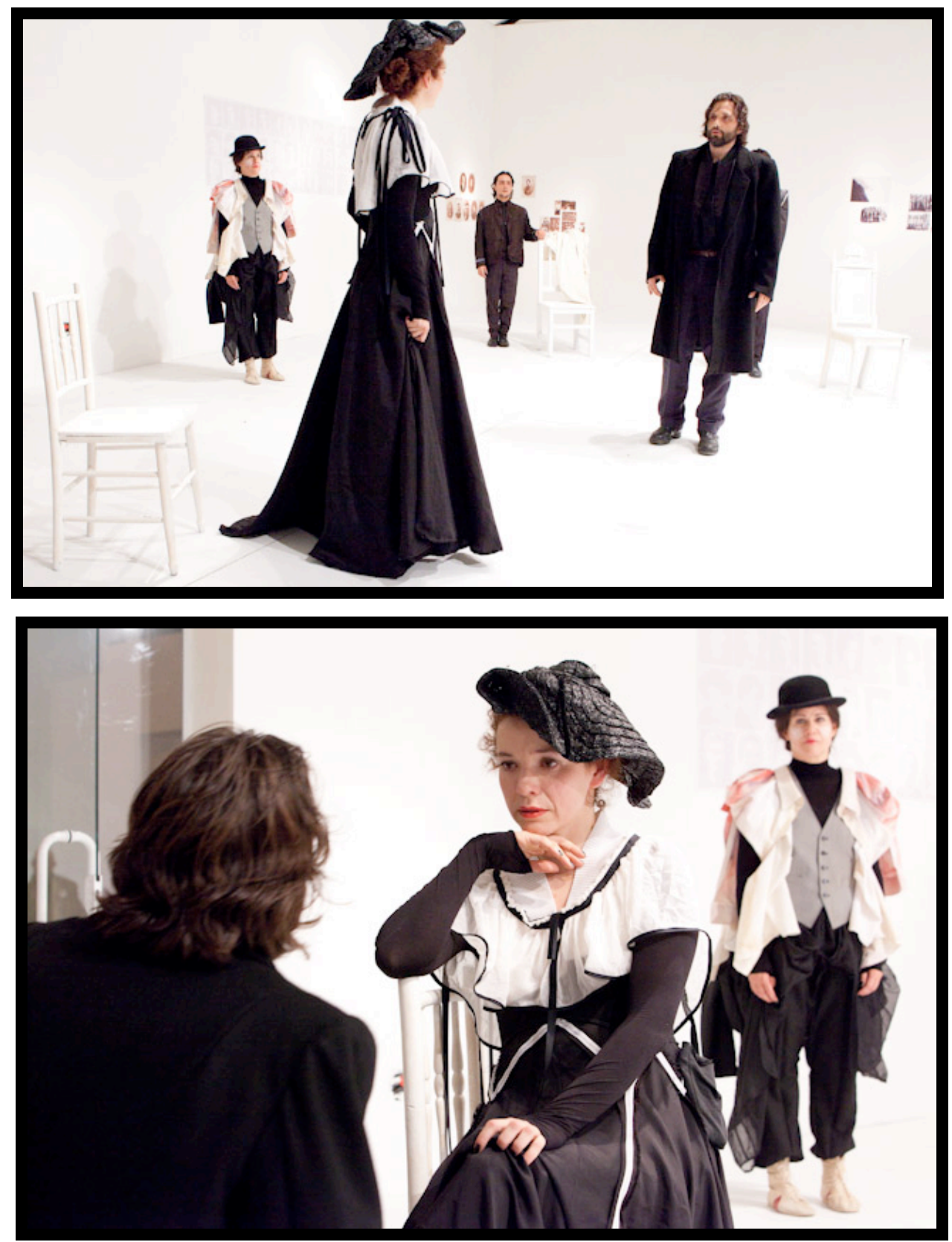

Cenas de Tchékhov ${ }^{4}$ - um estudo cênico. Direção: Adolf Shapiro. Raniévskaia (Lúcia Romano), Charlotta (Luah Guimarãez), Iacha (Fredy Allan) e Lopákhin (Sérgio Siviero) Fotos: Cacá Bernardes. 
O prático homem de negócios, contudo, não é "a fera que devora tudo o que atravessa seu caminho", como o define o "eterno estudante" Trofimov; como este mesmo nota mais tarde, Lopákhin tem as mãos sensíveis, como as de um artista, detalhe que abre outras dimensões da personagem, sutileza típica da poética tchekhoviana. Embora o comerciante enxergue no jardim das cerejeiras a possibilidade de lucro, valorizando seu sentido utilitário, ao comprá-la, declara-se dono "da propriedade mais bonita do mundo", em que o pai e o avô não podiam entrar "nem pela porta da cozinha". A compra da propriedade alarga de vez o abismo que separa Lopákhin das demais personagens, mas assim como a perda do jardim não é o único motivo da infelicidade de Gáiev e Raniévskaia, sua aquisição também não traz a Lopákhin felicidade: "Que tudo passe o mais rápido possível; que essa nossa pobre e infeliz vida mude de alguma forma, e o mais rápido possível..." (TCHÉKHOV, 2006b, p. 109).

A inevitabilidade das transformações de uma nova época, que apesar dos proclamados benefícios traz em si a destruição do que também é belo, afeta, consequentemente, a todos. O conflito entre as duas visões de mundo não apresenta "solução"; ao invés de colidirem, elas correm paralelas, compartilhando tempo e espaço em linhas que jamais se encontram, que nunca atingirão uma síntese.

A encenação de $O$ jardim das cerejeiras pelo Teatro de Arte de Moscou em 1904, foi um marco na história da companhia e influenciou muitas leituras posteriores da obra, que a assimilaram como uma peça sobre as mudanças nas estruturas sócio-econômicas e culturais da Rússia da época.

Stanislávski e Nemiróvitch-Dântchenko valorizaram na montagem os aristocratas Raniévskaia e Gáiev, interpretados pelos melhores atores do TAM, Olga KnípperTchékhova $^{33}$ (1868-1959) e o próprio Konstantin Stanislávski, embora Tchékhov o desejasse para o papel de Lopákhin $^{34}$. O empobrecimento da nobreza, a impotência ante às transformações históricas e a perda da casa tomaram a linha central da encenação, que assumia um tom lírico de "adeus ao passado".

O diretor Adolf Shapiro nos ensaios em São Paulo observou que a questão da perda da casa, presente em toda poética dramática tchekhoviana, na concepção de Stanislávski adquiria contornos trágicos, que o diretor imprimiu fortemente em sua encenação, por sua própria história pessoal (Stanislávski provinha de uma tradicional família de industriais abastados, ele mesmo dividindo-se entre as artes cênicas e os negócios). Para Tchékhov, que desde cedo

\footnotetext{
${ }^{33}$ Atriz do Teatro de Arte de Moscou, casou-se com Tchékhov em 1901.

${ }^{34}$ Ver carta de Tchékhov à esposa de Stanislávski, Maria Petrovna Alekséieva, de 15 de setembro de 1903, publicada em Teatro II (TCHÉKHOV, 2006b, p. 123).
} 
acostumou-se a mudanças constantes de casa e cidade (o autor deixou sua cidade natal aos dezessete anos e devido à tuberculose, foi obrigado a trocar sua querida Moscou por cidades ao sul da Rússia, de clima mais ameno), a encenação do TAM era "chorosa"; Tchékhov ainda indignava-se pela companhia anunciar em seus cartazes a peça como "drama", já que acreditava ter escrito uma "comédia". Para Shapiro, Stanislávski optou por mostrar o drama escondido na peça, tão bem amalgamado por Tchékhov com momentos cômicos e por vezes mesmo farsescos.

Por certo $O$ jardim das cerejeiras, escrita lentamente como uma despedida, trata das mudanças que eclodiam na sociedade russa da época e que nos próximos anos culminariam nas revoluções. Todavia, está longe de ser uma obra apenas sobre as mudanças históricas; o autor concentra-se nas diferentes personagens, de classes sociais, idades e culturas distintas que têm seus destinos alterados também por estas mudanças. A passagem inflexível do tempo, a incapacidade da evolução sem a destruição da natureza, a inabilidade de se fazer dos sonhos realidade, são abordados por Tchékhov nas relações entre as personagens, habitantes de universos singulares, em um presente de constantes incertezas.

Uma imagem idílica construída a cada dia: Moscou

Em As três irmãs, o presente também parece escapar às protagonistas, que habitam mais o plano do passado, através das memórias, e o plano do futuro, através de sonhos e desejos imaginados na distante Moscou. O conflito entre a vida cotidiana e a vida com que se sonha toma dimensões profundas, ainda mais acentuadas pela presença de personagens que sabem aproveitar as oportunidades do presente, que ajudam a instaurar um cotidiano cada vez mais vulgar.

Exiladas na província, as protagonistas de As três irmãs veem pouco a pouco seus sonhos, ilusões e valores esmagados pela vida monótona, em que as pessoas "só comem, bebem, dormem" e ocupam suas vidas com "mexericos venenosos, vodca e cartas". $\mathrm{Na}$ província, a beleza das florestas e a força dos rios são arruinadas pela ignorância dos habitantes.

A realidade provinciana era familiar a Tchékhov e o retrato que traça de Taganrog, quando aos vinte e sete anos retorna à cidade natal em breve visita, é muito similar às descrições de Andrei da pequena cidade de As três irmãs: 
Sessenta mil habitantes, cuja única preocupação é comer, beber, reproduzirse, sem nenhum outro interesse... Por onde quer que se vá só há bolinhos, ovos, santorrinos, criancinhas de peito, mas nada de livros, de jornais... O lugar onde fica a cidade é bonito, sob todos os aspectos, o clima é esplêndido, há uma enormidade de frutas, mas o povo é inerte, que é o diabo... São todos dotados musicalmente, têm uma fantasia e um humor excelentes, são sensíveis, nervosos, mas isso tudo acaba dando em nada... Não há patriotas, nem negociantes, nem poetas, nem mesmo padeiros decentes (TCHÉKHOV, 2002a, p. 43-44).

Olga, Macha, Irina e o irmão Andrei, após a morte do pai, militar transferido para a província, alimentam o sonho de voltar à terra natal, Moscou. A capital concentra as aspirações e sonhos da família Prózorov: Andrei sonha em ser professor da universidade, Irina em encontrar o amor, Olga em livrar-se da ocupação de professora; Macha, casada com Kulíguin, professor local, é a única antecipadamente condenada a permanecer na província.

Mas Tchékhov parece sugerir ao leitor/espectador logo no início da peça o que as personagens só terão consciência ao fim de suas trajetórias: ao justapor diferentes diálogos, o desejo de ir a Moscou é sutilmente ironizado. Nos momentos iniciais da peça, quando Olga e Irina o expõem pela primeira vez, ouvimos exclamações e risadas de Tusenbach e Tchebutíkin, que conversam com Solióni ao fundo sobre outro assunto:

OLGA: [...] Meu Deus! Quando acordei hoje de manhã e vi toda esta luz, a primavera, meu coração se encheu de alegria e desejei ardentemente estar em minha cidade natal.

TCHEBUTÍKIN: Que nada!

TUSENBACH: Claro, que bobagem! (TCHÉKHOV, 2006b, p. 7-8).

E logo em seguida:

IRINA: Que mudemos para Moscou! Vendamos a casa, deixemos tudo e partamos para Moscou.

OLGA: O quanto antes! (Tchebutíkin e Tusenbach riem) (TCHÉKHOV, 2006b, p. 8).

Da mesma forma, o desejo de Olga em se casar, mesmo sem amor, também é ironizado:

OLGA: [...] se me casasse e passasse o dia em casa seria melhor. (Pausa) Eu amaria o meu marido...

TUSENBACH (a Solióni): O senhor diz tanta bobagem que nem vale a pena escutá-lo (Entra na sala) (TCHÉKHOV, 2006b, p. 8). 
O procedimento adotado por Tchékhov ao colocar "em diálogo" dois diálogos paralelos, referentes a contextos distintos, é carregado de sutileza e singularidade. Da mesma maneira, no segundo ato a impossibilidade de ir a Moscou é pressagiada no jogo de paciência que não dá certo e no terceiro pela quebra do relógio que pertencia à falecida mãe. Moscou também está presente nas falas senis do funcionário surdo Ferapont, que nunca esteve na cidade e atribui a ela os eventos mais absurdos e improváveis: o comerciante que se empanturra de panquecas e morre, o frio de mais de duzentos graus negativos, o incêndio e a corda esticada por toda cidade...

Assim, Moscou centraliza as aspirações das irmãs Prózorov na tentativa de voltarem ao tempo-espaço idealizado de suas infâncias, configurando-se como uma necessidade essencial, uma imagem construída para possibilitar a vida sob as circunstâncias pesarosas do presente. Como ressalta Donald Rayfield, "Moscou é a medida de tudo: Olga recorda-se de que, enquanto as bétulas da província ainda estão em botão, as de Moscou já estão florescendo" (RAYFIELD, 1975, p. 217). "Moscou, Moscou" torna-se um refrão, repetido por Irina e encerrando emblematicamente o segundo e terceiro atos.

A chegada dos militares em uma atmosfera festiva e ensolarada no primeiro ato conecta as irmãs ao passado, pelas lembranças que compartilham com o coronel Verchínin, também de Moscou, ao mesmo tempo em que o futuro é exaltado pelos planos de regresso à capital; no intervalo de dois anos entre o primeiro e segundo atos, contudo, a província pouco a pouco soterra os sonhos dos Prózorov, alargando a distância entre a vida que se leva e a vida que se sonha em Moscou.

Andrei troca os estudos por um posto de funcionário do conselho rural e casa-se com Natacha, moça simples da burguesia local. A diferença entre esta e as irmãs Prózorov estabelece-se prontamente no primeiro ato, em uma cena ditada pela sutileza do humor tchekhoviano:

NATACHA: A reunião hoje está muito concorrida, fico acanhada... OLGA: Ora, todo mundo aqui é de casa. (A meia-voz, assustada) Meu Deus, está usando cinto verde? Querida, isso é simplesmente impossível! NATACHA: Por acaso significa algo ruim? OLGA: Não, não, apenas lhe vai terrivelmente mal. Como se... NATACHA (chorosa): É mesmo? Mas quase nem é verde, de tão pálido (TCHÉKHOV, 2006b, p. 21).

Os desentendimentos entre Natacha e as irmãs seguem em um ritmo crescente, evidenciando os valores, crenças e formações que não compartilham. As irmãs admitem que 
são diferentes, conhecem muitas coisas "inúteis" para a província: "Saber três línguas nesta cidade é um luxo desnecessário. É até mais que um luxo: é simplesmente uma coisa inútil, como um sexto dedo. Sabemos muita coisa desnecessária" (TCHÉKHOV, 2006b, p. 17). Harvey Pitcher (1985, p. 130) observa que a formação dos Prózorov em verdade, os preparou para um mundo muito melhor do que aquele em que de fato vivem; diante da vulgaridade que encontram na província permanecem espantados, sem saber como agir.

Natacha, assim como Lopákhin, é representante de uma nova organização de mundo, tem uma inteligência prática, pautada pela capacidade de resolver problemas. Na província e nos novos tempos que se apresentam estas qualidades passam por cima dos valores e nobreza das irmãs. Gradualmente, Natacha domina os espaços da casa, encurralando os Prózorov em quartos cada vez menores, até expulsar a todos, pela própria ausência de oposição que encontra. Diante da ignorância e histeria de Natacha, todos recuam; e ao se recusarem à ação, tornam-se cada vez mais vulneráveis.

Se logo na chegada de Natacha já ficam claras as diferenças entre ela e as irmãs, no terceiro ato tais diferenças culminam em um impasse entre as personagens, que têm plena consciência da impossibilidade de entendimento, como se também falassem línguas estranhas:

NATACHA: [...] (A Anfissa, fria.) Quando estou aqui não se atreva a ficar sentada! Levante-se, saia daqui! (Anfissa sai. Pausa) Não posso entender por que você mantém essa velha.

OLGA (perplexa): Desculpe, tampouco eu entendo...

$[\ldots]$

OLGA: [...] Há pouco você foi muito grosseira com a babá. Perdoe-me, mas eu não posso suportar isso... fiquei com a vista turva...

NATACHA (agitada): Perdoe-me Olia querida, não quis afligi-la. (Macha levanta-se, pega o travesseiro e retira-se furiosa).

OLGA: Compreenda, querida, que talvez nós tenhamos sido educadas de modo estranho, mas eu não posso suportar isso. Esse tipo de comportamento me deprime... eu fico doente...

NATACHA: Bem, me perdoe. (Beija-a).

OLGA: A mínima grosseria, uma palavra menos delicada, me altera...

NATACHA: Pode ser que às vezes eu fale demais. Mas você tem que reconhecer, querida: a babá bem que poderia ter ficado na aldeia.

OLGA: Ela está conosco há trinta anos.

NATACHA: Mas já não pode trabalhar. Ou sou eu quem não entende ou é você que não quer me entender. Ela não serve para o trabalho; só dorme ou fica sentada.

OLGA: Então que fique sentada.

NATACHA (admirada): Ficar sentada? Mas é uma criada! (Desata a chorar) Não a compreendo, Olga. Tenho uma babá, uma ama-de-leite, uma criada, uma cozinheira... Então para que precisamos dessa velha? Para quê?

OLGA: Envelheci dez anos esta noite (TCHÉKHOV, 2006b, p. 42). 
O impasse entre Olga e Natacha apresentado na cena acima é consequência da nova natureza do conflito da poética dramática tchekhoviana, em que estes se desmancham sem se resolverem. Ao invés do embate direto, há a incompatibilidade: as irmãs representam a capacidade do sonho e a sensibilidade em seu grau mais refinado, têm o olhar nas estrelas; Natacha tem a habilidade de cuidar dos pequenos problemas do dia-a-dia, das coisas miúdas, tem o olhar fixo a sua frente. Delineiam-se, portanto, diferentes visões de mundo obrigadas pelo destino a compartilharem o mesmo espaço. Ante a falta de oposição das irmãs, é inevitável que Natacha, seguindo sua lógica pequeno-burguesa, individualista, passe a ocupar os espaços mais ensolarados e por fim, toda a casa. A vida prossegue seu curso, não há culpados, mas múltiplas verdades.

Obviamente a crueldade de Natacha, claramente presente na cena com a velha criada Anfissa, afeta a todos e mostra o sentido utilitário que ela também transfere às relações pessoais. Alheia à nobreza, assim como às dúvidas, incertezas e sofrimentos das irmãs e do marido, Natacha tem olhos apenas para si e para os filhos; e até o amor por eles torna-se expressão de mesquinharia e egoísmo.

A tridimensionalidade característica das personagens tchekhovianas, no entanto, não deixa que Natacha se transforme em uma figura caricata, vil. Além disso, Tchékhov afirmara em carta que a obra era protagonizada por quatro mulheres inteligentes, o que inclui Natacha $^{35}$. Sua inteligência circunscreve-se às oportunidades que o presente lhe oferece e que ela sabe aproveitar.

Ao fim da peça, a mãe de Bóbik e Sófotchka distancia-se completamente dos Prózorov, isolada pelos muros que ela própria levantou com seu pragmatismo, as preocupações neuróticas com as crianças, a surdez e incapacidade de compreender o que se passava ao seu lado. A rubrica "desata a chorar", se de um lado atesta a histeria de Natacha, por outro refere-se ao cansaço e solidão de alguém que sabe que é diferente.

Dividido entre a esposa e as irmãs, Andrei percebe a impossibilidade de comunicação entre os dois mundos apenas ao fim da peça, quando a imagem que ele tem de Natacha se altera radicalmente em relação ao primeiro ato: "[...] às vezes acho que ela é assombrosamente vulgar, e então fico desconcertado, não compreendo para que e por que a amo, ou pelo menos a amei algum dia..." (TCHÉKHOV, 2006b, p. 57).

Assim, a vulgaridade da vida na província e a partida definitiva dos militares desmancham os sonhos e desejos dos Prózorov. Mas a resposta das irmãs a tal destino não

\footnotetext{
${ }^{35}$ Cf. TAKEDA, 2003, p. 152.
} 
deixa de ser surpreendente. Passam a buscar um sentido para suas vidas presentes, reais, ainda que tal procura tenha nascido de farrapos de sonhos desfeitos.

O teatro dentro do teatro: velhas e novas formas

Se em O jardim das cerejeiras e As três irmãs há desentendimentos entre personagens de diferentes classes sociais, que por suas formações distintas não compartilham os mesmos valores, ideias ou visões de mundo, em A gaivota, Tchékhov apresenta a impossibilidade de entendimento entre seres muito próximos, mas representantes de gerações distintas - mãe e filho. O próprio teatro é o objeto frequente do desentendimento entre ambos.

De um lado temos o teatro "estabelecido", personificado pela atriz de província Arkádina e o profissionalismo diligente do famoso escritor Trigórin; de outro, temos o jovem autor Tréplev, contrário à mediocridade de "morais pequeninas e fáceis" do velho teatro, em busca por "formas novas":

TRÉPLEV: [...] Quando a cortina sobe e, à luz da noite, entre as três paredes, esses talentos formidáveis, os sacerdotes da arte sagrada, representam como as pessoas comem, bebem, amam, andam, vestem seus casacos; quando, das cenas e das frases mais banais, tentam desencavar uma moral - pequenina, fácil de entender, útil para fins domésticos; quando, em mil variantes, me apresentam sempre a mesma coisa, a mesma coisa e a mesma coisa, então eu fujo correndo, como Maupassant fugia da torre Eiffel, que lhe oprimia o cérebro com sua vulgaridade.

SÓRIN: É impossível viver sem o teatro.

TRÉPLEV: Precisamos de formas novas. Formas novas são indispensáveis e, se não existirem, então é melhor que não haja nada [...] (TCHÉKHOV, 2004a, p. 13-14).

O embate entre velhas e novas formas artísticas personifica-se na relação entre mãe e filho, expresso nas crenças artísticas opostas. Arkádina é a grande atriz, que tem "a necessidade de criar um mundo especular diante da precariedade da vida" (FERNANDES; RAMOS, 2007, p. 228), agindo na vida como age no velho palco - se o filho ou o irmão precisam de dinheiro, ela chora, afirmando não ter nada; as primeiras réplicas que troca com Tréplev não são de um diálogo espontâneo entre mãe e filho, mas emprestadas de Gertrudes e 
Hamlet; por fim, quando no terceiro ato tem ciúmes de Trigórin ajoelha-se aos seus pés, como provavelmente o faria em $A$ dama das camélias ${ }^{36}$ ou em outra personagem-título tuberculosa.

O choque entre Tréplev e Arkádina já se evidencia no começo de $A$ gaivota com o fracasso da peça do jovem autor, cujas novas formas apregoadas são ironizadas pela mãe:
ARKÁDINA: Sinto cheiro de enxofre. Será mesmo necessário?
TRÉPLEV: É, sim.
ARKÁDINA (ri): Ah, é um efeito especial.
TRÉPLEV: Mãe!
NINA: Ele se entendia, sem ninguém...
POLINA (para Dorn): O senhor tirou o chapéu. Cubra-se, ou vai se resfriar. ARKÁDINA: O médico tirou o chapéu porque está diante do diabo, o pai da matéria eterna.
TRÉPLEV (com raiva, erguendo a voz): A peça acabou! Chega! Baixem a cortina! (TCHÉKHOV, 2004a, p. 22-23).

O entendimento entre Arkádina e Tréplev torna-se impossível não só pela oposição e inflexibilidade de seus pontos de vista, mas assim como Raniévskaia e Gáiev não podem compreender os planos de Lopákhin, ou Natacha os valores nobres das irmãs, Arkádina não consegue entender a necessidade de novas formas de Tréplev.

As reações exageradas, tanto do jovem autor como de Arkádina, também demonstram a fragilidade da comunicação entre ambos. A atriz transfere dos palcos nos quais representa para a plateia do teatro do filho suas ações e reações exageradas, enxergando a "nova era na arte" como má índole e afronta pessoal. Tréplev, por sua vez, interrompe abruptadamente a representação, pois pressente que a mãe está contra ele, porque "nesse palco minúsculo, Zariêtchnaia vai brilhar, e não ela" (TCHÉKHOV, 2004a, p. 12).

Tréplev já no início da peça nos dá em detalhes paradoxais o retrato da mãe, "um caso psicológico muito curioso", que pode cuidar dos doentes "como um anjo", mas não pode "ouvir alguém elogiar Duse em sua frente". Arkádina ama o teatro, é uma diva, suscetível a humores extremos, vaidosa e avarenta. Seu egoísmo traduz-se na surdez que a impede de compreender a angústia do filho. Quando Dorn no último ato pergunta a ela se está contente por Tréplev ter se tornado um escritor publicado, sua resposta é categórica: "Imaginem só: eu ainda não li. Nunca tenho tempo" (TCHÉKHOV, 2004a, p. 89). Mais uma vez entra em ação

\footnotetext{
${ }^{36}$ Romance de Alexandre Dumas Filho (1824-1895), de 1848, adaptado para o teatro pelo próprio autor. A grande atriz Sarah Bernhardt (1844-1923) ficou famosa no papel título, que Tchékhov havia visto na temporada russa em 1881. As duas críticas que publicou revelam o desgosto do dramaturgo pela interpretação exagerada da diva. Tchékhov preferia a simplicidade e sinceridade da atriz italiana Eleonora Duse (1858-1924), que o impressionara no papel de Cleópatra.
} 
o humor peculiar de Tchékhov, já que a fala é proferida em meio ao tedioso jogo de víspora, em uma longa noite de outono.
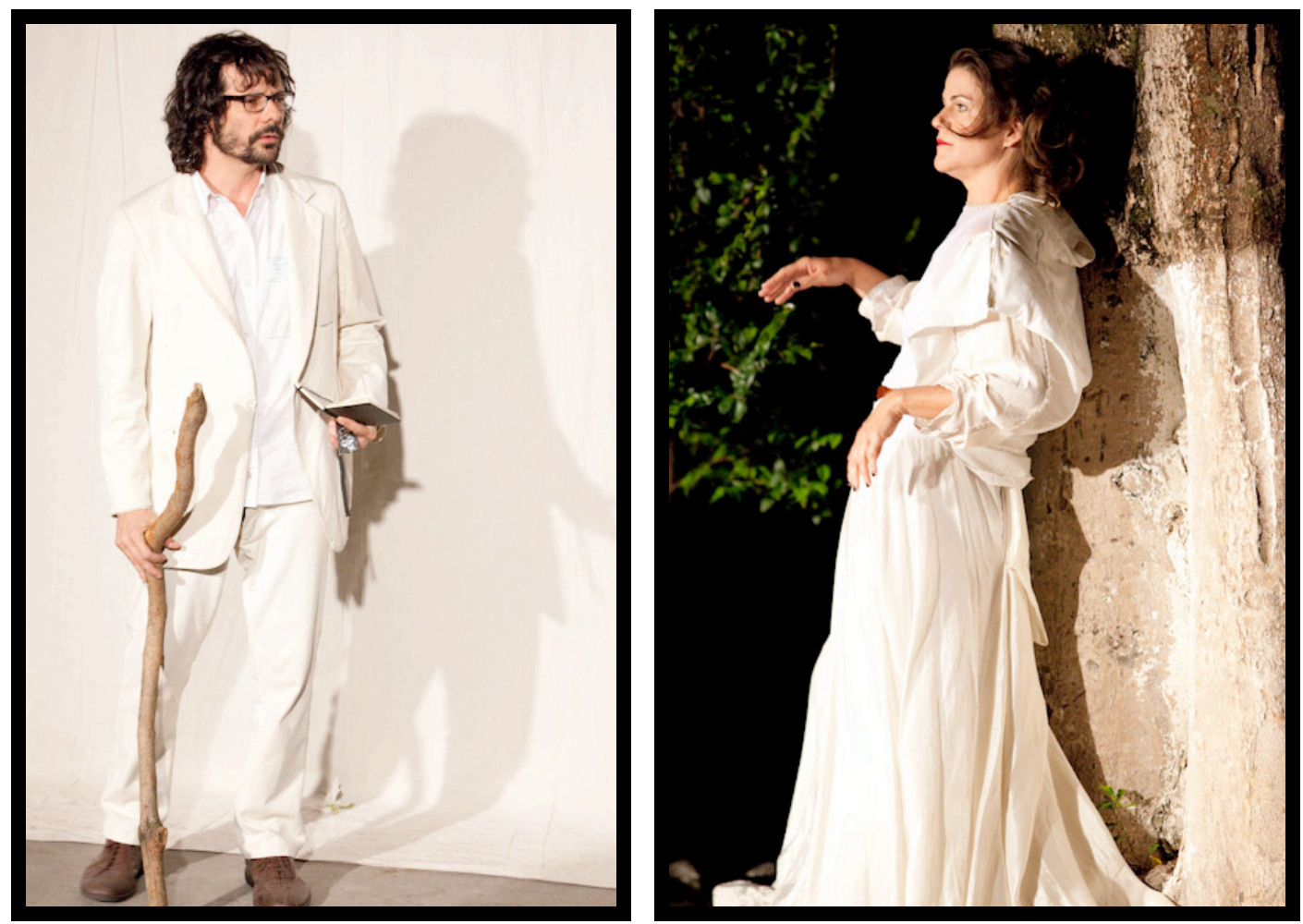

O primeiro ato de $A$ gaivota no estudo dirigido por Adolf Shapiro: Tréplev (Silvio Restiffe) e Arkádina (Luah Guimarãez). Fotos: Cacá Bernardes.

Tréplev, com o passar do tempo estabelece-se no meio profissional literário, aproximando-se do círculo de Arkádina e Trigórin; sente-se, no entanto, sufocado pela regularidade mediana, vulgar:

TRÉPLEV (põe-se a escrever; passa os olhos pelo que já escreveu): Eu, que falava tanto em formas novas, agora sinto que, pouco a pouco, vou também caindo na rotina. (Lê) "Um cartaz na cerca apregoava... Um rosto pálido, emoldurado por cabelos escuros..." Apregoava, emoldurado... Isto é medíocre [...] (TCHÉKHOV, 2004a, p. 90).

Tréplev conclui que a questão não está na forma:

TRÉPLEV: Cada vez mais me convenço de que a questão não consiste em formas novas e formas velhas, mas sim em que a pessoa escreva sem pensar em formas, sejam quais forem, que ela escreva porque isso flui livremente de sua alma (TCHÉKHOV, 2004a, p. 91). 
Assim como a realidade cotidiana da província afunda os sonhos das três irmãs, o velho teatro sobrepõe-se às aspirações do jovem autor. Tréplev queima todos os seus manuscritos e suicida-se. Como conclui Donald Rayfield (1975, p. 207), todo talento humano é engolido pelo teatro da província; apenas a carcaça do novo teatro, construído à beira do lago, sobrevive, envelhecendo prematuramente, sob as gaivotas que voam indiferentes.

Olhamos as estrelas, mas por quê voamos tão baixo?

As mudanças do tempo histórico na poética dramática tchekhoviana, refletidas no presente incerto e no passado que adquire contornos idílicos, fazem com que muitas das personagens se lancem ao futuro, na crença de que mesmo distante, este será inevitavelmente melhor.

Trofimov, o estudante rebelde de O jardim das cerejeiras, é uma das personagens que acredita no futuro, que incita Ánia, jovem filha de Raniévskaia e por quem é apaixonado, a deixar o passado em que a propriedade está mergulhada e a olhar para frente. Para Trofimov, no entanto, não é a destruição do mundo antigo, mas a renúncia ao velho modo de vida injusto, que permitia a poucos viverem sob às custas do trabalho de muitos, o que realmente está em jogo.

O conflito, sempre presente na poética dramática tchekhoviana, entre o plano ideal e o do real, revela-se no caso de Trofimov no próprio apelido dado a ele - o "eterno estudante". De um lado estão os discursos idealistas do jovem, que exaltam as mudanças sociais, a liberdade e o trabalho:

TROFIMOV: [...] Vivemos num atraso de pelo menos duzentos anos. Pouco mais que nada aconteceu em nossa terra, não temos nenhuma atitude definida em relação ao passado... apenas filosofamos, queixamo-nos das nossas tristezas e bebemos vodca... No entanto é tudo tão claro!... Se quisermos de fato viver verdadeiramente o presente, então primeiro temos de expiar o passado, temos de liquidá-lo; e só podemos expiá-lo com sofrimentos e um trabalho infatigável e intenso. Ánia, guarde bem isso na cabeça!

ÁNIA: A casa onde moramos não nos pertence há muito. Deixarei essa casa, juro!

TROFIMOV: Se estiver com as chaves da casa atire-as neste poço e vá embora daqui. Seja livre como o vento... (TCHÉKHOV, 2006b, p. 96-97). 
De outro, está a própria vida incerta de Trofimov, que no plano do cotidiano concreto nada faz; Raniévskaia é quem claramente nota a imaturidade do estudante, a quem chama de "ginasiano":

LIUBOV ANDRÉIEVNA: [...] De bom grado casaria Ánia com o senhor, juro, mas precisa estudar e concluir o curso... Acontece que o senhor nada faz; deixa que o destino o arraste de um lado para outro, e no entanto sabe que isso não está certo, não é? $\mathrm{E}$ além disso, teria de fazer algo com essa barba... para que crescesse um pouco.... (Ri) É tão engraçado o seu rosto assim sem barba... (TCHÉKHOV, 2006b, p. 103).

Para Vladímir Nabókov, Tchékhov apresenta em sua obra personagens que combinam na mesma proporção uma ampla capacidade de sonhar com o futuro e um grande despreparo para com a vida prática; agregam "a mais profunda decência humana de que o homem é capaz com uma inabilidade quase ridícula em pôr seus ideais e princípios em prática" (NABOKOV, 1981, p. 253).

É o caso também de Verchínin, cujos discursos cativam as irmãs Prózorov e iluminam o futuro ao tecerem a crença de que este será mais brilhante que o presente. O choque, porém, reside entre as palavras de Verchínin e a realidade, como observa Harvey Pitcher:

As palavras agradáveis de Verchínin e suas aspirações nobres nunca foram igualadas por nenhuma realização comparável em sua vida pessoal; a combinação entre sentimentos nobres e a ineficácia prática parece epitomar o liberal russo do fim do século XIX (PITCHER, 1985, p. 126).

Ao mesmo tempo em que sonha com um mundo mais justo, verdadeiro e belo, Verchínin é incapaz de administrar os problemas de sua vida pessoal. Durante toda a peça sabemos das dificuldades com a esposa e as filhas, que Tusenbach antecipa antes mesmo da entrada de Verchínin no primeiro ato.

O militar, contudo, mostra consciência da distância entre "falar" e "fazer" e ao invés de responder, se questiona:

VERCHÍNIN: [...] Seja civil ou militar, nas reuniões sociais só se ouve dizer: está tendo problemas com a mulher, está tendo problemas com a casa, está tendo problemas com o cavalo... Nós, russos, gostamos demais dos pensamentos elevados, mas, me diga, por que na vida real voamos tão baixo? Por quê? (TCHÉKHOV, 2006b, p. 27). 
A impossibilidade em ser feliz e também a de fazer outros felizes reflete-se no paradoxo entre o ideal e a vida cotidiana que metaforiza a contradição de Verchínin e de tantas outras personagens do teatro tchekhoviano.

O trabalho surge então, para muitas personagens, como a possibilidade concreta de alteração da vida presente, cotidiana. Mas desta possibilidade nascem novas contradições.

No início de As três irmãs a certeza da necessidade do trabalho como fonte de felicidade, prazer e sentido da vida transborda em Irina; mas ao longo da obra com as decepções nos diferentes empregos que assume, esta confiança é quase destruída pela realidade massacrante da província. $\mathrm{O}$ barão Tusenbach, ao contrário, torna-se cada vez mais crente no trabalho, ainda que ironicamente, nunca tenha trabalhado. Nota-se mais uma vez o conflito entre o ideal e o real, de homens que "passavam noites em claro planejando mundos que não podiam construir" (NABOKOV, 1981, p. 254). O pragmático Kulíguin, professor da província, facilmente identifica tal contradição: "Tudo isso é bonito, mas não muito sério. Apenas ideias, sem muita seriedade" (TCHÉKHOV, 2006b, p. 54).

Para Tusenbach, a única possibilidade de resposta para o sentido da vida encontra-se no trabalho; ao contrário de Verchínin e Trofimov, para o barão as questões do presente são as mesmas que permanecerão no futuro:

TUSENBACH: [...] Não apenas dentro de duzentos ou trezentos anos, mas daqui a um milhão de anos, a vida continuará sendo o que era. Ela não muda, permanece constante, sujeita a leis próprias, independentes de nós, ou pelo menos que não conheceremos jamais. Os pássaros migrantes, as cegonhas, por exemplo, voam e voam, e, sejam elevados ou mesquinhos os pensamentos que se agitam em sua cabeça, seguirão voando sem se importar com os filósofos que possam existir entre eles; e que filosofem quanto quiserem, desde que voem!

MACHA: Mas qual é o sentido disso?

TUSENBACH: Sentido... Veja, está nevando. Qual sentido tem isso? (Pausa) (TCHÉKHOV, 2006b, p. 30-31).

Tusenbach, entretanto, vem de uma classe completamente alheia ao trabalho:

TUSENBACH: Eu compreendo - e como! - que as pessoas desejem trabalhar. Em toda a minha vida nunca trabalhei. Nasci na fria e indolente São Petersburgo, numa família que nunca soube o que era trabalhar e nunca conheceu privações. Recordo-me, quando voltei para casa depois da academia militar, era o lacaio quem me tirava as botas; naquela época eu era cheio de caprichos, porém a minha mãe me olhava maravilhada e ficava admirada se os outros não me vissem do mesmo modo. Preservaram-me do trabalho. Porém, não conseguiram me afastar dele por completo. É chegada a hora, já se aproxima, uma imensa e saudável tempestade está por vir, já está 
a caminho, daqui a pouco chegará aqui e afugentará da nossa sociedade a indolência, a indiferença, o preconceito contra o trabalho, o tédio putrefato. Trabalharei. Daqui a vinte e cinco ou trinta anos todos os homens trabalharão. Todos! (TCHÉKHOV, 2006b, p. 10).

Os planos de Tusenbach de casar-se com Irina e trabalhar em uma fábrica de tijolos, contudo, são extintos prematuramente no quarto ato por sua morte em duelo com Solióni.

O sonho "planejado" por estes idealistas, tão contrastante com a vida cotidiana na província, faz também com que se encontrem isolados. O entendimento entre Olga, Macha e Irina e os militares, que compartilham memórias e desejos, transforma no primeiro ato a casa dos Prózorov em uma ilha de resistência à ignorância da província. Pouco a pouco, com o controle assumido por Natacha e a passagem do próprio tempo, a resistência é dissipada.

$\mathrm{O}$ isolamento destes idealistas na província é claramente manifesto por Ástrov em $O$ tio Vânia. O médico conhece bem o ambiente de pobreza, em que se contam copeques, as estradas em péssimas condições, a ignorância dos camponeses e a soberba dos intelectuais. Ao viver sob tais circunstâncias, sente-se totalmente incompreendido:

ÁSTROV: [...] Os camponeses não tem graça, são atrasados e vivem na sujeira e com os intelectuais é difícil conviver. Eles só me cansam. Os nossos conhecidos mais próximos são, sem exceção, limitados no pensar e no sentir, não enxergam um palmo adiante do nariz - ou seja: são estúpidos. Os mais inteligentes ou de maior valor são histéricos, consumidos pela análise, pela reflexão... Esses vivem se lamentando, se odiando, caluniam uns aos outros de modo doentio, nos abordam de esguelha e nos olham de viés e constatam: "Oh, esse é um psicopata", ou "esse é um tagarela"! E quando não sabem como nos tachar, então dizem: "Sujeito estranho, aquele, muito estranho!" Eu gosto dos bosques - isso é estranho; não como carne isso também é estranho. A relação com a natureza e com as pessoas não é mais uma relação espontânea, pura e livre... Não é não (TCHÉKHOV, 1998b, p. 91-92).

O conflito entre ideal e real enfrentado por estas personagens e que permanece sem solução, confere a cada uma delas amplitude, fazendo com que estejam longe de serem heróis de uma verdade, doutrinadores de novas ideias. Todas elas vislumbram uma vida melhor, ainda que não possam construí-las.

A capacidade destes sonhadores em vislumbrar o futuro parece afastá-los do contato real com os que estão próximos: dialogam com o distante, mas não com quem está ao lado. Tchékhov, em carta a Suvórin, assim diagnostica o problema: "O mal, portanto, não reside no fato de odiarmos nossos inimigos, que são poucos, mas no fato de não amarmos suficientemente os que nos são próximos, que são muitos, de se perder a conta" 
(TCHÉKHOV, 2002a, p. 87). Sem condenar suas personagens, Tchékhov deixa que as reticências sigam as interrogações levantadas por elas. Mas parece sugerir que a simples existência daqueles que fazem perguntas, ainda que não obtenham respostas, indica a chegada de dias melhores. 


\section{INOVAÇÕES DO SISTEMA DRAMÁTICO TCHEKHOVIANO}

Ser significa comunicar-se pelo diálogo. M. M. Bakhtin ${ }^{37}$

A poética dramática inovadora de A. Tchékhov não ignorou os problemas de sua época, como discutido no capítulo anterior. Ao contrário, seus temas abordam as inquietações de uma sociedade e seus indivíduos em um século de profundas mudanças, em que o próprio tempo, motor implacável destas transformações, torna-se protagonista das obras.

Este novo conteúdo, no entanto, não se harmoniza com a forma dramática tradicional ainda utilizada pelo autor. O conflito interno das personagens ou o conflito entre a vida com a qual sonham e a vida que efetivamente levam, parece não mais caber em uma forma que prima por antagonismos exteriores, claramente definidos.

Ao abordar questões pertinentes as suas épocas, Tchékhov e os demais autores do "drama novo", embora não tenham rompido totalmente com o cânone que os precedia, adotaram procedimentos inovadores, contrários às "peças-bem-feitas", herdeiras do drama burguês e do drama romântico, que ainda obtinham grande sucesso entre os espectadores/leitores europeus e russos da época.

O nascimento do drama, segundo Peter Szondi, dá-se no Renascimento, quando o homem teve "a audácia de construir, partindo unicamente da reprodução das relações intersubjetivas, a realidade da obra na qual quis se determinar e espelhar" (SZONDI, 2001, p. 29). Para Hegel, que situa o drama entre a tragédia e a comédia, o drama da época moderna nasce a partir da ideia de que "apesar dos desacordos e dos conflitos de interesses, paixões e caracteres, é possível criar uma realidade harmoniosa mediante a atividade humana" (HEGEL, 1993, p. 651). Ainda segundo o filósofo alemão, o drama tem por objetivo a celebração do triunfo da moral, onde os maus são punidos e a bondade exaltada (HEGEL, 1993, p. 665).

Instituindo-se contra os princípios da tragédia clássica e redefinindo-os, o drama burguês surgido no século XVIII buscava a eliminação da distância social entre personagens e plateia (SZONDI, 2005, p. 36) e seus consequentes desdobramentos: o espaço público característico da tragédia clássica dá lugar ao privado; os problemas que movem a ação

\footnotetext{
${ }^{37}$ 2010, p. 293.
} 
passam a ser de ordem exclusivamente íntima; a família torna-se eixo central das obras. $\mathrm{O}$ terror e piedade que deveriam ser purgados pela tragédia clássica são substituídos por uma busca pela sentimentalidade, que também une, através das lágrimas, palco e plateia.

Assim, a consciência trágica dá lugar ao surgimento de uma moralidade, que tendeu na história da dramaturgia ocidental a uma simplificação e a uma divisão entre bons e maus, entre heróis e vilões, e que culminou no melodrama ${ }^{38}$. Para Richard Gilman (1923-2006), crítico literário norte-americano,

enquanto os trágicos viam o desastre como uma condição inerente à existência, e a vitória como nobre reconhecimento e coragem em aceitar tal catástrofe, o drama burguês dos séculos XVIII e XIX transformou o destino em uma questão de presença ou ausência de virtude, de sorte, de condições sociais, de força ou fraqueza pessoal; as personagens dramáticas tornaram-se encarnações do "sucesso" ou do "fracasso" (GILMAN, 1975, p. 142-143).

Foi também contra esta convenção que os autores do "drama novo" se colocaram. Em suas obras as personagens estão longe de se configurarem como heróis ou vilões, tornando-se multidimensionais. No caso da dramaturgia de Tchékhov fica ainda evidente que sobre as personagens não recai qualquer juízo de valores. O próprio autor declarou em carta ao editor Suvórin:

Separar as pessoas em bem-sucedidas e malsucedidas é olhar para a natureza do ser humano por um prisma estreito e preconcebido... Você é bem ou malsucedido? E eu? E Napoleão? E o seu Vassíli? Onde está o critério, aqui? Seria preciso ser Deus para saber diferenciar os bem-sucedidos dos fracassados, sem errar [...] (TCHÉKHOV, 2002a, p. 97).

Desta forma, os destinos das personagens não são, para o autor russo, uma questão de virtude ou fraqueza, mas consequência de um acúmulo de experiências, sempre em conexão com um universo muito mais amplo, onde as atitudes de cada personagem (ou a omissão destas) contribuem para uma cadeia geral de acontecimentos ou, paradoxalmente, com a falta destes. Há na poética dramática tchekhoviana um complexo sistema de interdependência; como se a felicidade de cada personagem dependesse não somente dela, mas também de cada

\footnotetext{
${ }^{38}$ De acordo com o pesquisador francês Patrice Pavis, o melodrama surge no século XVIII, como uma peça popular que mostra situações apavorantes ou enternecedoras, visando à comoção fácil do público. As personagens, "não têm nenhuma opção trágica possível; elas são poços de bons ou maus sentimentos, de certezas e evidências que não sofrem contradição. Seus sentimentos e discursos, exagerados até o limite do paródico, favorecem no espectador uma identificação fácil e uma catarse barata" (PAVIS, 2008, p. 238-239).
} 
uma das outras, das relações que estabelecem, ou até mesmo da condição financeira e do clima - tudo está relacionado entre si, tudo depende de tudo, como na própria vida.

Tchékhov instaura assim, uma poética do cotidiano, em que os acontecimentos não mudam o rumo da vida; conflitos são expostos, mas não resolvidos. O drama passa a se constituir do "não-dramático", do lugar comum, opondo-se à tradição dramática dos gregos, das tragédias clássicas francesas, de Shakespeare e de qualquer outra dramaturgia que organiza o mundo "em ficções sistemáticas e hiperbólicas, que o exagera e o transforma em lenda" (GILMAN, 1975, p. 121).

Acreditamos que as inovações do sistema dramático tchekhoviano, originadas da contradição entre a forma tradicional ainda utilizada pelo autor e o novo conteúdo abordado, podem ser entendidas como a emersão de elementos épicos e líricos dentro da forma dramática, ou ainda, como definiu o filósofo e crítico literário russo Mikhail Bakhtin, como reflexos da "romantização" sofrida pelo próprio gênero dramático. Mesmo que a forma não tenha se descaracterizado completamente, sofreu transformações profundas decorrentes da tensão provocada pelos novos conteúdos. O reflexo direto desta tensão pode ser encontrado nos problemas de comunicação entre as personagens, procedimento de que Tchékhov se utiliza na criação de um novo paradigma em sua poética dramática.

Para melhor compreender as inovações propostas pelo autor, gostaríamos de recapitular os principais pontos da teoria dos gêneros literários, principalmente as definições atribuídas ao gênero dramático.

Aspectos gerais da teoria dos gêneros literários

Como se sabe, a classificação das obras literárias segundo gêneros tem início em $A$ República de Platão. Em sua Poética Aristóteles aborda os gêneros épico e dramático e ao referir-se aos ditirambos ${ }^{39}$ apresenta também o que mais tarde configurou-se como gênero lírico. Segundo o filósofo grego, os três gêneros tratam de imitações, que se diferem pelos meios, objeto ou modo com que imitam (ARISTÓTELES, s.d., p. 239). No gênero épico distingue-se a presença de um narrador, ausente nos outros dois; no gênero dramático, as personagens estão sempre em ação, diante de nós. Aristóteles (s.d., p. 142) difere ainda a

\footnotetext{
${ }^{39}$ Poesia coral em honra a Dionísio, acompanhada de dança, mímica e música, a qual se atribui a origem da tragédia ática.
} 
imitação dos atos das personagens que se dividem pela prática da virtude ou do vício. A mesma diferença separaria a tragédia da comédia - a primeira pretende imitar os homens representando-os piores, a segunda representando-os melhores.

O filósofo grego nota que a imitação de uma ação no gênero dramático deve ser completa, una e total, de modo que todas as partes sejam indispensáveis; devem estar de tal modo conectadas "que baste a suspensão ou o deslocamento de uma só, para que o conjunto fique modificado ou confundido [...]" (ARISTÓTELES, s.d., p. 251). A unidade de ação proposta por Aristóteles é uma das características principais que definem o gênero dramático em sua concepção.

O termo "sistema dramático aristotélico" utilizado na presente dissertação refere-se às definições do gênero dramático dadas pelo filósofo, em que se destaca o encadeamento lógico das ações, organizadas por relações de causa e efeito, regentes também do diálogo entre as personagens.

Retomando a teoria dos gêneros literários em sua Estética, G.W.F. Hegel sublinha a importância da unidade de ação no gênero dramático, como proposta por Aristóteles. Hegel ilumina este último como síntese entre os gêneros épico e lírico, razão pela qual, para o filósofo alemão, o gênero dramático seria "superior" aos outros dois (HEGEL, 1993, p. 569).

Sobre o gênero épico, Hegel nota que o conjunto da concepção do mundo e da vida de uma nação se apresenta sob a forma objetiva de acontecimentos reais, em que uma grande proeza é descrita em todas as suas fases, com grande amplitude poética, assim como as personagens que dela participam (HEGEL, 1993, p. 573). O poeta, enquanto sujeito, deve "desaparecer", para que sejam realçados os fatos e acontecimentos concretos, sempre ligados a um passado heroico.

Para o filósofo, a poesia épica nasce "do prazer de ouvir o relato de uma ação estranha que se desenrola, na forma de uma totalidade objetiva completa, ante a consciência do ouvinte" (HEGEL, 1993, p. 608). Não há, portanto, a "pressa dramática", sempre ávida por fins e resultados, o que permite uma contemplação tranquila e pormenorizada de cada quadro, que por sua vez está organicamente conectado à totalidade da obra. A ação que se sucedeu em um passado longínquo encontra-se perfeitamente acabada, polida, lapidada.

Quando as visões de mundo do homem individual separam-se daquelas do estado, quando, no próprio homem "se efetuou a separação entre vontade e sentimento" (HEGEL, 1993, p. 573), a poesia épica, segundo o filósofo alemão, dá lugar à lírica e por vezes à dramática. 
O gênero lírico situa-se, na concepção hegeliana, em oposição ao épico, já que seu traço fundamental é a expressão subjetiva, a revelação da alma do poeta, que em vez de agir, "persiste na sua interioridade e não pode por consequência ter por forma e por fim senão a expansão do sujeito, a sua expressão" (HEGEL, 1993, p. 569). Assim, o conteúdo do gênero lírico concentra-se nas transformações da própria alma do poeta e da consciência que adquire de si mesma, através dos sentimentos e sensações que experimenta. As palavras frequentemente empenham-se na construção de imagens e adquirem traços musicais, ganhando melodia e aproximando-se de um verdadeiro canto.

O gênero dramático, por sua vez, reúne de acordo com Hegel, os dois outros gêneros para formar uma nova totalidade,

que comporta um desenvolvimento objetivo e nos faz assistir ao mesmo tempo à manifestação dos acontecimentos da interioridade individual, de modo que o objetivo se apresenta como inseparável do sujeito, enquanto que o subjetivo, pela sua realização exterior e pela maneira como é entendido, faz surgir paixões que o animam como sendo uma consequência direta e necessária do que o sujeito é e faz (HEGEL, 1993, p. 569).

Desta maneira, o gênero dramático para Hegel une à forma objetiva de acontecimentos, característica do gênero épico, a expressão da subjetividade, traço do gênero lírico. A ação que se apresenta no gênero dramático não se localiza no passado, mas dá-se no momento presente, vivificada pela subjetividade das personagens agentes, em constante embate de vontade e paixões. Como no gênero épico, vemos uma ação impulsionada por conflitos até seu desfecho, e presenciamos, como no gênero lírico, a ação "enquanto se vem originando atualmente, como expressão imediata de sujeitos" (ROSENFELD, 2010, p. 29, grifo do autor). O conflito, portanto, torna-se palavra-chave para o gênero dramático na concepção hegeliana, desencadeando novas ações e reações até que se produza o apaziguamento final. Hegel (1993, p. 631) destaca ainda a impossibilidade das personagens permanecerem encerradas em si mesmas: motivadas por suas paixões e objetivos, enfrentam obstáculos impostos pelas circunstâncias presentes e estão em oposição e luta com outras personagens.

Assim, ação e tempo presente somam-se ao diálogo, o modo de expressão dramático por excelência, para compor a tríade que sustenta o gênero dramático na compreensão hegeliana.

Sobre a ação, sempre apresentada como real, no tempo presente, pode tanto derivar do caráter íntimo das personagens que a efetuam, como também pode ser resultado dos fins e 
conflitos que a acompanham ou que ela mesma provoca. O movimento real impresso à ação é dado pelo diálogo, no qual as personagens revelam umas às outras seus objetivos e exprimem suas discordâncias.

Ainda em sua Estética, Hegel proclama que na obra artística o conteúdo e a forma devem ser idênticos ${ }^{40}$. No caso do gênero dramático, a objetividade da forma, ou seja, a realização exterior de acontecimentos, expressos através dos diálogos, deve corresponder ao seu conteúdo interno, originado pela subjetividade das personagens, em luta para a realização de suas paixões.

Em Teoria do drama moderno [1880-1950] (2001) Peter Szondi examina obras da dramaturgia moderna (incluindo-se as peças de Tchékhov) nas quais forma e conteúdo já não são correspondentes, pois apresentam entre si contradições, uma vez que o conteúdo, pelos novos temas que os autores começam a tratar, passa a questionar a forma. Szondi, portanto, retoma a teoria dos gêneros literários, mas examina na dialética entre forma e conteúdo, como o drama tentou representar a realidade histórica de seu tempo.

O teórico literário russo Boris Tomachévski também ressalta que a dimensão dos gêneros é sempre histórica, "justificada unicamente por certo tempo" (TOMACHEVSKI, 1973, p. 203), reiterando que não há pureza de gêneros, já que os traços estilísticos de cada um deles podem se agregar à natureza inteiramente diversa de outro, pois sua distribuição "não obedece senão às leis internas da composição estética" (TOMACHEVSKI, 1973, p. 203). A verdadeira obra artística para Tomachévski recusa-se à mera repetição de procedimentos anteriores, evoluindo através da "desautomatização" destes mesmos procedimentos e hábitos, mesmo que estes causem, a princípio, estranhamento por seu ineditismo. As formas literárias, portanto, reagem à complexidade da própria vida, revelando a relação homem-sociedade.

Anatol Rosenfeld (2010, p. 16) também nota que a pureza dos gêneros literários não existe em sentido absoluto e nem deve ser objetivo a ser alcançado pelos autores, mas sim, uma etapa importante para os estudos literários. O autor, inclusive, tece duas acepções diferentes para a teoria - uma primeira "substantiva", que trata dos gêneros em si, e outra "adjetiva", que se refere aos traços estilísticos que podem permear cada um deles. Estes traços seriam um reflexo da situação histórico-social de cada período, o que equivale a dizer, uma adaptação "à temática proposta pela respectiva época" (ROSENFELD, 2010, p. 32).

\footnotetext{
${ }^{40}$ Cf. seção C. Os diferentes Gêneros Poéticos / Introdução e Repartição (HEGEL, 1993, p. 568-629).
} 
A fim de esclarecer as inovações propostas por Tchékhov, os termos "gênero/sistema dramático rigoroso", "gênero/sistema dramático tradicional" usados na dissertação, referem-se aos traços peculiares que caracterizam este gênero, ainda que de forma absoluta.

No intuito de compreender a literatura como um fenômeno estético articulado a um contexto cultural mais amplo, Mikhail Bakhtin também questiona a pureza dos gêneros literários e sua teoria clássica.

Em Epos e romance (1993), Bakhtin debruça-se sobre a metodologia do estudo do romance, observando que este é o único gênero em devir, construído na zona de contato direto com o presente inacabado e que evolui em meio a outros gêneros já consolidados. Por sua relação direta com o tempo presente, por seu diálogo com a época que se faz "agora", o romance, segundo Bakhtin, põe em crise o próprio conceito de gênero como formação estável e lança-se como personagem principal da evolução literária.

Uma das consequências imediatas da "supremacia" do romance ainda segundo o teórico literário, é a "romantização" em maior ou menor grau, de todos os outros gêneros, incluindo-se o dramático:

O romance é o único gênero em evolução, por isso ele reflete mais profundamente, mais substancialmente, mais sensivelmente e mais rapidamente a evolução da própria realidade. [...] Deste modo, tornando-se o senhor, ele contribui para a renovação de todos os outros gêneros, ele os contaminou e os contamina por meio da sua evolução e pelo seu próprio inacabamento (BAKHTIN, 1993, p. 400).

Bakhtin ressalta que a "romantização" dos outros gêneros não implica a sua submissão a modelos estranhos, mas ao contrário:

trata-se de liberá-los de tudo aquilo que é convencional, necrosado, empolado e amorfo, de tudo aquilo que freia sua própria evolução e tudo aquilo que os transforma, ao lado do romance, em estilizações de formas obsoletas (BAKHTIN, 1993, p. 427).

Desta maneira, pretende-se compreender como as alterações propostas por Tchékhov dialogam com a inserção de elementos característicos aos gêneros épico e lírico na forma dramática e como a consequência da "romantização" do gênero dramático proposta por Bakhtin reflete-se nas inovações da poética dramática tchekhoviana. 
Gostaríamos de ressaltar que as inserções de elementos épicos no sistema dramático de Tchékhov não devem ser confundidas com o termo "teatro épico", geralmente associado às concepções de Bertolt Brecht ${ }^{41}$ (1898-1956).

\section{Sobre o diálogo e a ação no gênero dramático rigoroso}

A forma dramática por excelência, o diálogo, como se sabe, realiza-se no gênero dramático tradicional como uma sucessão lógica de causa e efeito, em que cada réplica não nasce arbitrariamente, mas é rigidamente determinada pela anterior ${ }^{42}$. Da mesma maneira, desencadeia-se a ação dramática, sempre movida, ou antes, gerada pelo diálogo, que deve manifestar o embate de vontades contrárias. Ao examinar esta arquitetura da dramaturgia clássica, Anatol Rosenfeld resume: "O diálogo dramático move a ação através da dialética de afirmação e réplica, através do entrechoque das intenções" (ROSENFELD, 2010, p. 34).

Para Hegel esta é a norma ideal: o diálogo, alimentado pelo embate de vontades contrárias, deve gerar ação, que por sua vez está destinada a alterar a situação dramática presente. O diálogo que não provoca transformações, ou seja, no qual assuntos são discutidos sem interferência direta na ação dramática, é condenado pelo filósofo como um desvio não dramático (HEGEL, 1993, p. 635).

Desta maneira, o desenvolvimento do enredo no sistema dramático aristotélico dá-se através das ações, que devem ocorrer diante dos espectadores e apresentar princípio, meio e fim. Os acontecimentos estão entrelaçados, cada cena é consequência da anterior e suscita o nascimento da próxima, fazendo com que o mecanismo dramático mova-se por si, sem necessidade de qualquer mediação externa. Para Hegel, a ação nasce do conflito porque está sujeita "às circunstâncias, paixões e caracteres que se lhe opõem. Por sua vez, estes conflitos e oposições dão origem a ações e reações que, num determinado momento, produzem o necessário apaziguamento" (HEGEL, 1993, p. 630).

No sistema dramático tradicional, portanto, a matéria dos acontecimentos concentra-se e organiza-se em função de uma crise, uma tensão, isto é, a presença de um conflito é

\footnotetext{
${ }^{41}$ Dramaturgo, diretor, teórico e poeta alemão, foi um dos principais nomes do teatro do século XX, cunhando a partir de 1926, o termo "teatro épico".

${ }^{42}$ Cf. Aristóteles, capítulo VIII da Poética (Unidade de Ação).
} 
fundamental para que a ação dramática nasça e se desenvolva; nas palavras do pesquisador francês Patrice Pavis,

a ação está ligada ao surgimento e à resolução das contradições e conflitos entre as personagens e entre uma personagem e uma situação. É o desequilíbrio de um conflito que força a(s) personagem(s) a agirem para resolver a contradição; porém sua ação (sua reação) trará outros conflitos e contradições. Esta dinâmica incessante cria o movimento da peça. [...] (PAVIS, 2008, p. 4).

O conflito, um dos traços principais do gênero dramático, suscita movimento, faz com que o enredo avance ininterruptamente em busca de uma solução, já que "a coexistência prolongada de dois princípios opostos não é possível, e um dos dois deverá superpor-se" (TOMACHÉVSKI, 1973, p. 177). As vontades e/ou atitudes contrárias, manifestas através do diálogo, geram a ação, que se desenvolve no presente absoluto da arte dramática pura, um tempo linear e sucessivo, em que tudo acontece sempre "pela primeira vez", diante dos espectadores. Ao autor dramático cabe provocar cada vez mais conflitos, como sugere a imagem proposta pelo crítico e dramaturgo Eric Bentley (1916-), que o compara a um guarda de trânsito perverso, que ao invés de fazer com que os carros não se choquem, provoca justamente as colisões (BENTLEY, 1967, p. 42).

Assim, o gênero dramático tradicional se constrói sobre verbos (lembremos mesmo que o significado da palavra "drama" em grego é ação), gerados por conflitos, expressos através do diálogo, no tempo presente da cena representada. A unidade entre fala e movimento dramático é, portanto, indissolúvel.

O conjunto das ações organizado pelo autor através do enredo, no sistema dramático tradicional, deve ainda obedecer pelo menos às seguintes etapas, de acordo com Tomachévski (1973):

- Exposição (apresentação do ambiente, das personagens e das relações entre elas);

- Enlace (a introdução do motivo dinâmico que define o desenvolvimento da fábula, ou seja, a revelação dos conflitos, dos obstáculos que se impõem às personagens);

- Clímax (tensão máxima a que chega o desenvolvimento do conflito);

- Desenlace (resolução do conflito). 
Sobre a ação e o diálogo no sistema dramático tchekhoviano

Se no sistema dramático tradicional o diálogo, a forma dramática por excelência, é o veículo no qual se manifestam conflitos e vontades contrárias, é a mola propulsora que desencadeia acontecimentos, na poética dramática tchekhoviana ele deixa de exercer tais funções. O diálogo passa a expressar, ou paradoxalmente camuflar, as angústias, sonhos e desejos de personagens isoladas em seus mundos interiores, inaptas a compreender e serem compreendidas, seres que se refugiam nas memórias do passado ou nas expectativas quanto ao futuro. A tríade que havia sustentado o gênero dramático rigoroso - ação, diálogo e tempo presente - é, portanto, nas peças de Tchékhov, abalada.

Uma das primeiras transformações que notamos no sistema dramático tchekhoviano é a quebra da relação causa-efeito; Tchékhov liberta o diálogo da condição lógica aristotélica, réplicas e tréplicas não mais geram umas às outras, perguntas permanecem sem respostas, palavras pairam no ar em suspensão e as reticências muitas vezes substituem os pontos finais. Para Vladímir Nabókov, a realização de Tchékhov foi justamente a de "mostrar o caminho certo para se escapar do cárcere da causalidade determinística, da causa e do efeito, e romper com as barreiras que mantinham o drama prisioneiro" (NABOKOV, 1981, p. 285).

Na cena de abertura de $O$ tio Vânia, por exemplo, o diálogo entre a velha babá Marina e o doutor Ástrov, médico chamado à propriedade para examinar o professor Serebriakov, está concentrado no estabelecimento de uma atmosfera dominada pela memória, em que são evocadas as transformações ocorridas até o presente:

MARINA (servindo uma xícara de chá): Beba, querido irmãozinho.

ÁSTROV (aceita a contragosto): Não estou com muita vontade.

MARINA: Então talvez um pouco de vodca?

ÁSTROV: Também não. Não bebo vodca todos os dias. Além do mais o ar está sufocante. (Pausa) Babá, há quanto tempo nos conhecemos?

MARINA (pensando): Quanto? Oh, meu Deus... Deixe-me pensar um pouquinho. Quando você chegou aqui, a estas paragens... quando foi mesmo?... Vera Petrovna, mãe de Sónetchka ainda estava viva. Você nos visitou por dois invernos, antes de ela morrer. Sendo assim, há onze anos. (Depois de refletir) Mas pode ser até mais...

ÁSTROV: Mudei muito de lá para cá?

MARINA: Bastante. Você então era jovem, bonito, e agora envelheceu. Nem sua beleza não é mais a mesma. E, verdade seja dita - você bebe.

ÁSTROV: Sim... Nestes dez anos virei outra pessoa. E sabe por quê? De tanto trabalhar, babá [...] (TCHÉKHOV, 1998b, p. 69). 
Surpreendentemente, já neste pequeno trecho inicial, Tchékhov abre os principais temas da obra: o passar do tempo, a vida exaustiva na província, a beleza finita e o trabalho. Indicando também as ações das personagens nas rubricas (Marina, com movimentos lentos, tricota uma meia e Ástrov perto dela anda de um lado para o outro) e o tempo e lugar da ação (estão no jardim, debaixo de velhos álamos, com uma mesa posta para o chá; bancos, violão e um balanço não muito longe; são três da tarde, tempo encoberto), Tchékhov instaura detalhadamente o ambiente da obra. Os conflitos presentes nas "cenas da vida rural em quatro atos" são já neste trecho sutilmente propostos: o trabalho que consome Ástrov contrasta com a ociosidade sugerida pelo balanço e pelo violão; a sombra das velhas árvores, presença da natureza sábia, opõe-se ao ar "sufocante" do presente; a aceitação paciente dos mais velhos destaca-se das inquietações dos mais jovens.

Neste sentido, o encadeamento aristotélico de ações e diálogos dá lugar a uma dramaturgia que privilegia o fluxo da própria vida. O enredo deixa de ser estruturado por acontecimentos dramáticos para seguir os movimentos de alma de cada personagem, que Tchékhov, como poucos dramaturgos, colore com infinitos matizes. Ainda que o autor não rompa totalmente com os elementos que constroem o enredo do sistema dramático tradicional, instaura mudanças significativas, que provocaram estranhamento nos leitores/espectadores da época pelo seu ineditismo.

Embora os enredos sejam bastante diferentes, nas quatro peças analisadas, apresentamse estruturas semelhantes. O diretor Adolf Shapiro no estudo cênico Tchékhov ${ }^{4}$, optou por encenar um ato de cada uma das quatro peças justamente por suas construções análogas.

Todos os primeiros atos apresentam a chegada de visitantes que estão de passagem e nos segundos atos, as consequências provocadas por estas alterações de rotina já estão em pleno movimento. Se os conflitos começam a ser descortinados já a partir do primeiro ato, no segundo fica claro que não se pode fugir deles: em $O$ jardim das cerejeiras o leilão da propriedade já tem data marcada; em O tio Vânia já estão traçadas as paixões e os desejos de cada personagem em oposição à realidade em que vivem, assim como em A gaivota. $\mathrm{O}$ enlace, pela própria natureza do conflito na obra tchekhoviana - muito mais presente na diferença entre o mundo interior das personagens e a realidade em que vivem, múltiplo pela própria pluralidade de personagens em cena e sem desdobrar ações e diálogos sequenciais não está concentrado em um único momento, mas ecoa durante todos os atos. O desejo de ir a Moscou se expressa logo nas primeiras linhas de As três irmãs e a impossibilidade de realizálo se concretiza ao longo dos três primeiros atos, pela própria passagem do tempo. O clímax não tem mais o suspense como apresentado na dramaturgia tradicional, pois não há a 
culminação das tensões originadas pelo conflito exterior, não há expectativas centradas em acontecimentos, assim como não há antagonistas diretos; por certo, os terceiros atos das peças de Tchékhov são sempre os mais agitados - tudo explode, pois a contradição entre a vida que se deseja e a realidade alcança o ponto máximo. Há, porém, muito mais um desgaste emocional enfrentado pelas personagens, cada uma consigo mesma ou com o tempo presente, com a realidade que não conseguem transformar, do que uma culminação "insustentável" do choque provocado pelo conflito externo, como aconteceria no sistema dramático tradicional.

Em A gaivota, é precisamente no terceiro ato que se dá o encontro entre Arkádina e Tréplev, após a fracassada apresentação no início da obra. O embate entre velhas e novas formas atinge seu ponto máximo no diálogo entre ambos, para logo em seguida ser afrouxado pela partida de Arkádina e Trigórin. Em $O$ tio Vânia, a angústia do protagonista também alcança seu ápice no terceiro ato, ao receber a proposta de Serebriakov de vender a propriedade. Trabalhando anos a fio para saldar as dívidas da fazenda, sempre com admiração ao trabalho do professor, a lucidez de Voinítskii (a personagem-título) culmina com sua breve perda da razão. A consciência de uma vida desperdiçada, o exaustivo trabalho e a rígida economia dedicados a um homem que agora considera uma "nulidade", culminam nos disparos dados pelo tio Vânia em Serebriakov. Em As três irmãs, o desgaste emocional das personagens, refletido no incêndio que se vislumbra das janelas, também se revela pela consciência desesperadora que ilumina as personagens. Nas falas de Irina, a explosão de sentimentos parece ser deflagrada por um pequeno detalhe, o "esquecimento", que metaforiza a sensação de exílio a que estão condenadas:

IRINA: Onde tudo foi parar? Onde foi parar? Onde? Meu Deus, meu Deus! Esqueci tudo, tudo! Na minha cabeça está tudo embaralhado... Não sei mais como se diz em italiano "janela" ou "teto"... Esqueço tudo, cada dia mais e mais, e a vida se esvai, e nunca voltará, nunca mais. Nunca iremos a Moscou... Sinto que nós nunca sairemos daqui (TCHÉKHOV, 2006b, p. 48). 


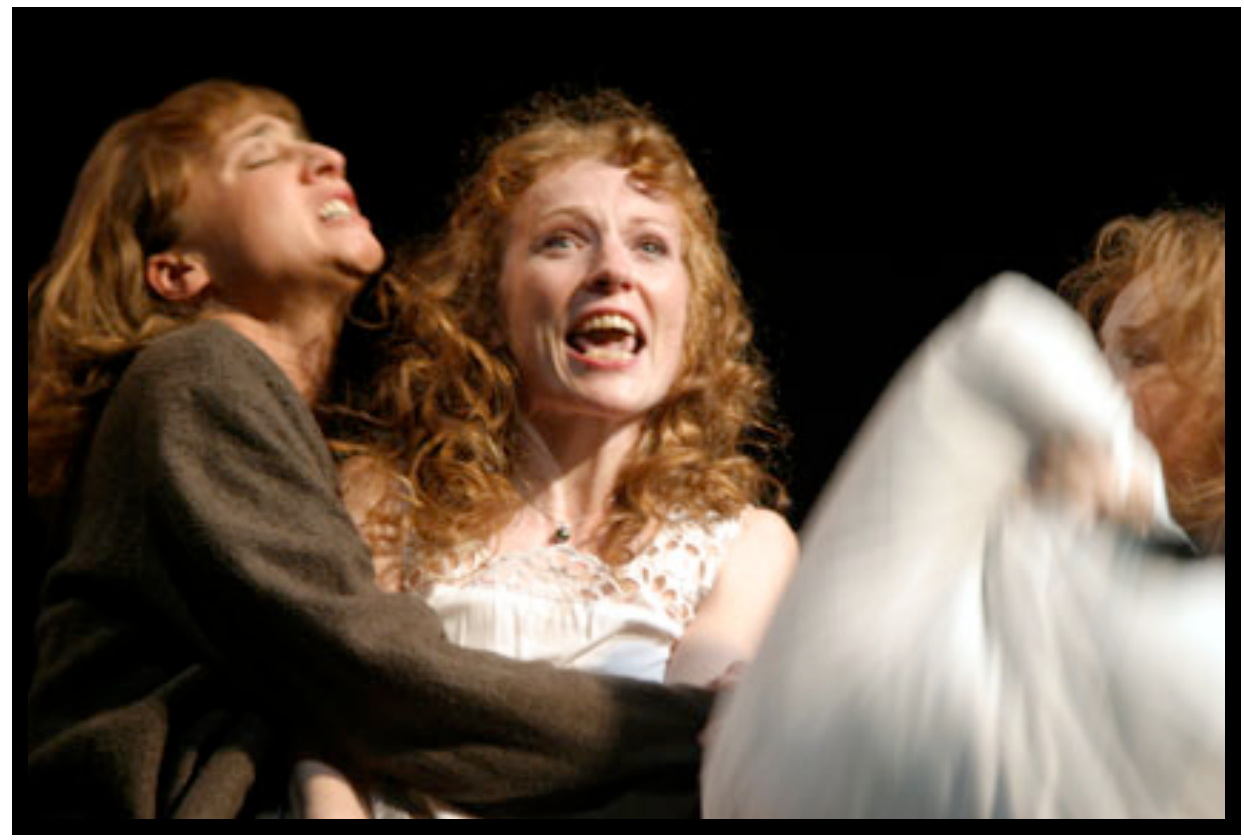

As três irmãs (2004) montagem de Piotr Fomenko. Olga (Galina Tiunina), Irina (Ksénia Kutépova) e Macha (Pauline Kutépova). Foto: Ekaterina Tsvetkov ${ }^{43}$.

Embora este não seja o fim da obra, que Tchékhov estende por mais um ato, Irina adquire consciência de sua condição, em que o cotidiano "gasto" acinzenta sonhos e desejos. Com a passagem do tempo o trabalho, que representava para ela a possibilidade de transformação de sua vida e da realidade da província, também se acinzenta, torna-se vazio. É esta lucidez que transborda no terceiro ato:

IRINA (controla-se): Oh, que desgraçada eu sou... Não sei trabalhar, não vou mais trabalhar. Chega, chega! Trabalhei nos correios, agora trabalho na prefeitura e detesto, desprezo meu trabalho... Completei vinte e três anos, trabalho há muito tempo e os meus miolos estão secando, emagreci, enfeei, estou também envelhecendo, e não vejo recompensa alguma! No entanto o tempo passa e sinto que cada vez mais e mais me distancio da vida bela e verdadeira e me aproximo de algum abismo. Estou desesperada, e não compreendo como ainda estou viva, como ainda não acabei com a minha vida, não compreendo (TCHÉKHOV, 2006b, p. 48).

Além da explosão de Irina, no terceiro ato Macha confessa às irmãs seu amor por Verchínin, Olga aconselha Irina a casar-se com o barão Tusenbach mesmo sem amor e Andrei finalmente compreende a falta de intersecção entre o mundo das irmãs e da esposa:

ANDREI: [...] Em primeiro lugar, vocês têm algo contra Natacha, minha mulher, vejo isto desde o dia de nosso casamento. Natacha é uma pessoa excelente, honrada, uma alma franca e nobre - essa é a minha opinião. Amo

\footnotetext{
${ }^{43}$ Foto disponível em: www.fomenko.theatre.ru. Acesso: 03 dez. 2010.
} 
a minha mulher, respeito-a - entendem? - respeito-a e exijo dos outros que também a respeitem, repito, é uma mulher excelente e honrada, e vocês estão amuadas assim apenas, perdoem-me, por capricho. (Pausa) Em segundo lugar, parece-me que vocês estão zangadas por eu não ter me tornado professor universitário e não ter seguido a carreira científica. Porém eu trabalho na prefeitura, sou membro do conselho municipal e considero meu cargo tão sagrado e tão importante como qualquer carreira científica. Sim, eu sou membro do conselho, e, se quiserem saber, tenho orgulho disso... (Pausa) E em terceiro lugar... quero dizer ainda... É que... hipotequei a casa sem o consentimento de vocês... Pois bem, sinto-me culpado por isso, e peço-lhes que me perdoem... Minhas dívidas me obrigavam a fazer isso. Trinta e cinco mil. Deixei de jogar há muito, mas o que sobretudo me serve de justificativa é que vocês, por serem mulheres, recebem uma pensão, enquanto eu... praticamente não tinha rendimento algum... (Pausa) [...]

Elas não me ouvem. [...] Queridas irmãs, queridas e boas irmãs, não acreditem em mim, não acreditem!... (Sai) (TCHÉKHOV, 2006b, p. 50-51).

A confissão de Andrei tem seu caráter monológico reforçado pela ausência de resposta das irmãs, que o próprio Andrei percebe - "elas não me ouvem"; em meio à confusão do incêndio, limitadas no pequeno quarto que agora dividem, Olga e Irina permanecem em silêncio. Como diferentes instrumentos de uma sinfonia, as demais personagens executam cada qual seu tema: Kulíguin em diversas aparições procura incessantemente a esposa Macha; Tchebutíkin fica bêbado; o funcionário Ferapont busca Andrei para que este assine documentos; Natacha, inspecionando toda a casa, atravessa a cena com uma vela.

Ainda que o ápice, os momentos mais conflituosos e desgastantes sejam enfrentados nos terceiros atos, Tchékhov prolonga suas obras, deixando que o fluxo da vida se sobreponha aos acontecimentos do enredo, fazendo com que as peças se abram para o infinito e deixando ao leitor/espectador uma sensação de inacabamento. Embora a venda da propriedade seja concluída no terceiro ato de O jardim das cerejeiras, por exemplo, Tchékhov não permite que o desenlace coincida com o fim da obra. Ao construir mais um ato, o autor reforça a ideia de que a vida continua e de que a rotina das personagens foi alterada por certo período. Há uma relação de simetria entre o início e o fim de cada peça, em que a partida das personagens ecoa a chegada no primeiro ato. Ainda em $O$ jardim das cerejeiras, temos no primeiro ato, a alegria da chegada:

LIUBOV ANDRÉIEVNA (olha pela janela): Oh, minha infância, minha pureza! Eu dormia neste quarto, daqui olhava o jardim. Toda manhã a felicidade acordava junto comigo, e o jardim continua igualzinho ao que era, não mudou nada! (TCHÉKHOV, 2006b, p. 80). 
O fim da peça é marcado pela despedida, esperançosa para as personagens jovens que saúdam o futuro, lírica para aqueles que, de uma vez por todas, foram obrigados a deixar o passado:

LIUBOV ANDRÉIEVNA: Oh, meu belo, maravilhoso e querido jardim! Minha vida... minha juventude... Adeus. Adeus! (TCHÉKHOV, 2006b, p. 119).

Destaca-se, portanto, o percurso de cada personagem dentro da estrutura de cada obra, no lugar dos acontecimentos do enredo. Assim, o "crescendo" ininterrupto de ações encadeadas linearmente dá lugar a ondas de agitação e repouso, que assumem a fluência da estrutura dramática. O movimento das personagens em busca de seus ideais surge e se esvai, adormece, para ressurgir adiante, em uma espiral infinita, mostrando que o deslocamento, o percurso em si é mais importante que o ideal que o motivou. Tchékhov, desta maneira, retrata indivíduos e sociedades em um estado de perpétua mudança - como o definiu o diretor inglês Peter Brook, Tchékhov é "o dramaturgo do movimento da vida" (BROOK, 1994, p. 214).

Dentro dessa estrutura o diálogo, suporte do gênero dramático e de cuja possibilidade depende o próprio gênero, é ameaçado e passa a exercer novas funções. Ao invés de gerar acontecimentos, o diálogo expressa a individualização da linguagem de personagens isoladas pela solidão e enclausuradas em seus mundos interiores:

LIUBOV ANDRÉIEVNA: [...] E a nossa Vária também continua a mesma, como uma freirinha... Também a Duniacha reconheci imediatamente... (Beija Duniacha também).

GÁIEV: O trem atrasou exatamente duas horas, não é? Bela situação.

CHARLOTTA (a Pischtik): Meu cachorrinho come até nozes! (TCHÉKHOV, 2006b, p. 71).

Neste trecho, uma das cenas iniciais de O jardim das cerejeiras, réplicas e tréplicas são desconexas, independentes, como colagens aleatórias das impressões e pensamentos de cada personagem; poderíamos mesmo inverter a ordem de cada uma delas sem prejuízo de entendimento, o que seria impossível no sistema dramático tradicional. A independência de cada réplica denota também a falta de escuta entre as personagens, que muitas vezes fechadas em seus mundos individuais, recusam à comunicação.

A ausência de vontades contrárias, a falta de enfrentamentos que impulsionariam o diálogo e por consequência a ação, também se evidencia. As réplicas, portanto, não estão ligadas aos acontecimentos que impulsionariam o avanço do enredo, mas criam um universo, 
adquirindo uma dimensão poética e muitas vezes simbólica. O drama tchekhoviano apresentase assim, como uma sobreposição de temas cotidianos, recortes da vida, nos quais a falta de acontecimentos passa a ser o próprio drama. O material temático trivial, muito próximo aos leitores e espectadores, dispensa o conflito externo como centro do gênero dramático para dar lugar ao drama do indivíduo.

O conflito, portanto, passa do exterior para o interior, encontra-se no "espírito", é um conflito da personagem consigo mesma, ou ainda, da personagem com a realidade em que vive. A nova natureza do conflito na poética dramática tchekhoviana, consequentemente, não se exterioriza em antagonistas. Entre as personagens há um conflito de entendimentos diferentes do mundo, há uma multiplicidade de verdades, ninguém está errado ou é culpado.

A internalização do conflito evidencia a importância do subtexto tchekhoviano, do que Konstantin Stanislávski denominou por "corrente submarina": aquilo que está "além" das palavras, mas que deve estar claramente compreendido e assimilado pela encenação e interpretação dos atores, pois é a própria respiração da obra. As palavras surgem como a ponta de um imenso iceberg, sob o qual as vontades e angústias das personagens se amontoam em inúmeras camadas.

São precisamente estas camadas que formam o universo particular de cada personagem e a relação entre estes diferentes universos, um dos aspectos fundamentais da dramaturgia tchekhoviana. A este respeito a pesquisadora Nair D'Agostini salienta o entendimento de Stanislávski das inovações propostas por Tchékhov:

O mestre entende que, nas obras de Tchékhov, consideradas complexas, a fábula e os fatos não constituem seu maior significado, pois são as relações que se convertem em núcleo e essência da obra, criando a linha condutora do espetáculo, enquanto os acontecimentos são necessários como suporte para originar o conteúdo interno, expressar o conflito das personagens (D'AGOSTINI, 2007, p. 44).

O próprio Tchékhov, em carta ao irmão Aleksandr, também escritor, em abril de 1889, deixava claro que os acontecimentos não deveriam ser o centro da obra, mas que o ineditismo deveria se concentrar no próprio enredo, na maneira como o autor articula o conjunto da obra:

Lembre-se também de que as declarações de amor, as traições de mulheres e maridos, as lágrimas de viúvas, de órfãos e de outros mais, já foram descritas há muito tempo. $\mathrm{O}$ enredo deve ser novo, ao passo que a fábula pode estar ausente (apud ANGELIDES, 1995, p.136). 
Os grandes acontecimentos inclusive, no teatro tchekhoviano, se dão nos bastidores: o suicídio de Tréplev ( gaivota), o duelo entre Solióni e Tusenbach (As três irmãs), o leilão da propriedade (O jardim das cerejeiras), a disputa entre Serebriakov e Voinítskii ( $O$ tio Vânia). $\mathrm{O}$ autor, portanto, prioriza as relações e os mundos interiores de cada personagem ante os acontecimentos dramáticos, avivando as reações e transformações sofridas por elas, suas trajetórias dentro do espaço e tempo de cada obra.

Interessante notar que observação semelhante foi ressaltada pela pesquisadora Tereza de Menezes acerca das inovações estabelecidas pela dramaturgia de Henrik Ibsen, um dos pioneiros do "drama novo", mais precisamente sobre O pato selvagem (1884):

\begin{abstract}
A grande mudança em relação às peças-bem-construídas é que não se trata mais de justapor ou concatenar fatos para tornar a intriga atrativa; trata-se de revelar formas de relacionamento que subjazem às ações executadas, permitindo ao público fazer parte da atmosfera que se respira naquela família, mesmo que não consiga colocar isso em palavras (MENEZES, 2006, p. 62).
\end{abstract}

Nas peças de Ibsen os acontecimentos também deixam o centro do drama, pois os motivos que os causaram e o próprio tempo são mais importantes do que eles. A interioridade das personagens deve assumir o primeiro plano das peças de Ibsen, nas quais o próprio mundo do século XIX é colocado em questão, por meio "do conflito entre gerações, da ruptura entre passado e futuro e da nostalgia por uma autenticidade real ou utópica" (TOLMACHIÓV, 2010, p. 1).

Cerca de um século depois de Tchékhov e Ibsen a questão é ainda pertinente, como se observa no depoimento do cineasta Andriêi Tarkóvski, cujos filmes ficaram famosos pela potência das imagens, organizadas não por uma lógica linear, aristotélica, de acontecimentos sequenciais, mas pela "lógica da poesia":

Não estou interessado no desenvolvimento do enredo, na mudança de eventos. A cada filme, eu sinto cada vez menos necessidade deles. Sempre me interessei mais pelo universo das pessoas e, para mim, era muito natural fazer uma viagem dentro da psicologia que dera forma à atitude do herói para com a vida, dentro das tradições literárias e culturais que são a fundação de seu mundo espiritual. Estou interessado no homem que contém o universo dentro de si mesmo. E a fim de encontrar expressão para a ideia, para o significado da vida humana. Não há necessidade de um pano de fundo repleto de acontecimentos ${ }^{44}$.

${ }^{44}$ TARKÓVSKI, Andrei. Entrevista. In: DOSSIÊ TARKOVSKI VOL. IV (Stálker + Nostalgia + Sacrifício). Trad. Ellen Nagai. São Paulo: Continetal Home Video. DVD (123 min). 
Assim como as inovações da dramaturgia de Tchékhov foram criticadas, os filmes de Tarkóvski não lhe renderam apenas a emoção de espectadores altamente afetados pelas obras, como muitos expressaram em cartas ao cineasta, mas também foi alvo do desagrado de um público ainda acostumado à condução rigorosa de obras estruturadas em acontecimentos, perfeitamente encadeados pelas relações de causa e efeito.

O cineasta não ignorava tal fato, acreditava porém, no dever do artista em respeitar a inteligência de seu público e a função da arte em educá-lo:

Se tentarmos agradar o público, aceitando acriticamente suas preferências, isso significará apenas que não temos respeito algum por ele, que só queremos o seu dinheiro. Em vez de educarmos o espectador através de obras de arte inspiradoras, estaremos apenas ensinando o artista a garantir seu lucro. De sua parte, o público - satisfeito com aquilo que lhe dá prazer continuará firme na convicção de estar certo, uma convicção no mais das vezes sem fundamento. Deixar de desenvolver a capacidade crítica do público equivale a tratá-los com total indiferença (TARKOVSKI, 2002, p. 210).

Um dos grandes méritos de Stanislávski e Nemiróvitch-Dântchenko foi precisamente o de compreender que na nova dramaturgia que se estabelecia, a encenação não deveria estar centrada nos acontecimentos do enredo, sendo necessário, portanto, desenvolver o sentido interno da ação cênica. O foco no universo interior, no "mundo espiritual" das personagens poderia proporcionar também ao espectador uma nova relação com a obra, que deixa de ser apenas uma "distração", ou um "divertimento":

Enquanto a ação externa no palco distrai, diverte ou incita os nervos, a ação interna contagia, abrange a nossa alma e toma conta dela. [...] se enganam aqueles que interpretam nas peças de Tchékhov a própria fábula, deslizando pela superfície e representando as imagens externas dos papéis sem criar as imagens internas e a vida interna. Em Tchékhov é interessante a configuração espiritual das suas criaturas (STANISLÁVSKI, 1989, p. 302303).

Assim, na criação do universo interno das personagens, o subtexto e a atmosfera tornam-se palavras-chave, já que os diálogos não carregam em si toda a ação da obra dramática e por vezes as palavras são incapazes de traduzir as verdadeiras intenções, pensamentos e sentimentos das personagens.

Consequentemente, uma das tendências do diálogo tchekhoviano é sua própria dissolução em monólogos paralelos; o falar adquire características líricas, puramente expressivas, perdendo sua função apelativa, a que contribui muitas vezes, a falta de interesse 
ou atenção do ouvinte em potencial, que por sua vez, também está mergulhado em seu mundo interior.

É precisamente o que acontece no início do segundo ato de $O$ jardim das cerejeiras, quando estão em cena Charlotta, Epikhódov, Duniacha e Iacha, e a falta de conexão entre seus universos é manifesta pela solidão da primeira:

CHARLOTTA (com ar meditativo): Não tenho nem mesmo um registro de nascimento... Nem sei ao certo a minha idade, sempre me parece que ainda sou pequenina [...] Quando meus pais morreram eu fui recolhida por uma senhora alemã que começou a me educar. Está bem. Cresci e tornei-me instrutora. De onde venho - não sei. Quem eram meus pais, talvez nem fossem casados... não sei. (Tira do bolso um pepino e começa a mastigá-lo.) Não sei de nada. (Pausa.) Gostaria tanto de poder ter uma longa conversa com alguém... mas quem seria esse alguém? Não tenho ninguém neste mundo.

EPIKHÓDOV (toca o violão e canta): "O mundo pode desabar sobre mim, nada me importa..." Como é agradável tocar bandolim... (TCHÉKHOV, 2006b, p. 86).

Apesar de estarem presentes mais três personagens, Charlotta não encontra ninguém com quem conversar e os outros parecem não ouvi-la, pois ninguém responde a ela; a próxima fala será de Epikhódov, que apenas canta uma canção triste. Revelam-se consequentemente, estados emocionais debaixo da troca superficial de comunicações; as palavras, ao invés de se tornarem meios de comunhão, passam a isolar ainda mais as personagens. O sutil humor de Tchékhov destaca-se na rubrica, que indica o gesto prosaico de Charlotta, "quebrando" o lirismo das réplicas; lembramo-nos infalivelmente dos vagabundos de Beckett, de cujos bolsos sempre tiram uma cenoura ou rabanete...

Se por vezes Tchékhov tenciona os movimentos decorrentes da dramaturgia estruturada pela relação de causa e efeito, por outras, brinca com os mesmos, em um jogo de montar e desmontar as expectativas do leitor/espectador sem, porém, resolvê-las. O próprio autor comenta em carta as inovações decorrentes de tais procedimentos a respeito de Ivánov:

Termino cada ato como os meus contos: conduzo o ato inteiro de maneira tranquila e mansa, mas no final dou um tapa na cara do espectador. Usei toda a minha energia em alguns trechos realmente fortes e vivos, mas as pontes que ligam esses trechos são insignificantes, frouxas e estereotipadas (apud ANGELIDES, 1995, p. 66-67).

O "tapa na cara do espectador" muitas vezes está no inacabamento, nos finais reticentes das peças ou mesmo nos finais reticentes de cada ato. Situações que se decidiriam 
facilmente em obras melodramáticas e nas quais o suspiro de alívio ou lágrima de compaixão do espectador viria inexoravelmente, na poética dramática tchekhoviana desmancham-se sem se resolverem. O conflito interior das personagens não é traduzido pelo diálogo, que acaba expressando apenas trivialidades. Se no sistema dramático tradicional só o que pode ser reduzido a diálogo tem importância, na dramaturgia tchekhoviana temos o oposto: "o que é capaz de se tornar diálogo não tem existência real, ou pelo menos, não tem peso e importância" (ROSENFELD, 2010, p. 105):

VÁRIA ( $f a z$ como se procurasse algo no meio dos embrulhos): Que estranho... Não encontro em parte alguma...

LOPÁKHIN: Está procurando o quê?

VÁRIA: Fui eu mesma que guardei, e agora não sei onde... (Pausa)

LOPÁKHIN: O que pretende fazer agora, Várvara Mikháilovna?

VÁRIA: Eu? Empreguei-me na casa dos Ragúlin. Serei governanta... ou algo assim...

LOPÁKHIN: Eles moram em Iásnievo, não é?... A setenta verstas daqui, apenas... (Pausa). Bem, assim sendo, tudo terminou nesta casa.

VÁRIA (continua a procurar): Mas onde se meteu?... Talvez esteja na mala grande... Sim, para mim a vida nesta casa terminou...

LOPÁKHIN: E eu irei a Khárkov. Agora mesmo, nesse trem. Negócios... Deixo Epikhódov aqui... eu o contratei...

VÁRIA: É mesmo?

LOPÁKHIN: No ano passado já nevava por esta época, lembra? E agora temos um outono tão ensolarado e bonito. Apenas um pouco fresco... hoje de manhã fez três graus abaixo de zero...

VÁRIA: Não olhei... (Pausa). De qualquer modo, o nosso termômetro está quebrado... (Pausa) (TCHÉKHOV, 2006b, p. 117).

O primeiro e último diálogo entre Vária e Lopákhin acontece em uma das cenas finais de $O$ jardim das cerejeiras. Sabemos, por cenas anteriores, que Vária espera um pedido de casamento, embora tenha dúvidas de que Lopákhin o fará. Em meio aos preparativos para a partida, intuímos que esta é a última chance de uma mudança significativa na vida de Vária. As falas, porém, estão longe de refletir os conflitos interiores da personagem e acabam por sublinhar a distância existente entre a governanta e o próspero comerciante. A fartura de pausas e reticências, instrumentos concretos da tessitura do diálogo, aumenta a tensão entre as personagens e cria para o espectador a expectativa de que "algo está prestes a acontecer", ou mesmo de que "tudo se resolverá". Mas em uma poética que não está fundamentada nos acontecimentos do enredo, mas nas transformações sofridas pelas personagens em suas relações e na própria passagem do tempo, e onde devemos ressaltar, o diálogo não se alimenta do entrechoque de vontades, Tchékhov recusa as soluções fáceis. O desfecho da cena não é pontual. Mas passa-se o tempo, Lopákhin é chamado por uma voz de fora, Vária fica só e a 
vida que estava lá fora invade a cena, a hora da partida é chegada. A tensão, que aqui é gerada pela diferença entre as réplicas trocadas pelas personagens e o subtexto, ou seja, o que realmente pensam, sentem e desejam, é elevada ao máximo, mas o desenlace da cena, por assim dizer, não desata o nó entrevisto pelos espectadores/leitores na mesma.

Para Vladímir Katáiev (2002, p. 272), o subtexto deve revelar a incompatibilidade total entre Vária - moça que conta os copeques para administrar a vida cotidiana da propriedade, que leva suas chaves atadas à cintura, ligada às pequenas coisas da vida, como um pardal - e Lopákhin - homem do mundo, conquistador, que tem os olhos no horizonte, como uma águia. A plateia precisa sentir através do subtexto, do que as personagens não dizem, e da própria relação entre elas, do que é "invisível", que Vária e Lopákhin são completamente diferentes.

Assim, na busca para a construção do "invisível" na cena tchekhoviana, para exprimir o "indizível", recursos que no sistema dramático tradicional poderiam ser apenas acessórios para a criação de suspense, intensificando momentos de clímax - como pausas e silêncios passam a constituir a base do diálogo, assim como a presença dos sons e das repetições de palavras.

A emersão de elementos épicos e líricos

Em busca de um tempo-espaço idílico, as personagens tchekhovianas constantemente rememoram o passado, ou se remetem ao futuro, lançando a ele suas expectativas e desejos. $\mathrm{O}$ contraste com a forma dramática em si, em que o presente é o tempo absoluto, torna-se inevitável. Se o gênero dramático tradicional materializava o tempo como transição dos estados de causa e efeito, o drama tchekhoviano revela a própria plenitude da vida, ainda que sufocada na contradição entre passado, presente e futuro.

Mas como nota Anatol Rosenfeld, o tempo tornado tema "é essencialmente do domínio épico" (ROSENFELD, 2010, p. 85), estranho, portanto, ao gênero dramático rigoroso. Da mesma maneira, é a forma épica aquela que tem mais condições de descrever processos, transformações e desenvolvimentos, não necessitando centrar o enredo em conflitos, crises, tensões, como observa Patrice Pavis (2008, p. 68).

Já em 1901 em carta a Tchékhov, Nemiróvitch-Dântchenko percebia a semelhança entre a dramaturgia do autor e a objetividade característica do gênero épico: 
O enredo vai se desenrolando como nos trabalhos épicos, sem essas surpresas que eram essenciais para os dramaturgos mais velhos - a vida como é vivida no meio de brigas simples, verdadeiras. O aniversário, as festas, um incêndio, as despedidas, os fogões, os abajures, um piano, as tortas, a bebedeira, a noite, as criadas domésticas, as arrumadeiras, as camareiras, o inverno, a primavera, o verão, etc., etc. (apud TAKEDA, 2003, p. 170 , grifo do autor).

As modificações estabelecidas por Tchékhov em sua poética dramática podem, portanto, ser caracterizadas pela inserção de elementos épicos na cena dramática ou, como definiu o filósofo e teórico literário russo Mikhail Bakhtin, pela própria "romantização" do gênero dramático (BAKHTIN, 1993, p. 399).

Esta foi, inclusive, uma das críticas recebidas por Tchékhov. O dramaturgo conta em carta que $O$ Silvano $^{45}$ (1889) havia sido considerada por um jornal de Petersburgo como "uma excelente novela dramatizada" (apud ANGELIDES, 1995, p. 158), imprópria, consequentemente, para os palcos. O estranhamento causado pelas inovações da poética dramática de Tchékhov sempre suscitou críticas ao dramaturgo, que lançava as bases para um novo teatro.

Obviamente a presença de elementos épicos na cena dramática não se deu apenas com os autores do "drama novo", mas é notada desde a tragédia grega, como no uso de prólogos, epílogos e nos próprios comentários da ação realizados pelo coro. As consequências que a inserção de elementos épicos e também líricos provocou no drama tchekhoviano, no entanto, foi uma alteração de paradigma dentro do próprio drama - ação e conflito deixam de ser a base da estrutura dramática, os acontecimentos do enredo abandonam o primeiro plano, ocupado pelo subtexto, a vida interior das personagens e as relações entre elas e pela passagem do próprio Tempo.

Para Bakhtin, os acontecimentos do enredo deixam de revelar o homem por inteiro, porque "o homem deixou de coincidir consigo mesmo" (BAKHTIN, 1993, p. 424), ou seja, há uma inadequação das personagens aos seus destinos ou situações. Na poética dramática de Tchékhov podemos notar que "sempre resta um excedente de humanidade não realizado, sempre fica a necessidade de um futuro [...]" (BAKHTIN, 1993, p. 426). As virtudes irrealizadas, as exigências não satisfeitas, a habilidade em se construir planos perfeitos para o futuro e a inabilidade absoluta em pô-los em prática são constantes nas personagens tchekhovianas. O contato com o presente inacabado e incerto é angustiante e o refúgio

\footnotetext{
${ }^{45}$ Comédia em quatro atos, censurada pelas autoridades imperiais, estreou em dezembro de $1889 \mathrm{em}$ Moscou, não sendo bem recebida nem pela crítica nem pelo público. Muitas das personagens e das situações presentes em $O$ Silvano serão rearranjadas por Tchékhov em $O$ tio Vânia.
} 
encontra-se nas memórias do passado ou remete-se ao futuro. No tempo presente nada realmente importante acontece, o que origina o contraste imediato com o tempo do "agora" da cena representada.

Ao rememorarem o passado, as personagens tchekhovianas também estão enfraquecendo a situação verdadeiramente dialógica, básica para o sistema dramático tradicional, que pressupõe uma alta comunhão entre os interlocutores. Uma vez que "a memória encerra o indivíduo na sua própria subjetividade" (ROSENFELD, 2010, p. 88), as personagens se isolam e o diálogo tchekhoviano deixa de ser dialógico, para tornar-se lírico. A comunicação, a troca entre as personagens, deixa de ser prioridade nas relações, pois o fundamental, muitas vezes, é a expressão subjetiva, monológica.

As réplicas, portanto, ao invés de colidirem, correm paralelas e tecem o mundo particular de cada uma das personagens, criando uma multiplicidade de universos; mas tal pluralidade também vai de encontro às regras do sistema dramático tradicional, que admite apenas um e não vários sistemas de referência (BAKHTIN, 2010, p. 17). Para que as réplicas sejam autenticamente dramáticas, o mundo a ser representado deve ser uno, monolítico.

Assim, a poética dramática tchekhoviana não somente assume traços épicos, mas também traços líricos. Por trás da aparente banalidade de cada frase, o subtexto faz com que as palavras abandonem o "cinza" da significação gasta e cotidiana para ganharem novas dimensões. A cena em seu conjunto surge como um poema e as réplicas, em conexão direta com os sons, ruídos, pausas e silêncios presentes nas rubricas, tornam-se musicais.

Foi precisamente esta, a chave com a qual Meyerhold ${ }^{46}$ (1874-1940) abordou as obras dramáticas de Tchékhov. Em carta ao autor, o ator e diretor comenta sobre $O$ jardim das cerejeiras: "Sua peça é abstrata, como uma sinfonia de Tchaikóvski. É pelo ouvido que o encenador deve compreendê-la logo" (apud TAKEDA, 2003, p. 288).

Ao pensarmos a dramaturgia tchekhoviana como música, talvez mais facilmente compreenderemos a pluralidade dos temas em cena, como se cada personagem fosse o instrumento de uma orquestra, cada qual com seu timbre único, realizando diferentes partituras, que Tchékhov elabora com inúmeros detalhes. Temas correm paralelos, ora se entrecruzam, ora se encontram. Os problemas de comunicação entre as personagens são desta

\footnotetext{
${ }^{46}$ Vsevolod Emilovitch Meyerhold foi ator e um dos mais importantes diretores e teóricos teatrais do século XX. Integrou o Teatro de Arte de Moscou (1898-1902), interpretando, dentre outras personagens, o jovem autor Tréplev na encenação de $A$ Gaivota em 1898. Dirigiu o Estúdio de Teatro desta instituição por um ano (1905) a convite de Stanislávski. Em seu trabalho como diretor experimentou diversas formas artísticas e desenvolveu um extenso estudo sobre o movimento e o gesto do ator, conhecido como biomecânica. Foi executado pela ditadura stalinista sob acusação de trotskismo e formalismo. Seu nome esteve banido até 1955, quando foi reabilitado pela corte suprema da ex-URSS.
} 
maneira, consequência desses desencontros, isolamentos, ou por vezes, da própria "incompatibilidade" destes instrumentos.

As palavras, que deixam muitas vezes de expressar os verdadeiros pensamentos e emoções das personagens, também deixam de gerar a ação dramática. O drama tchekhoviano, portanto, passa a necessitar da encenação para realizar-se plenamente. Tchékhov, poeta do não-dramático, do lugar comum, necessita do mundo cênico concreto, dos sons, pausas e silêncios, cuja importância torna-se a mesma das réplicas.

Ao alterar o paradigma do drama - ao invés do drama na vida, Tchékhov criou o próprio drama $d a$ vida, o autor construía o alicerce para um novo teatro, percepção que Meyerhold teve ainda naquela época:

O senhor é incomparável na grandeza de sua arte. Diante das peças dos autores estrangeiros, sua originalidade coloca o senhor à parte. $\mathrm{O}$ drama ocidental terá que aprender a partir do senhor (apud TAKEDA, 2003, p. 289). 


\section{O "INVISÍVEL" E O "INDIZÍVEL" NA CENA TCHEKHOVIANA}

Quem nos dera o caminho feito de um lugar donde ninguém parte para um lugar para onde ninguém vai.

Fernando Pessoa ${ }^{47}$

Dizer que a cena tchekhoviana apresenta-se como um poema significa não somente realçar a musicalidade das palavras de Tchékhov, que se orquestram com as pausas, silêncios e sons rubricados; mas também implica salientar uma íntima e profunda conexão deste tecido sonoro com todos os elementos visuais propostos por Tchékhov. A poesia surge da concretude da própria cena - o que vemos e o que ouvimos se articulam na dramaturgia tchekhoviana para que se possa falar do "indizível", expressar o "invisível".

São estes dois aspectos articulados às particularidades do diálogo tchekhoviano que gostaríamos de tratar no presente capítulo.

\section{Objetos e espaços}

No início dos anos 1960, o dramaturgo Eugène Ionesco (1909-1994), considerado um dos fundadores do teatro europeu de vanguarda, observava que "tudo é linguagem no teatro: as palavras, os gestos, os objetos, a própria ação porque tudo serve para exprimir, para significar" (IONESCO, 1991, p. 197). Se a concisão era fundamento ao qual Tchékhov se atinha ao escrever seus contos, chegando mesmo a afirmar que esta era "irmã do talento" (apud ANGELIDES, 1995, p. 136), no teatro também é um princípio norteador e não somente no que diz respeito às réplicas das personagens, mas também em relação aos elementos plásticos e sonoros propostos. Estes criam mundos, estabelecem atmosferas, interferem diretamente nas ações das personagens. Nada está disposto à toa, tudo tem valor de informação. Avesso a qualquer tipo de excesso, um dos motivos de desentendimento com Stanislávski, Tchékhov notou, não sem humor:

\footnotetext{
${ }^{47} 1986$, p. 388.
} 
É irresponsabilidade dos autores levar ao palco mensageiros, curiosos, policiais. Para que forçar o pobre ator a vestir seu figurino, maquiar-se, se dali a poucos instantes o final é um desagradável e rústico bastidor (apud SENELICK, 1981, p. lviii).

Desta maneira, o espaço, os cenários, figurinos e objetos de cena indicados nas rubricas adquirem uma importância e força que se evidenciam em toda a poética dramática tchekhoviana. Se os diálogos não levam à ação e nem revelam as verdadeiras intenções das personagens, as obras passam a necessitar da encenação para se realizar plenamente. Os elementos visuais adquirem então uma significação que vai além de sua materialidade, atuando diretamente no jogo da cena, em relação estreita com as personagens, como notou o autor russo Leonid Andrêiev ${ }^{48}$ (1871-1919):

no palco Tchékhov deve ser representado não somente por seres humanos, mas por taças, cadeiras, grilos, casacos militares e anéis de noivado... Tudo surge não como itens da realidade ou sons e falas da vida real, mas como os pensamentos e sensações das personagens disseminados pelo espaço (apud SENELICK, 1981, p. 240-241).

Em As três irmãs, as doze batidas do relógio logo na cena inicial fazem com que Olga rememore o passado, um ano atrás quando o pai morrera, ao mesmo tempo em que despertam a consciência das mudanças ocorridas até o presente e o anseio por novas transformações no futuro (ainda que estas sejam um regresso ao passado idealizado). O tempo instala-se "concretamente" através do relógio, materializado no próprio jogo entre a ação dramática e o objeto/sons da cena. Ainda no primeiro ato, o metódico Kulíguin adverte que o relógio está precisamente sete minutos atrasado, em meio a réplicas que se referem a outros assuntos. A meticulosidade do professor, a vida "emperrada" por um sem fim de regras inúteis, é sugerida por Tchékhov através de uma breve comentário da personagem.

Ao fim do terceiro ato, quando as expectativas de retorno a Moscou mostram-se ilusórias, justamente pela própria passagem do tempo - intervalo em que nada acontecera como as irmãs queriam - Tchebutíkin deixa cair um relógio de porcelana, que pertencera à falecida mãe. O relógio, portanto, adquire a força de uma personagem, alcançando um sentido simbólico, poético. O tempo que implacavelmente não volta atrás, tempo de ilusões que se esgotara, despedaça-se materialmente junto com o desejo das irmãs de regressarem a Moscou,

\footnotetext{
${ }^{48}$ Leonid Nikoláievitch Andrêiev, prosador, dramaturgo e jornalista russo, publicou contos, romances, novelas, dramas e comédias.
} 
junto com o amor de Macha por Verchínin, o casamento frustrado de Andrei e a juventude de Irina. Sobrepõe-se o tempo presente eternizado do exílio, limbo de onde não se escapa.

No segundo ato de $O$ tio Vânia, a atmosfera sufocante, de uma madrugada que não passa, é realçada pelas constantes perguntas de Serebriakov sobre as horas; Ástrov ao entrar em cena faz a mesma indagação, após ser desperto não pela tempestade incapaz de aliviar a angústia do tio Vânia e a gota do professor, mas por uma "bela chuvinha".

Na última peça de Tchékhov é justamente a pergunta sobre as horas que abre a cena:

LOPÁKHIN: Bem, graças a Deus, o trem finalmente chegou. Que horas são?

DUNIACHA: Logo serão duas. (Apaga a vela) Já está amanhecendo.

LOPÁKHIN: Quanto atrasou o trem, afinal? Umas duas horas pelo menos. [...] (TCHÉKHOV, 2006b, p. 69).

Ao se prepararem para a partida definitiva no quarto ato, as personagens de $O$ jardim das cerejeiras, retomam a preocupação com as horas, invocando o início da obra, deixando a sensação de "contagem regressiva": "Dentro de dez minutos não estaremos mais aqui"; "Ainda nos restam cinco minutos"; "É hora de partir".

As perguntas constantes sobre o tempo presente indicam o descompasso que as personagens enfrentam, já que vivem muito mais no plano do passado através das memórias, ou no plano do futuro através de expectativas. O presente incerto, que ora se dilata em longas noites chuvosas, ora se comprime em partidas inevitáveis, parece "escorregar" das personagens, que nunca o vivem plenamente.

Papel semelhante ao relógio desempenham as chaves presentes em $O$ jardim das cerejeiras e As três irmãs. Na primeira peça, ao saber que Lopákhin havia comprado a propriedade, Vária propositadamente as joga no chão, contribuindo para a tensão já estabelecida em cena; ainda na mesma obra, Trofimov diz a Ánia que se liberte delas, que deixe o passado e caminhe para o futuro. Na segunda peça, Andrei pede às irmãs a chave do armário que ele havia perdido - como se não pertencesse mais àquele universo, pede através das chaves um reencontro. Irina diz ainda que seu coração é como um piano caro, cuja chave há muito se perdera.

Em uma dramaturgia em que as personagens perdem seus lares, tornando-se seres de raízes arrancadas, as chaves adquirem uma dimensão muito mais profunda, simbólica. Mas além da perda da casa, perdem-se também as próprias chaves. O passado idílico, portanto, está para sempre "trancado" pelas mudanças que se instauram no presente e que definem o 
futuro. A impossibilidade do retorno é sugerida poeticamente e este só pode existir nos planos da memória, do sonho, que assumem grande destaque no sistema dramático tchekhoviano ${ }^{49}$.

Os telegramas que chegam do amante de Paris também têm função dramática precisa em $O$ jardim das cerejeiras. Raniévskaia no primeiro ato, assim que os recebe rasga-os, dizendo que Paris é algo "definitivamente encerrado". Momentos depois no segundo ato, depois de narrar a história de seu passado, tira um telegrama do bolso para em seguida rasgálo novamente. $\mathrm{O}$ diretor Adolf Shapiro, nos ensaios desta cena com atores brasileiros, ressalta que mais do que um simples gesto, a rubrica indica um movimento interno da personagem, sugere uma alteração na relação com o amante e com o espaço do "lá fora" (Paris), pois Raniévskaia, ao contrário de seu gesto no primeiro ato, havia guardado o telegrama. No terceiro ato, em diálogo com Trofimov, a rubrica indica que Raniévskaia tira um lenço do bolso e que um novo telegrama cai no chão. Este se torna foco do diálogo, em que se intensificam os desentendimentos entre as duas personagens.

Tchékhov, nesta cena, torna óbvia a impossibilidade de intersecção entre duas visões de mundo completamente diversas; em poucas palavras, temos frente a frente uma mulher apaixonada (cujo próprio nome, em russo, significa amor), que se deixa levar por seus sentimentos e emoções, e um jovem estudante rebelde.

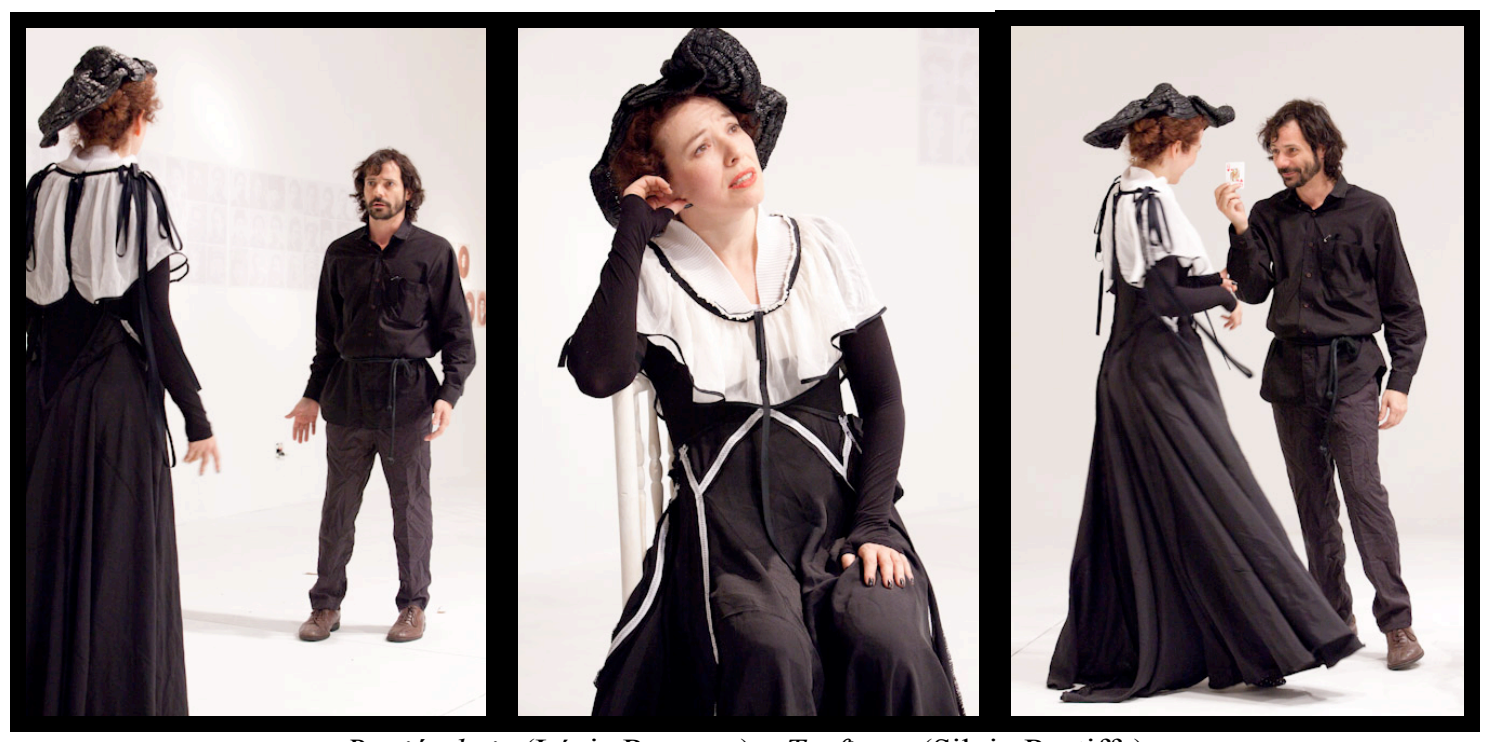

Raniévskaia (Lúcia Romano) e Trofimov (Silvio Restiffe)

em Tchékhov ${ }^{4}$ - uma experiência cênica, dir. Adolf Shapiro. Fotos: Cacá Bernardes.

\footnotetext{
${ }^{49}$ Sobre os objetos na poética dramática tchekhoviana, seria de interesse notar que também o samovar dado a Irina por Tchebutíkin no primeiro ato de As três irmãs materializa o próprio desentendimento entre eles. As irmãs repudiam o "presente tão caro", com o qual Tchebutíkin esperava agradá-las. Em verdade, na época em que Tchékhov escrevera a obra, o samovar era um objeto presente na casa de pequenos burgueses, alheio, portanto, ao universo nobre das irmãs. Assim, pouco a pouco e desde o primeiro ato, o mundo da província invade concretamente a "casa-ilha" em que se refugiam as irmãs Prózorov.
} 
A aflição imensa de Raniévskaia divide-se entre o leilão que se passa na cidade e a decisão de voltar ou não a Paris, impressa na cena através do subtexto. Este é por vezes revelado na fala, abrindo e fechando um tema, como mostram as réplicas sublinhadas:

TROFIMOV: [...] Nós estamos acima do amor!

LIUBOV ANDRÉIEVNA: E eu, devo confessar-lhe, sempre estive muito abaixo dele, minha alminha! (Um forte nervosismo toma conta dela.) Queria saber ao menos se venderam ou não a propriedade. Essa desgraça me parece tão inverossímil que não sei o que pensar; estou desorientada. Seria capaz de gritar... de fazer alguma bobagem... Pétia, salve-me, diga alguma coisa... fale comigo... qualquer coisa.

TROFIMOV: Que diferença faz se a propriedade for leiloada hoje ou amanhã? Pois há muito tempo esse assunto está encerrado. Não é mais possível voltar atrás; o caminho se fechou. Acalme-se, querida senhora... Não devemos nos iludir... Ao menos uma vez na vida encare a verdade de frente!

LIUBOV ANDRÉIEVNA: Que verdade? Talvez o senhor possa ver o que é verdade e o que não é, mas quanto a mim é como se eu simplesmente tivesse perdido a visão; não vejo nada. [...] (TCHÉKHOV, 2006b, p. 102, grifo nosso).

Raniévskaia, que tem as emoções a flor da pele, implora para que Trofimov diga-lhe algo, que a compreenda. Mas para o estudante, que quer verdadeiramente ajudá-la, compreendê-la significa mostrar-lhe o fim de suas ilusões, tudo o que Raniévskaia não quer.

O desentendimento entre ambos, portanto, cresce na mesma proporção em que o estudante torna-se mais empenhado em ajudá-la:

TROFIMOV: Bem sabe que me compadeço da senhora de todo coração...

LIUBOV ANDRÉIEVNA: Sim, mas isso devia ser dito de uma outra maneira, totalmente diferente! (Tira o lenço; do bolso um telegrama cai no chão) Estou tão triste hoje... o senhor nem pode imaginar. E aqui, essa música... [...] É tão engraçado o seu rosto assim sem barba...

TROFIMOV (pega no chão o telegrama): Não pretendo ser um Adônis...

LIUBOV ANDRÉIEVNA : Telegrama de Paris... todos os dias recebo um. Recebi ontem, hoje, todos os dias... Aquele homem mau está doente de novo, as coisas vão mal para ele. De novo pede perdão, suplica que eu volte para ele, e na verdade, eu devia mesmo voltar a Paris e ficar com ele durante algum tempo. O senhor está me olhando tão severamente, Pétia... mas o que se pode fazer, querido? O que devo fazer? O que devo fazer? Aquele homem está doente, está sozinho e infeliz... Quem toma conta dele?... Quem cuida dele para que não volte a fazer bobagens? Quem lhe administra os remédios na hora certa? E por que negá-lo? Amo aquele homem, é verdade, amo-o, amo-o. Esta pedra presa ao meu pescoço é que me puxa para baixo, para dentro do redemoinho... Mas eu quero bem a esta pedra e não consigo viver sem ela... (Aperta a mão de Trofimov). Não pense mal de mim, Pétia... não diga nada... nada.

TROFIMOV (entre lágrimas): Mas, meu Deus... perdoe-me pela sinceridade... esse homem a despojou de todos os seus bens! 
LIUBOV ANDRÉIEVNA: Não, não, não... não fale assim; o senhor não deve dizer essas coisas (Tampa os ouvidos) (TCHÉKHOV, 2006b, p. 103).

No início da cena Raniévskaia implora para que Trofimov diga-lhe algo, ao fim, no entanto, há uma inversão completa, pois ela recusa-se a ouvir. O telegrama caído no chão desperta o tema que havia sido rapidamente mencionado no início do diálogo. Quando Trofimov entrega-o a Raniévskaia, em réplica que pode ser entendida como referência direta ao amante de Paris ("Não pretendo ser um Adônis..."), o subtexto toma o primeiro plano e Raniévskaia expressa todas as questões que até então tinham sido sufocadas. A incompreensão entre eles traduz-se na proporção quase absurda que toma o diálogo - embora falem da mesma pessoa, Raniévskaia refere-se a um coitado e Trofimov a um canalha. Ao querer ajudá-la o estudante a fere e recebe as palavras mais ofensivas em resposta.

Toda a tensão construída, todavia, desfaz-se com um número que bem poderia pertencer a uma das peças curtas cômicas de Tchékhov - Trofimov sai de cena indignado e cai da escada. Os diferentes entendimentos de mundo geram uma pluralidade de pontos de vista e não antagonistas: a seguir Raniévskaia e o estudante perdoam-se e dançam.

Tchékhov apresenta nesta cena, uma situação que se repete em todas as peças analisadas. Coloca lado a lado, em diálogo, personagens que não podem se compreender, pela disparidade entre seus valores, crenças, opiniões e mesmo sentimentos. Entre Raniévskaia e Trofimov não pode haver compreensão, embora o desejem, pois as realidades de ambos correm paralelas, sem que haja entre elas pontos de contato.

Em A gaivota o diálogo entre Macha, uma jovem infeliz, "de luto pela vida" e Arkádina, a grande atriz da província, mostra a diferença entre suas realidades, como se habitassem mundos completamente distintos:

ARKÁDINA: Vamos ficar lado a lado. A senhorita tem vinte e dois anos e eu tenho quase o dobro. Evguêni Sierguêievitch, qual de nós duas parece mais jovem?

DORN: A senhora, é claro.

ARKÁDINA: Viu? E por quê? Porque eu trabalho, eu sinto, vivo atarefada, enquanto a senhorita fica o tempo todo parada, no mesmo lugar, não vive... E eu tenho uma regra: não dirigir meu olhar para o futuro. Nunca penso na velhice, nem na morte. De que adianta, se não há como evitar?

MACHA: Pois tenho a sensação de que nasci há muito, muito tempo; arrasto a minha vida, como uma interminável cauda de vestido... E muitas vezes não sinto a menor vontade de viver [...] (TCHÉKHOV, 2004a, p. 35).

O diálogo, ao invés de impulsionar o conflito entre as personagens, como aconteceria no sistema dramático tradicional, apenas espelha a impossibilidade de contato entre realidades 
distantes. O conflito não está concentrado no antagonismo entre elas, mas pluraliza-se - há o conflito interno de Macha, angustiada e insatisfeita com a vida; e podemos, da mesma forma, vislumbrar o conflito interno de Arkádina, mais escondido, que revela uma mulher em luta com o tempo que passa, que sofre com os ciúmes e tem uma relação difícil com o filho.

Além dos objetos, o espaço proposto por Tchékhov está carregado de significação, determinando a ação dramática e transformando-se de acordo com as mudanças que as próprias personagens sofrem.

As rubricas do primeiro ato de As três irmãs não só indicam o cenário (uma sala na casa dos Prózorov), mas também inserem o espaço épico do "lá fora", onde o sol brilha em um dia ensolarado e alegre. Esta inserção, também uma inovação da poética dramática tchekhoviana, deixa entrever um mundo que está além do microcosmo das personagens, independente, mas que interfere diretamente em suas ações. O espaço do "lá fora" pode compreender um incêndio, uma tempestade, ou milhares de cerejeiras em flor; ou ainda se refere a lugares mais distantes, como o leilão do jardim das cerejeiras na cidade, Moscou, Paris ou mesmo a África. Ainda que não haja intervenções plásticas ou sonoras, estes espaços fazem parte da cena pela relação que as personagens estabelecem com eles.

As transformações por que passava a Rússia em fins do século XIX também são construídas visualmente por Tchékhov em O jardim das cerejeiras. As rubricas do segundo ato indicam bem ao longe uma cidade grande e uma fileira de postes telegráficos. A sensação de que o progresso envolve e ameaça a propriedade é, portanto, sugerida concretamente. Com a venda do jardim e as machadadas sobre as cerejeiras que encerram a peça, pressentimos que este "ao longe" diminui, como se o tempo "de fora" engolisse o tempo do passado no qual a propriedade estava mergulhada.

Este passado, aliás, é múltiplo como indicam as rubricas e objetos presentes em cena. O armário, cujo ranger das portas evoca o próprio tempo, tem cem anos; o velho criado Firs lembra-se dos tempos antigos, quando ainda havia servidão e nos bailes promovidos pela família toda a alta sociedade encontrava-se em peso; o jardim é ancião, ainda mais velho que Firs; o quarto das crianças como ainda é chamado e onde se passam o primeiro e último atos, era o quarto de Raniévskaia e Gáiev, assim como do pequeno Gricha, morto há cinco anos. Os diferentes tempos passados, desta forma, estão impregnados nos objetos e no próprio espaço da ação, referência constante também das réplicas das personagens.

Em sua segunda montagem de $O$ jardim das cerejeiras (1974), que se tornou antológica, o grande diretor Giorgio Strehler deixou ainda mais evidente a materialização do passado através dos objetos e a relação destes com as personagens. O diretor italiano partiu 
exatamente da primeira rubrica (o quarto das crianças como ainda é chamado), principalmente deste "ainda" sugerido por Tchékhov, para construir seu primeiro ato. Strehler deixou em cena cadeiras e mesas pequeninas, do tamanho de crianças, em que Gáiev e Raniévskaia se sentam, exagerando, portanto, o aspecto infantil de suas figuras e alimentando visualmente a tensão entre passado e presente. O quarto torna-se uma espécie de cemitério do tempo que guarda traços de muitas infâncias. A História está presente nos próprios objetos e principalmente no jardim, protagonista que sofre as mudanças provocadas pela passagem do tempo.

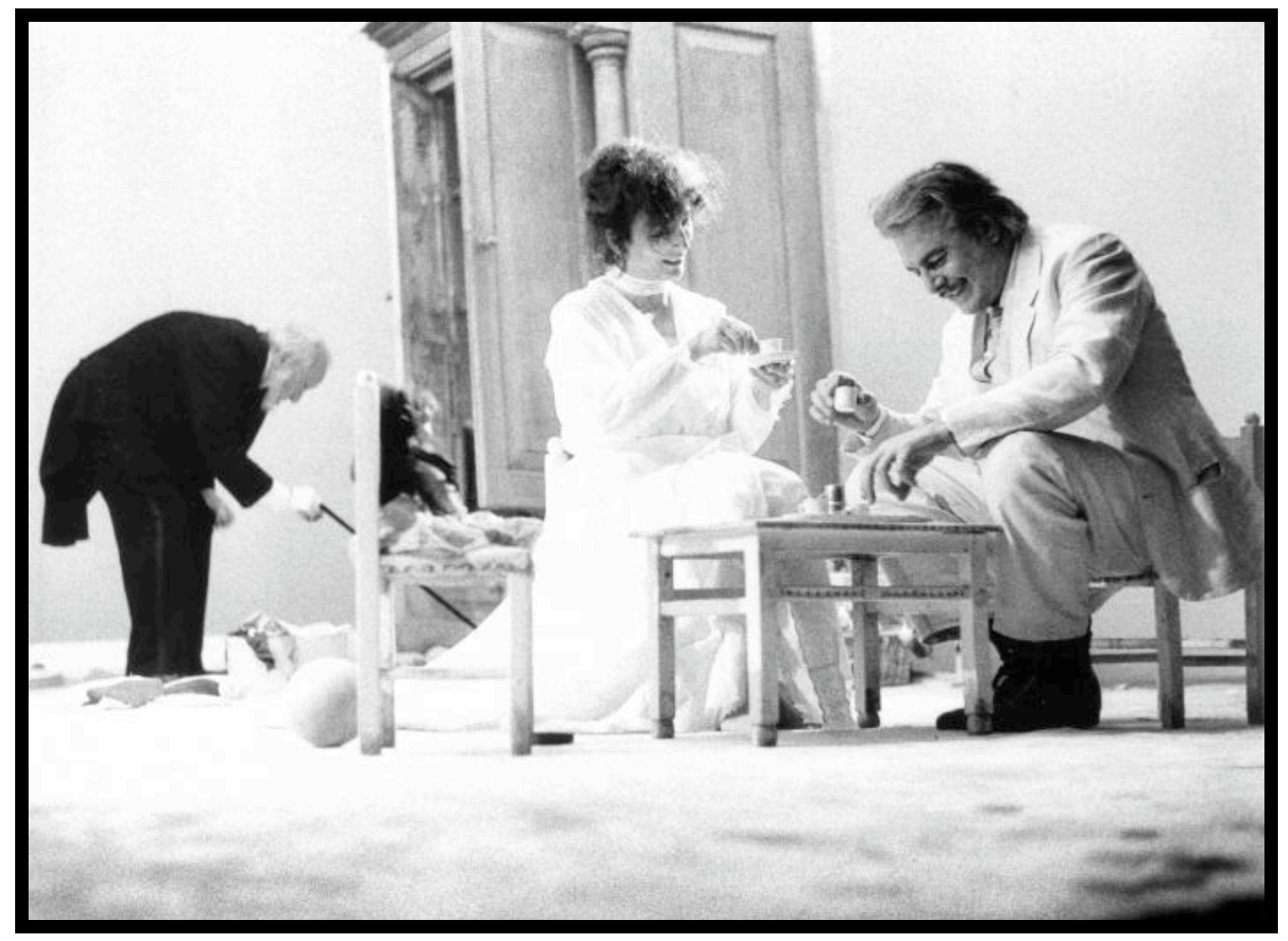

O jardim das cerejeiras (1974) dirigido por Giorgio Strehler.

Firs (Renzo Ricci), Raniévskaia (Valentina Cortese) e Gáiev (Gianni Santuccio). Foto: Ciminaghi Luigi ${ }^{50}$.

Em As três irmãs a dinâmica do espaço acompanha o despedaçar de seus sonhos e ilusões, culminando com a perda da própria casa, tomada por Natacha. O quarto ato se passa fora desta, cenário de todos os atos precedentes; assistimos ao funcionário Ferapont, que havia chegado ali apenas para falar com Andrei, empurrar o carrinho com Bóbik e Protopópov, amante de Natacha, cuja existência nos era dada apenas por sinais (o bolo para

\footnotetext{
${ }^{50}$ Foto disponível em: http://archivio.piccoloteatro.org. Acesso: 19 nov. 2010.
} 
Irina no primeiro ato, os sinos de seu trenó no segundo, os papéis para serem assinados no terceiro), está fisicamente presente na casa, cuidando de Sófotchka.

Objetos que poderiam ser apenas detalhes, na dramaturgia tchekhoviana estão cheios de significação e tomam o centro da ação dramática - um garfo esquecido em um banco e pelo qual Natacha dá novo escândalo com a criada; a crítica a Irina por seu cinto, que nos remetem infalivelmente ao primeiro ato, quando Olga censura Natacha pelo mesmo motivo; os abetos e álamos do jardim que nos planos de Natacha serão substituídos por "flores bonitas e perfumadas".

Em $A$ gaivota e $O$ tio Vânia há um movimento do exterior para o interior, do jardim para o quarto, do dia para a noite. A natureza está fortemente presente, como em toda a obra tchekhoviana e o estado das personagens está frequentemente associado a ela. Esta também é uma das inovações do sistema dramático de Tchékhov e reflete a inserção de elementos épicos e líricos, uma vez que a participação da natureza na ação é traço característico destes dois últimos. A natureza, portanto, dialoga diretamente com as personagens e com a cena, interferindo na ação dramática.

A tempestade que envolve o segundo ato de $O$ tio Vânia parece refletir a desarmonia existente dentro da casa, um grande "labirinto"; as ondas enormes no lago de A gaivota no quarto ato também parecem antecipar as tensões e desentendimentos entre as personagens. $\mathrm{O}$ teatro de Tréplev, que emoldurava a beleza do lago, transforma-se em um esqueleto macabro, de onde Miedviediênko ouve alguém chorar. Nas cerejeiras que preenchem o primeiro ato com sua brancura, Raniévskaia vê a mãe e Trofimov ouve as vozes dos servos que trabalharam na propriedade. Os pássaros deixam a província e o inverno rumo ao sul, ao contrário das irmãs. A lua nasce enquanto se experimenta um novo teatro ou enquanto Trofimov traça planos para o futuro. As cerejeiras que caem sob as machadadas de Lopákhin são a metáfora do fim de uma época. Assim, a natureza também se torna protagonista das obras e como observa Donald Rayfield "pede nossa atenção e compaixão tanto quanto, se não mais, do que as personagens" (RAYFIELD, 1975, p. 228).

O próprio clima instável, em que se teme "que no minuto seguinte comece a nevar", também espelha a agitação interior das personagens. Na primeira cena de $O$ tio Vânia a reação ao clima nos mostra os diferentes universos de cada personagem, o círculo único em que cada uma se encerra e o atrito entre elas mesmo perante um assunto banal: o tio Vânia refere-se ao tempo como quente, sufocante, mas repara que Serebriakov está de galocha, casaco, luvas e como se não bastasse, carrega um guarda-chuva. Para Teléguin o tempo está "encantadoramente belo" e um pouco mais tarde Elena afirma que o tempo está lindo, ao que 
o tio Vânia responde: "Um tempo lindo para a gente se enforcar" (TCHÉKHOV, 1998b, p. 72). No caso do tio Vânia, a contradição absoluta entre "dentro" e "fora" no primeiro ato, indica sua angústia com a situação presente, que ao longo da peça se torna cada vez mais expressa, para explodir no terceiro ato.

Por baixo dos diálogos em que nada parece ser comunicado, escondem-se as angústias e desejos das personagens, conflito interior entre o que se deseja e a própria realidade. Para o tradutor inglês, especialista em literatura russa, Laurence Senelick (1981, p. lviii), o mundo material criado por Tchékhov através dos sons e objetos é precisamente o elemento que une estes diálogos. Assim, os inúmeros objetos presentes no quarto do tio Vânia no último ato não são apenas um amontoado de bric-à-brac (o que contradiria a economia clamada por Tchékhov), mas como nota Donald Rayfield, "criam tensão dramática, enquanto esperamos que a pistola ou a gaiola façam sua parte no drama" (RAYFIELD, 1975, p. 96). O mapa da África pendurado acima da escrivaninha, desnecessário, como manifesta a própria rubrica, sugere um mundo imenso, para sempre fora das perspectivas do tio Vânia, como ressalta o crítico Martin Esslin ${ }^{51}$ (1918-2002), ao mesmo tempo em que pode estar ali apenas por um descuido do protagonista:

a própria incongruência de sua presença ali [o mapa da África] serve para ilustrar o caráter de depressão e ineficiência do tio Vânia. [...] se o pendurou ali, é possível que o mapa o lembrasse permanentemente de um imenso mundo de aventuras para sempre fora de seu alcance, do mesmo modo que talvez estivesse ali simplesmente para tapar uma mancha causada pela umidade (ESSLIN, 1978, p. 57).

Em meio aos preparativos para partir, agradecimentos e despedidas, o mapa desperta a réplica de Ástrov: "Na África deve estar fazendo agora um calor danado" (TCHÉKHOV, 1998 b, p. 122). As palavras do médico, desconectadas de qualquer fala anterior, causam estranhamento, parecem ser ditas à toa, mas têm o poder de invocar outra realidade, quase mágica, pela distância que se impõe entre ela e a situação das personagens: a desolação do tio Vânia e Sonia, a rotina que lentamente se restabelece e um inverno rigoroso que se aproxima. Sem desencadear nenhuma reação expressiva, apenas um seco "sim, é provável", por parte do tio Vânia, a imagem invocada pelo médico leva às personagens e também leitores/ espectadores da obra, para um outro espaço-tempo, distante da ação dramática presente, para em seguida desaparecer como um flash sem deixar vestígios.

\footnotetext{
${ }^{51}$ Crítico teatral, tradutor e professor nascido na Hungria e radicado no Reino Unido. É autor de Teatro do absurdo (1962), obra que cunhou o polêmico termo.
} 
Mas como afirma Tchudakhov, a importância dos objetos não se restringe às réplicas ou às cenas nas quais aparecem e esta é outra grande inovação da poética dramática tchekhoviana:

Os propósitos são mais gerais e de maior alcance. Estes objetos artísticos, dispersos ao longo de toda a obra, criam uma combinada impressão de um mundo integral, selecionado ao acaso, um mundo apresentado acidentalmente, efêmero, individual em um momento temporal específico [...] (CHUDAKHOV, 1983, p. 118).

Este mundo material concreto da cena dialoga com o mundo do "lá fora" e amplia os horizontes da cena tchekhoviana. Em O jardim das cerejeiras uma época está terminando, um universo está se desintegrando, fora e dentro de cena: Duniacha quebra um pires, Raniévskaia derruba todas as suas moedas, Epikhódov quebra um taco de bilhar e uma caixa de chapéus, o termômetro, que registra o frio fora de época no primeiro ato, está quebrado no último. Para Donald Rayfield, o que é aparentemente absurdo adquire uma relevância simbólica: "o calor da África espelha o inferno da vida de Vânia; Balzac em Berdítchev espelha as irmãs na província; a varíola em Tzitzikar simboliza a angústia devastando os Prózorov" (RAYFIELD, 1975, p. 21). Os detalhes presentes no microcosmo das personagens, desta maneira, atingem uma dimensão metafórica, ultrapassando seus primeiros significados e dialogando diretamente com o mundo exterior.

Tchékhov elabora assim, a partir da concretude do mundo cênico, imagens que avançam para o absoluto. Como pretendia Andrei Tarkóvski, a imagem torna-se uma espécie de detector do infinito, "um mundo inteiro refletido como que numa gota d'água" (TARKOVSKI, 2002, p. 130).

\section{Sons e silêncios}

Parte inerente às imagens criadas por Tchékhov é o universo sonoro proposto pelo autor, em um jogo de silêncios, músicas e ruídos, o que Stanislávski concebeu cenicamente como paisagem auditiva ${ }^{52}$. A proporção, no entanto, que tal paisagem deveria assumir dentro

${ }^{52}$ Cf. ROUBINE, 1998, p. 155. 
do espetáculo, foi razão de muitos dos desacordos entre autor e diretor. Em novembro de 1903, Stanislávski escrevia a Tchékhov a respeito da encenação de O jardim das cerejeiras:

Permita-nos, durante uma das pausas, trazer um trem atravessando o palco com pequenas lufadas de fumaça. Isso poderia funcionar esplendidamente. Antes do pôr do sol, a cidade é brevemente visível. Até o final do ato, névoa. Ela surgirá, especialmente densa, do canal na parte baixa do palco. Do mesmo modo, o concerto de sapos e codornas no final do ato (apud TAKEDA, 2003, p. 280).

Ao que Tchékhov responde ironicamente:

Normalmente, a preparação do feno acontece por volta de 20 a 25 de junho, período no qual as codornas e os sapos encerraram, ao que parece, sua música de verão e ficam em silêncio. Pode-se ouvir apenas o papa-figo (apud TAKEDA, 2003, p. 281).

Anos depois em sua biografia Minha vida na arte (1989), Stanislávski reiterava que os sons nas peças de Tchékhov estavam longe de serem acessórios, meros efeitos, mas configuravam elementos fundamentais para que se revelassem as transformações internas de cada personagem. O fato é que o diretor elaborava verdadeiras partituras sonoras, de precisão e riqueza desconhecidas na época. Para ele a inserção destes elementos obedecia às rubricas de Tchékhov:

O lusco-fusco, o nascer e o pôr do sol, a tempestade, a chuva, os primeiros acordes matinais dos pássaros, o tropéu dos cavalos pela ponte e o ruído da carruagem que se afasta, o badalar dos relógios, o cri-cri do grilo e o badalar dos sinos lhe são necessários não para produzir um efeito cênico externo mas para nos revelar a vida do espírito humano.[...] Foi inútil rirem de nós pelos grilos e outros efeitos sonoros e luminosos dos quais lançávamos mão nas peças de Tchékhov, apenas dando vida às inúmeras rubricas do autor (STANISLAVSKI, 1989, p. 304).

Por certo as peças de Tchékhov estão repletas de sons e música, mas não na quantidade que Stanislávski preferia empregar. Polêmicas à parte, um dos méritos do diretor foi o de compreender a função dos sons na poética dramática tchekhoviana - não apenas orquestram a ação, mas agem diretamente na cena, desencadeando ações internas, ou ainda revelando "a ação, o acordo ou a distância, que liga o personagem ao que está em torno dele" (ROUBINE, 1998, p. 155). A guitarra de Teléguin e de Epikhódov, a intimidada orquestra 
judia, os músicos ambulantes, os cachorros, os sons misteriosos que ninguém sabe ao certo o que são, o vento, sons de tiros, fazem parte da ação tanto quanto as réplicas das personagens.

No terceiro ato de $O$ jardim das cerejeiras, enquanto fora de cena ocorre o leilão que decidirá a vida das personagens, Raniévskaia promove um baile: uma flauta, quatro violinos e um contrabaixo tocam durante quase todo o ato. Consequentemente, as réplicas das personagens reduzem-se a fragmentos, emitidos enquanto os diversos pares dançam. $\mathrm{O}$ mundo que se desintegra é levado pelo ritmo da valsa - temos a sensação de uma desarmonia entre o que se passa dentro e fora da casa, entre o interior e exterior das personagens. Para Meyerhold é no meio da dança e da música que entra despercebido o horror:

No Terceiro Ato, tendo ao fundo a "agitação" estúpida - é essa agitação que é preciso saber interpretar - entra, sem que as pessoas percebam, o Horror. "O jardim das cerejeiras foi vendido". Dança-se. "Vendido". Dança-se. E assim até o fim (apud TAKEDA, 2003, p. 288-289).

O horror de que fala Meyerhold parece justamente preencher o hiato entre a realidade fantástica instaurada pelo baile e a aflição interior das personagens. O jogo de bilhar que acontece no salão ao lado e os truques de Charlotta contribuem para que este hiato torne-se cada vez maior, atingindo uma dimensão quase absurda. O bilhar, sugerido por Tchékhov através do barulho das bolas e das tacadas, torna-se metáfora da própria família, em constante jogo com a realidade da vida, com o próprio destino. As mágicas e ventriloquismo de Charlotta também invocam um mundo de ilusão explícito. A governanta chega a parodiar, através de seus números, o acontecimento externo principal do ato - o leilão da propriedade. Fantasia, jogo, dança e música ao se sobreporem às preocupações das personagens quanto aos seus destinos, estão longe de as esconderem, mas revelam novas dimensões das próprias personagens, habitantes de um mundo para sempre fora de seu controle - como acontece nas comédias mais típicas.

A peça de Tchékhov em que se encontram mais fortemente a presença de sons e música, As três irmãs, havia sido escrita especialmente para o TAM. Nela encontramos assobios, sons de violino, um acordeão vindo da rua, o canto de uma ama, o vento soprando na chaminé, sinos, bombeiros, música tocada ao piano, sons de eco e finalmente sons de uma banda militar.

Há ainda no quarto ato a presença de músicos ambulantes (um casal que toca violino e harpa). Em um momento crucial da peça, enquanto Tusenbach disputa o duelo com Solióni, as personagens em cena tornam-se ouvintes de pessoas anônimas. Tchékhov une desta 
maneira, o microcosmo das personagens com um mundo muito mais amplo existente fora de cena, em que vozes que não conhecemos também lutam para sobreviver.

Se em $O$ tio Vânia, em meio à tempestade do segundo ato a necessidade da música é expressa em muitos momentos e sempre negada, em As três irmãs, principalmente no quarto ato, a música está bastante presente, ainda que realce a partida definitiva dos militares, o exílio permanente e o fim das expectativas dos Prózorov.

Dentro da estrutura proposta por Tchékhov, a última cena de As três irmãs ecoa a primeira: ao som do relógio Olga lembra-se no primeiro ato da morte do pai e como um ano depois podiam recordar-se dela "de coração leve"; ao som alegre da banda militar as irmãs se despedem de suas ilusões e a morte do barão é revelada. A música, em diálogo direto com as réplicas das personagens, ajuda-as a consolidarem a crença na própria vida, desta vez com a consciência de que todos seremos esquecidos: "é preciso viver", mesmo que não saibamos por que. Assim, morte e vida configuram um único ciclo, tornam-se afirmação uma da outra e a tragicidade mescla-se à confiança em tempos futuros, quando, talvez, compreenda-se o sentido de ambas.

Por fim, o cantar indiferente do velho Tchebutíkin compõe com a música alegre da banda militar ao fundo uma moldura para as palavras finais das três irmãs que encerram a obra.

A última peça de Tchékhov não termina com música, mas com um som misterioso, que ninguém sabe ao certo o que é, como a corda de um instrumento que se rompe, triste e agonizante. A rubrica ainda indica silêncio e o som surdo de machadadas vindo do jardim. Os sons e o silêncio fazem com que a obra termine em suspensão, alongando-a, como se o tempo presente se eternizasse em interrogações e reticências.

Se no sistema dramático tradicional a função da pausa era criar suspense (a chamada "pausa grávida") ou enfatizar algo para dar tempo à plateia, no drama moderno a pausa muitas vezes existe para focar a impossibilidade do discurso. Junto com elas as réplicas simultâneas, ou sem conexão, os silêncios e as reticências indicam a comunicação rompida, frágil, de personagens isoladas em seus mundos particulares, inábeis para o contato.

Para Tchudakhov, as pausas têm um papel especial na poética dramática de Tchékhov, pois "enfraquecem a densidade dos episódios, uma densidade que é particularmente vital a todo o drama. O ritmo do movimento é atrasado; o fluxo artístico é interrompido; a impressão de uma ausência de ordem é fortalecida" (CHUDAKHOV, 1983, p. 155). No segundo ato de O jardim das cerejeiras, depois de momentos de silêncio e resmungos de Firs, chega pela 
primeira vez de longe um som triste, como que vindo do céu. O diálogo que se segue, cheio de reticências e pausas, alonga o tempo presente da cena, "afrouxando-a":

LIUBOV ANDRÉIEVNA: O que foi isso?

LOPÁKHIN: Não sei o que pode ter sido. Talvez em alguma mina uma caçamba tenha se desprendido. Mas deve ter sido um bocado longe.

GÁIEV: Pode ter sido um pássaro... uma garça ou uma grua...

TROFIMOV: Ou alguma coruja...

LIUBOV ANDRÉIEVNA (com um estremecimento): Parecia vir do outro mundo. (Pausa)

FIRS: Antes da grande desgraça acontecia o mesmo: a coruja gritava e o samovar zumbia, ambos sem parar...

GÁIEV: Antes de qual grande desgraça?

FIRS: Antes de nos alforriarem. (Pausa) (TCHÉKHOV, 2006b, p. 94-95).

A suspensão causada pelas reticências e pausas, ao contrário de gerar expectativas quanto a "o que acontecerá", cria tensão pela interrupção do fluxo que se seguia até então. O silêncio adquire significação, como notou o artista russo Vassíli Kandínski (1866-1944), "fala mais alto do que o barulho, o mutismo adquire uma nítida eloquência" (KANDINSKY, 1996, p. 228). Através das pausas pode-se imaginar os pensamentos e sensações de cada personagem e suas relações com o som misterioso, sem que o autor precise expô-los.

No primeiro ato de $O$ tio Vânia, a discussão entre a personagem-título e a mãe sobre Serebriakov termina com uma pausa, deixando o tema em suspensão - as réplicas não geram ação dramática, não encadeiam nenhum acontecimento, como se esperaria no sistema dramático aristotélico; a próxima réplica de Elena introduz um novo assunto, quebrando a cadeia que se seguia; após nova pausa, o tio Vânia retoma o tema de sua angústia e frustração, ainda que desta vez em resposta à Elena:

MARIA VASSÍLIEVNA: [...] Você esquece que as convicções por si só não passam de letra morta... É preciso agir!

VOINÍTSKII: Agir? Nem todos são capazes de se converter num perpetuum mobile da escrita, como seu Herr Professor.

MARIA VASSÍLIEVNA: O que quer dizer com isso?

SONIA: Vovó! Tio Vânia! Suplico-lhes!

VOINÍTSKII: Está bem, eu me calo. Eu me calo e peço desculpas. (Pausa.)

ELENA ANDRÉIEVNA: O tempo está lindo hoje... Não faz calor... (Pausa.)

VOINÍTSKII: Um tempo lindo para a gente se enforcar... (Teléguin afina o violão, Marina dá voltas em torno da casa, chamando as galinhas.) (TCHÉKHOV, 1998b, p. 76).

As rubricas indicadas por Tchékhov também sugerem um retorno às ações habituais de cada personagem, deixando novamente o tema em suspensão. Externamente o diálogo 
parece quebrado, constantemente rompido, como uma colcha de retalhos cuja costura é precisamente o subtexto das personagens. Os diferentes temas que surgem e se esvaem deixam transparecer a agitação de seus movimentos internos. Muitas vezes a função da pausa é justamente criar as transições entre eles, adquirindo, portanto, uma condição dinâmica, viva, que reforça o subtexto, como nesta réplica de Olga: "[...] se me casasse e passasse o dia em casa seria melhor. (Pausa) Eu amaria o meu marido..." (TCHÉKHOV, 2006b, p. 8).

Enquanto autores ligados ao sistema dramático tradicional escreveriam um longo monólogo para expressar os sentimentos e pensamentos de uma personagem após um grande acontecimento, Tchékhov o substitui pelo silêncio. Quando Lopákhin anuncia a compra do jardim das cerejeiras, a rubrica indica que Raniévskaia, agitada durante todo o ato justamente por causa do leilão, apenas se senta sem dizer nenhuma palavra. O silêncio, carregado de sentido, acaba por expressar mais do que as palavras. De forma semelhante, Macha ao separar-se de Verchínin, ou Irina ao saber da morte de Tusenbach, não declamam longos monólogos: a primeira apenas retoma os versos de Púchkin $^{53}$ (1799-1837), que lhe acompanhavam desde o primeiro ato e Irina somente diz: "eu sabia, eu sabia".

Nos ensaios conduzidos por Adolf Shapiro, o diretor observou que em muitas de suas encenações, constrói toda a cena em função de uma pausa, ou seja, articula todos os ritmos, movimentos internos e ações das personagens para atingir um momento pleno de silêncio. Nas apresentações de Tchékhov ${ }^{4}$ - um estudo cênico, as pausas revelavam um momento de compartilhamento total entre atores e público, como se o silêncio tornasse óbvio o que as palavras das personagens encobriam ou que eram incapazes de revelar.

Em outubro de 2004 quando trabalhava com a cena inicial de As três irmãs no Núcleo Experimental do Teatro Popular do Sesi, como já mencionado, a diretora e pedagoga Isabel Setti pediu aos atores que inserissem em seus textos pequenas, médias e grandes pausas, onde quer que quisessem ou onde percebessem esta possibilidade. Estava claro desde o princípio de que era um exercício, ou seja, uma aventura ao desconhecido. Lembrava-me, no entanto, da irritação de Tchékhov para com as inúmeras e longas pausas das encenações de Stanislávski. Lembrava-me ao mesmo tempo da palavra "aventura".

A cena com a qual trabalhava era o momento em que Olga se lembra do passado, relacionando-se com ele através das batidas do relógio no tempo presente, sonhando com o futuro, ou seja, em que o próprio tempo é palavra-chave. Memória, desejos, inverno, primavera, ação e espera. Aos poucos as pausas chegaram; em vírgulas e pontos e finalmente

\footnotetext{
${ }^{53}$ Alexander Serguêievitch Púchkin, romancista, dramaturgo e poeta russo, considerado fundador da literatura russa moderna. Os versos lembrados pela personagem Macha são do poema Ruslan e Ludmila (1820).
} 
em lugares onde não acreditava que fossem possíveis. O silêncio dizia tanto quanto ou mais que as palavras, adquiria significados próprios, deixava a respiração do tempo presente mais viva, encharcava, travava uma relação direta com a plateia. Por vezes, o próprio silêncio pedia que as palavras fossem emitidas em uma velocidade muito maior, alterando todos os ritmos, quebrando padrões e instaurando verdadeiramente um fluxo de pensamento livre, presente.

Em meu diário sobre o processo de trabalho anotei:

"Neste exercício me preocupei em ouvir. Ouvir o que aquelas palavras queriam dizer. O que o autor - e como é um grande autor - tinha deixado dizer através de sua escrita. Descobri o tamanho deste texto, a humanidade deste texto. Descobri que Olga sou eu, fazendo coisas que não quero, querendo voltar para trás, vivendo de sonhos e se alimentando de dor de cabeça. Descobri que Olga somos todos nós, apegados a um passado bom, atados a ele, desesperançados do presente. Vivendo o passado e o futuro. Mas a cena é o presente. E o tempo é esculpido agora".

Para mim o exercício mostrou a grande potência do silêncio e a re-significação que palavras de sentidos usuais podem adquirir. O silêncio de Tchékhov nunca é vazio, contém vozes de muitos tempos, as muitas vozes de cada personagem e na relação com a plateia, as muitas vozes de cada espectador.

O "invisivel", o "indizivel" e os problemas de comunicação

O sistema dramático tchekhoviano realiza-se, portanto, a partir da concretude da cena - plástica e sonora - do jogo entre os atores, da riqueza dos movimentos internos das personagens e do diálogo com o espectador. Para completar-se, no entanto, o teatro de Tchékhov ainda deve abarcar outros elementos - aquilo que não se expressa nem em palavras, nem em concretudes e que temos chamado de "invisível" e "indizível".

Para o Professor Dr. Vassíli Tolmatchióv, da Universidade de Moscou Lomonóssov, Tchékhov instaura uma poética do vazio, onde os elementos que não existem na realidade concreta em que as personagens vivem tornam-se tão ou mais importantes: no lago com gaivotas, onde se dá a apresentação da peça de Tréplev, clama-se por "leões"; no momento em que há uma plateia, com espectadores mais ou menos atentos, afirma-se que "ninguém escuta" (TOLMATCHIÓV, 2010, p. 8). Não há Moscou, o jardim das cerejeiras será derrubado, o amor não é possível, os pássaros migrantes vão embora, as rotinas se restabelecem. 
Tchékhov, porém, inverte o movimento dramático também neste sentido: o desejo que impulsiona as personagens é mais importante do que sua realização. As personagens tchekhovianas não desistiram, buscam a felicidade, querem dançar, cantar, amar. Nos ensaios realizados na Funarte, Adolf Shapiro insistia justamente neste aspecto: os atores deveriam abordar as personagens não como seres infelizes, mas sim como seres que aspiram até o último momento à felicidade - e como pude comprovar no trabalho prático da cena, são abordagens sutilmente diferentes, mas que levam a resultados completamente diversos.

O conflito das personagens, portanto, encontra-se no fato de que viver e ser feliz não faz parte de suas realidades, como se a vida estivesse contra elas. Mas como conclui Nina em A gaivota, o talento está na persistência; "é preciso viver", apesar de tudo, como dizem as três irmãs, é preciso continuar.

Tchékhov, o poeta do cotidiano, eterniza o transitório, foca o movimento de alma de suas personagens - peripécias não acontecem na trama, mas dentro de cada uma delas. Se o drama não mais se exterioriza em antagonistas, mas se encontra no interior das personagens, Tchékhov cria uma nova linguagem dramática, na qual os diálogos não mais expressam conflitos, mas múltiplas visões de mundo. Os problemas de comunicação entre as personagens são, portanto, um procedimento artístico do autor russo e as palavras adquirem dimensões que vão além de seu puro significado. Se muitas imagens lançam-se para o "invisível", muitas palavras lançam-se para o "indizível".

As palavras muitas vezes parecem não servir às personagens para que possam se fazer entender umas pelas outras. Como se seus sentidos gastos fosse insuficientes para abarcar as múltiplas tonalidades de seus estados de alma. Iúri Lotman nota esta inadequação na própria história da palavra:

Chamados a servir à informação, os signos serviram muitas vezes para desinformar. A "palavra" foi na história da cultura por mais do que uma vez, e simultaneamente, símbolo de sabedoria, de conhecimento e de verdade (veja-se no Evangelho: "No princípio era o Verbo") e sinônimo de mentira, de engano (Hamlet: "Palavras, palavras, palavras, palavras"; Gógol: "O terrível reino das palavras sob a aparência de fatos") (LOTMAN, 1978a, p. 26).

Embora na dramaturgia de Tchékhov a palavra não seja sinônimo de mentira ou engano na mesma proporção fatídica de Hamlet, parece não contemplar as intenções das personagens, como acontece no segundo ato de $O$ tio Vânia, no qual as inúmeras reticências 
"alargam" o diálogo e deixam claro que as palavras não correspondem ao estado interno da personagem:

VOINÍTSKII: Que lágrimas, que nada! Bobagem... Você olhou agora para mim como fazia sua falecida mãe. [...] Minha irmãzinha... minha querida irmãzinha... onde ela estará agora? Se ela soubesse! Ah, se ela soubesse!

SONIA: O quê, tio Vânia? Soubesse o quê?

VOINÍTISKII: É difícil, não é bom... Não é nada... Depois eu... Não é nada, não é nada... Vou indo... (Sai) (TCHÉKHOV, 1998b, p. 90).

A. P. Tchudakhov nota que na obra de Tchékhov há sempre a suposição de certo "além", cuja fronteira é intransponível ao autor, pois ali se encontra um reino em que suas palavras não podem penetrar. Embora possa ser descrito a partir de várias perspectivas, este reino continua inacessível - "as palavras podem atestar sua existência, mas especulações mais profundas são impossíveis" (CHUDAKHOV, 1983, p. 213).

Apresenta-se, portanto, na poética dramática tchekhoviana um paradoxo: desentendimentos e incompreensões afloram entre as personagens para que se possibilite o nascimento das metáforas e da própria poesia. Para a época de Tchékhov e as décadas que se seguiram esta era precisamente a grande inovação - o diálogo, base do gênero dramático, deixa de comunicar. Tal inovação influenciou toda a dramaturgia do século XX considerada de vanguarda, que pôde levá-la a seus extremos.

É justamente este paradoxo que permite ao diálogo deixar de exercer a função de "mola propulsora" de acontecimentos externos, como acontece no sistema dramático tradicional, para tornar-se expressão de indivíduos isolados, onde o que está além das palavras tem mais peso do que o puro significado das mesmas. Se às palavras do autor é impedida a entrada neste território de que fala Tchudakhov, Tchékhov cria novas maneiras de abarcá-lo.

A última cena entre Irina e Tusenbach, por exemplo, é marcada precisamente pela contradição entre as réplicas e o subtexto, tensão que sustenta todo o diálogo. Partindo para o duelo com Solióni, o barão implora para que Irina diga algo, "qualquer coisa", claramente desviando o foco da comunicação do conteúdo da mensagem para o contato:

TUSENBACH: [...] Diga-me algo... (Pausa) Diga-me algo...

IRINA: O que quer que eu the diga?

TUSENBACH: Qualquer coisa.

IRINA: Chega! Chega! (Pausa)

[...]

TUSENBACH: [...] (Sai apressado, para na alameda) Irina!

IRINA: O quê? 
TUSENBACH (não encontra o que dizer): Sabe, hoje eu nem tomei café... Peça para me prepararem um (TCHÉKHOV, 2006b, p. 58-59).

A reação de Irina, que não sabe do duelo, apenas pressente algo de estranho, aviva as inúmeras camadas que se amontoam sob as palavras, incapazes de traduzir as verdadeiras intenções das personagens. As últimas palavras de Tusenbach paradoxalmente atêm-se e ultrapassam seu primeiro significado - uma declaração de amor esconde-se através de um ingênuo pedido.

Tchékhov havia sido criticado em $A$ gaivota também pela falta de teatralidade do suicídio de Tréplev, que se dava nos bastidores sem que a personagem proferisse um monólogo final. Em As três irmãs a morte de Tusenbach também é ocultada dos espectadores e suas últimas palavras certamente estão longe de configurar um fim aos moldes do sistema dramático tradicional, em que a personagem se despediria em um longo monólogo, "resolvendo" todos os conflitos que por ventura ainda necessitassem de uma solução. $\mathrm{Na}$ montagem do diretor russo Piotr Fomenko este é um dos momentos mais memoráveis, aplaudido em cena aberta. A imensa tensão provocada por Tchékhov entre as palavras que as personagens dizem e o que realmente sentem foi explorada pelo diretor e realçada pela interpretação "leve" dos atores. A tragédia que os espectadores pressentem parece tornar-se ainda maior pela alegria que os atores imprimem à cena, avivando as expectativas das personagens quanto ao futuro.

Fomenko realiza com doses certas a combinação, tão cara à dramaturgia de Tchékhov, entre o trágico e o cômico, entre o lírico e o banal. Em sua encenação as palavras tornam-se, como observou Harvey Pitcher a respeito das réplicas tchekhovianas, "como uma máscara que esconde sentimentos muito diferentes" (PITCHER, 1985, p. 115). A montagem de Fomenko estreou em 2004 e continua até hoje no repertório da companhia, tendo recebido inúmeros prêmios em festivais internacionais. 

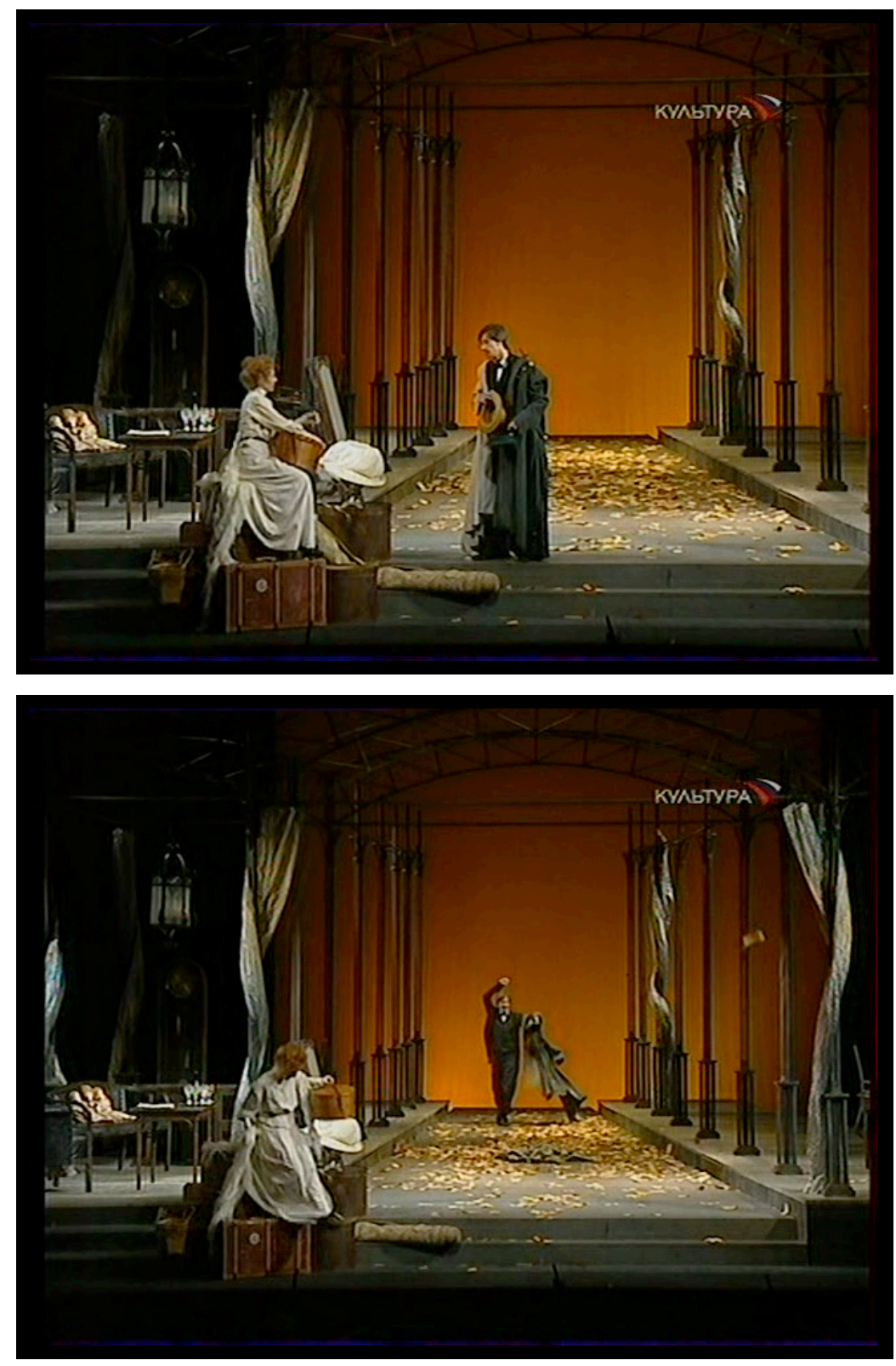

As três irmãs (2004) montagem de Piotr Fomenko. Irina (Ksênia Kutépova) e Tusenbach (Kirill Pirogov) ${ }^{54}$.

$\mathrm{Na}$ despedida entre Macha e Verchínin mais uma vez o foco central dirige-se ao subtexto, que alimenta a tensão estabelecida em cena. Aqui, contudo, não há mais o que dizer, como se a situação estivesse "acima" das palavras, que se demoram junto às inúmeras reticências do diálogo, forma na qual a cena tchekhoviana ainda precisa para se dar:

VERCHÍNIN: Eu vim dizer adeus (Olga se afasta um pouco para não atrapalhar a despedida).

MACHA (olha-o no rosto): Adeus... (Longo beijo.)

OLGA: Já chega...

MACHA (soluça convulsivamente).

\footnotetext{
${ }^{54}$ Imagens retiradas do registro áudio-visual do espetáculo.
} 
VERCHÍNIN: Escreva-me... Não se esqueça de mim... Deixe-me... tenho de ir... Olga Serguêievna, leve-a daqui, eu já... tenho de ir... estou atrasado... (Beija, comovido, as mãos de Olga, abraça Macha mais uma vez e sai rapidamente.) (TCHÉKHOV, 2006b, p. 62).

Há entre Macha e Verchínin uma comunicação plena, que independe das palavras. O amor, como mostra o poeta e ensaísta mexicano Octavio Paz (1914-1998), possibilita o entendimento concreto, a partilha que deve necessariamente fundamentar o processo comunicativo:

Os sentidos nos comunicam com o mundo e, simultaneamente, encerram-nos em nós mesmos: as sensações são subjetivas e indizíveis. O pensamento e a linguagem são pontes, mas, precisamente por isso, não suprem a distância entre nós e a realidade exterior. Com esta ressalva, podemos dizer que a poesia, a festa e o amor são formas de comunicação concreta, quero dizer, de comunhão (PAZ, 1994, p. 181).

Não podemos deixar de observar a semelhança com uma passagem de Anna Kariênina (1877), em que Tolstói (1828-1910) também relata o amor como facilitador da comunicação, que se torna, na relação entre Kitty e Liévin, comunhão, dispensando o uso de palavras:

Ela adivinhou e expressou com perfeição o pensamento que Liévin havia formulado de modo confuso. Liévin sorriu, radiante: assombrou-o muito a transição da discussão emaranhada e palavrosa entre seu irmão e Piestov para essa forma de comunicação lacônica e clara, quase sem palavras, das ideias mais complexas (TOLSTÓI, 2005, p. 393).

O entendimento total com Verchínin em uma comunicação que pode dispensar o uso das palavras contrasta radicalmente com a relação estabelecida entre Macha e seu marido. Professor de latim, uma língua morta, sempre preocupado com detalhes inúteis, Kulíguin recheia suas falas de uma retórica vazia. Seus discursos abordam da mesma forma os mais diferentes assuntos e fazem do amor algo tão habitual quanto o recolher dos tapetes e cortinas no verão:

KULÍGUIN: Hoje, senhores, é domingo, dia de descanso. Descansemos pois, nós também, e vamos nos divertir, cada um conforme sua idade e posição social. No verão os tapetes devem ser retirados e guardados até o inverno... Com inseticida ou naftalina. Os romanos eram um povo saudável, pois sabiam tanto trabalhar quanto descansar, não era à toa que propalavam: Mens sana in corpore sano. Sua vida decorria dentro de determinadas formas. Nosso diretor diz: o mais importante na vida é a sua forma... o que perde a sua forma acaba... E assim ocorre também no nosso dia-a-dia. (Abraça Macha e ri) Macha me ama. A minha mulher me ama. E as cortinas 
devem ser retiradas, junto com os tapetes... Hoje estou muito alegre, de excelente humor. [...] (TCHÉKHOV, 2006b, p. 19).

A meticulosidade de Kulíguin, o modo idêntico com que trata tanto assuntos importantes como banalidades, dão comicidade aos seus discursos e à própria personagem. Tchékhov, contudo, não transforma seu professor em uma imagem caricata, pois ao mesmo tempo vemos um homem verdadeiramente apaixonado, que leva uma vida sem sonhos nem poesia, o que gera em Macha angústia e tédio. Instaura-se um mecanismo de comunicação paradoxal que cresce gradualmente ao longo da peça: quanto mais lúcida Macha se torna sobre sua condição - o exílio na província, o amor impossível com Verchínin - mais Kulíguin tenta convencê-la cegamente de seu amor e felicidade:

KULÍGUIN: Já vou... Minha esposa é uma ótima mulher, é uma mulher magnífica. Minha querida, eu a amo, só a você...

MACHA (irritada): Amo, amas, amat, amamus, amatis, amant.

KULÍGUIN (ri): Sim, é uma mulher deveras extraordinária. Vivemos juntos há sete anos, e para mim é como se tivéssemos casado ontem, palavra de honra. Sim, é uma mulher extraordinária, mesmo. Estou feliz... feliz, feliz, feliz.

MACHA: E eu estou até aqui. Até aqui, até aqui, até aqui! [...] (TCHÉKHOV, 2006b, p. 47).

Macha e as irmãs, assim como Elena Andréievna (de $O$ tio Vânia), são personagens femininas extremamente fortes, preparadas para uma vida muito melhor do que aquela que de fato levam; sufocam em uma realidade que achata suas qualidades, fazendo com que a lacuna entre a vida que se leva e a vida que se deseja ou para a qual foram preparadas, torne-se gigantesca.

A partida de Verchínin sentencia o que Macha mais teme e o que Kulíguin mais deseja: o restabelecimento de suas rotinas, o regresso à "vidinha de antigamente".

Constelações paralelas

O sistema dramático inovador de Tchékhov permite que por baixo de palavras e comentários triviais, escondam-se personagens complexas, cheias de insatisfações e angústias, como acontece com Tchebutíkin, o velho médico de As três irmãs. Na maior parte do tempo, 
o doutor lê notícias de jornal sem importância, completamente desconexas de réplicas anteriores, muitas vezes absolutamente nonsense:

IRINA: A paciência vai dar certo, já estou vendo. Iremos para Moscou! FEDÓTIK: Não, não vai dar certo, veja, o oito está sobre o dois de espadas. (Ri) Portanto, não irão para Moscou.

TCHEBUTÍKIN (lê o jornal): Em Tzitzikar declarou-se uma epidemia de varíola (TCHÉKHOV, 2006b, p. 32).

Temos, portanto, a impressão constante de que os diálogos "patinam" pela desconexão entre as réplicas, consequência da ausência de comunicação entre as personagens:

SOLIÓNI (entra na sala na companhia de Tchebutikin): Com uma mão levanto só um pud e meio, mas com as duas chego a levantar cinco ou até seis puds. Sendo assim, concluo que dois homens têm não apenas o dobro de força de um, mas pelo menos o triplo.

TCHEBUTÍKIN (andando, lê um jornal): Contra queda de cabelos... dissolver dois gramas de naftalina em meia garrafa de álcool... friccionar todas as noites... (anota em sua caderneta). Tomaremos nota disso. (A Solióni) Preste atenção. Empurramos a rolhinha no frasco. Um tubinho de vidro a atravessa. Depois, pegamos uma pitada do mais simples, do mais comuns dos alumes... (TCHÉKHOV, 2006b, p. 9).

O diálogo é traçado poeticamente, não para fazer com que o drama "avance", mas para possibilitar a expressão do que não pode se revelar através das palavras. Como ressalta Harvey Pitcher "é a habilidade em sugerir através de poucas linhas a complexa vida interior das personagens que representa a fina arte dos diálogos tchekhovianos" (PITCHER, 1985, p. 22).

A independência de cada réplica também denota a falta de escuta entre as personagens, exemplificada no chamamento irônico de Tchebutíkin para Solióni, "preste atenção", que configura uma breve tentativa de contato entre dois mundos completamente diferentes.

O diálogo tchekhoviano tende muitas vezes, portanto, a sua própria dissolução em monólogos paralelos. $\mathrm{O}$ falar perde sua função apelativa, a que contribui muitas vezes a falta de interesse ou atenção do ouvinte em potencial:

VERCHÍNIN: De qualquer modo, é pena que a juventude se tenha ido...

MACHA: Gógol diz em algum lugar: 'É aborrecido viver neste mundo, senhores!'

TUSENBACH: E eu digo: é difícil discutir com os senhores! Com os diabos... 
TCHEBUTÍKIN (lendo um jornal): Balzac casou-se em Berdítchev... (Irina cantarola em voz baixa.) Anotarei em minha agenda. (Anotando.) Balzac casou-se em Berdítchev. (Volta a ler o jornal.)

IRINA (jogando paciência, pensativa): Balzac casou-se em Berdítchev (TCHÉKHOV, 2006b, p. 31).

Nesta cena Macha, Verchínin e Tusenbach discutem sobre a própria vida, seu sentido e o futuro. Tchebutíkin, inesperadamente, lê em voz alta a notícia sobre Balzac, supérflua, com aspecto de "resposta de palavra cruzada". O doutor ainda repete a informação ao escrevêla em seu caderno. E Irina também repete as mesmas palavras, que acentuadas pela rubrica de Tchékhov, mostram que a personagem está completamente imersa em outra realidade. Os assuntos e sentimentos misturam-se, alinhavados apenas pela lógica do subtexto.

Os diálogos nos quais perguntas permanecem sem respostas, como palavras ao vento, são constantes em As três irmãs:

TUSENBACH: O senhor diz que a vida na terra, ao cabo de muitos anos, será assombrosamente bonita. Certo. Mas, para participarmos dela desde já, mesmo à distância, devemos nos preparar e temos de trabalhar...

VERCHÍNIN (levantando-se): Sim. Olhe só, quantas flores têm aqui! (Esquadrinha a sala) E que casa magnífica! Eu os invejo. Passei a vida toda em apartamentos apertados. Duas cadeiras, um divã e um fogão sempre soltando fumaça. Eram essas flores que faltavam na minha vida. (Esfrega as mãos) Mas enfim, para que falar nisso?

TUSENBACH: Sim, é preciso trabalhar. O senhor de certo pensará: um alemão sentimental [...] (TCHÉKHOV, 2006b, p. 17-18).

As réplicas tanto de Verchínin quanto de Tusenbach não respondem exatamente ao que foi proferido imediatamente antes, enfraquecendo a troca de mensagens entre eles, ao mesmo tempo em que assumem uma função lírica, expressiva. A subjetividade das falas substitui o dialogismo de argumentações antagônicas objetivas, deixando que o fluxo da própria vida conduza a cena.

As réplicas desconexas, embora mais presentes em As três irmãs e $O$ jardim das cerejeiras, estão presentes em todas as quatro peças analisadas. Em A gaivota:

CHAMRÁIEV: Lembro que, certa vez, no teatro de ópera em Moscou, o famoso Silva cantou o dó mais grave. Nessa ocasião, como que de propósito, estava sentado na galeria um dos baixos do coro da nossa arquidiocese, e de repente, os senhores podem calcular o nosso espanto, ouvimos uma voz lá na galeria: "Bravo, Silva!". Uma oitava inteira abaixo... Assim: (com voz grave) "Bravo, Silva!". O teatro como que congelou. (Pausa)

DORN: Passou um anjo por aqui.

NINA: Está na minha hora. Adeus (TCHÉKHOV, 2004a, p. 26-27). 
Em O tio Vânia:

TELÉGUIN: Eu também não me encontro em perfeitas condições de saúde, excelência. Sinto-me indisposto há dois dias. A cabeça...

SEREBRIAKOV: Onde estão os outros? Não gosto desta casa. Parece um labirinto [...] (TCHÉKHOV, 1998b, p. 105).

Em Ojardim das cerejeiras:

LOPÁKHIN: Pois é, o tempo passa.

GÁIEV: O que disse?

LOPÁKHIN: Digo apenas que o tempo, infelizmente, voa.

GÁIEV: Que cheiro é este?

ÁNIA: Vou me deitar. Boa noite, querida mãezinha (TCHÉKHOV, 2006b, p. 75).

O paralelismo das réplicas é uma das consequências da amplitude de universos presentes na poética dramática tchekhoviana, paradoxalmente em diálogo, compartilhando o mesmo tempo-espaço da cena. Esta se apresenta como um grande mosaico, em que cada personagem representa uma constelação única, incompreensível para as demais. O diálogo, ao invés de troca e/ou comunhão, reflete consequentemente a distância e a impossibilidade do contato entre as personagens. Para a pesquisadora holandesa Jenny Stelleman, as personagens tchekhovianas assumem que "o outro modela o mundo ou a realidade exatamente da mesma maneira que elas, em outras palavras, que há apenas uma realidade" (STELLEMAN, 1992, p. 29). Desta forma, os problemas de comunicação causados pela falta de experiências similares que isola cada personagem em seu mundo individual, são agravados pela premissa de que o outro "modela o mundo do mesmo modo que eu"; tal proposição possibilita aparente entendimento, como se as realidades se tocassem breve e harmoniosamente, assim como as pedras de um caleidoscópio, para em seguida afastarem-se definitivamente.

Em A gaivota a relação da jovem aspirante à carreira de atriz, Nina, e o escritor consagrado, Trigórin, é pautada exatamente pelo modo ilusório com que cada um modela a realidade do outro: Nina deseja alcançar a vida de celebridade de Trigórin, é atraída pela realidade dos artistas bem sucedidos "como uma gaivota é atraída para o lago":

NINA: Em troca da felicidade de ser uma escritora ou uma atriz, eu suportaria o desprezo dos meus conhecidos, a penúria, as desilusões, eu moraria num sótão, só comeria pão de centeio, suportaria a insatisfação comigo mesma, sofreria com a consciência das minhas imperfeições, mas em compensação eu exigiria para mim a glória... a glória autêntica, 
estrondosa... (Esconde o rosto nas mãos) Minha cabeça está rodando... Ah! (TCHÉKHOV, 2004a, p. 50).

Para Trigórin, no entanto, a fama é inverossímil, desagradável:

TRIGÓRIN: [...] "O que o senhor anda escrevendo? Com que nos brindará a seguir?" Sempre a mesma coisa, sempre a mesma coisa, e fico com a impressão de que essa atenção de meus conhecidos, os elogios, a admiração, tudo isso é uma mentira, tenho a sensação de que estão me enganando, como fazem com uma pessoa doente [...] (TCHÉKHOV, 2004a, p. 47-48).

O escritor famoso preza a natureza e as coisas simples: "Pescar uma acerina ou uma perca, isto sim é o auge da felicidade!" (TCHÉKHOV, 2004a, p. 89), para o espanto de Nina, que se choca com a atitude do artista:

NINA: [...] E como também é estranho que um escritor célebre, adorado pelo público, sobre quem todos os jornais escrevem, cujo retrato é vendido em toda parte, um escritor que já foi traduzido em outras línguas, passe o dia todo pescando no lago e fique contente por ter apanhado duas carpas [...] (TCHÉKHOV, 2004a, p. 43).

Desta maneira, a comunicação entre Nina e Trigórin é frágil, como se o contato entre seus mundos fosse brevemente possibilitado pela intersecção de seus desejos, paradoxalmente opostos: Nina modela o mundo de Trigórin pela beleza da fama e do estrelato, Trigórin interessa-se pela pureza, inocência e ingenuidade de Nina. Para Vassíli Tolmatchióv, Trigórin é um "mitificador", pois cria uma ilusão fatídica: "a gaivota ou Nina como atriz - e envia tal ilusão, assunto ressuscitado do seu caderno de anotações para a cidade" (TOLMACHIÓV, 2010, p. 9). O grande choque, portanto, ocorre no encontro entre a realidade "verdadeira" de cada personagem e a realidade "projetada"/"mitificada" pelo outro.

No filme O tio Vânia (1971), o diretor Andrei Konchalóvski concretiza plasticamente a pluralidade de universos das personagens tchekhovianas e seu consequente isolamento, retratando-as mergulhadas em suas preocupações e interesses individuais. Os focos de seus olhares poucas vezes se encontram, como se as distâncias de seus pensamentos não o permitissem: 


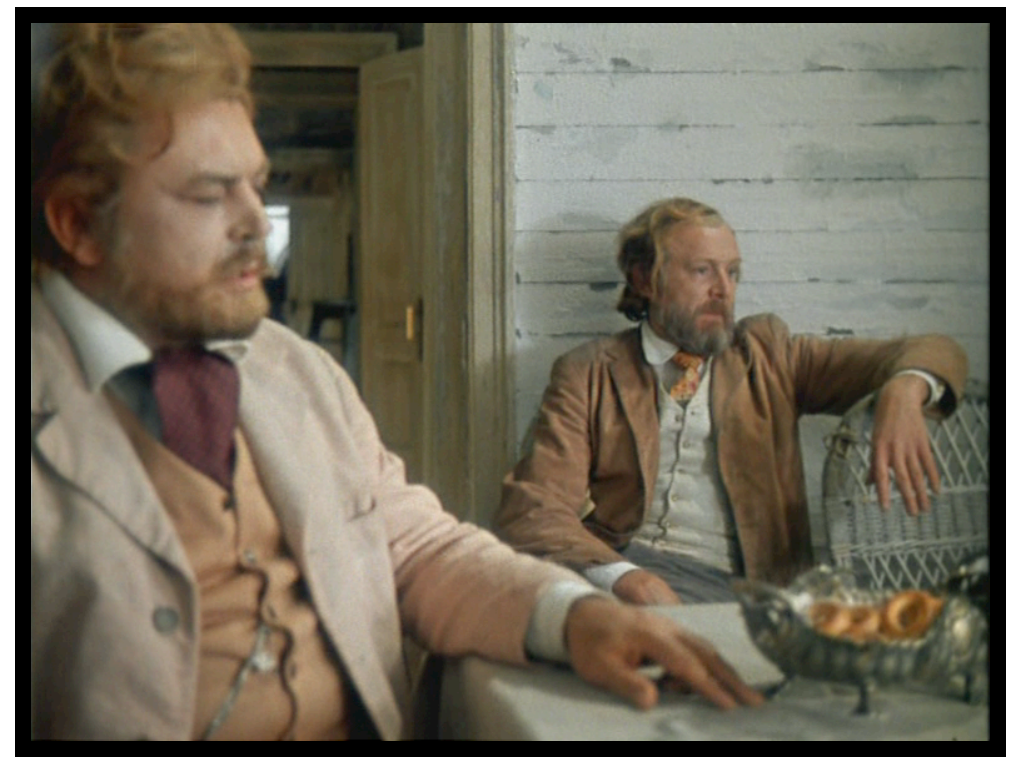

KONCHALÓVSKI, Andrei. O tio Vânia, 1971. 00:07:09

Dr. Ástrov (Serguêi Bondarchuk), Voinitskii (Innokénti Smoktunósvski)

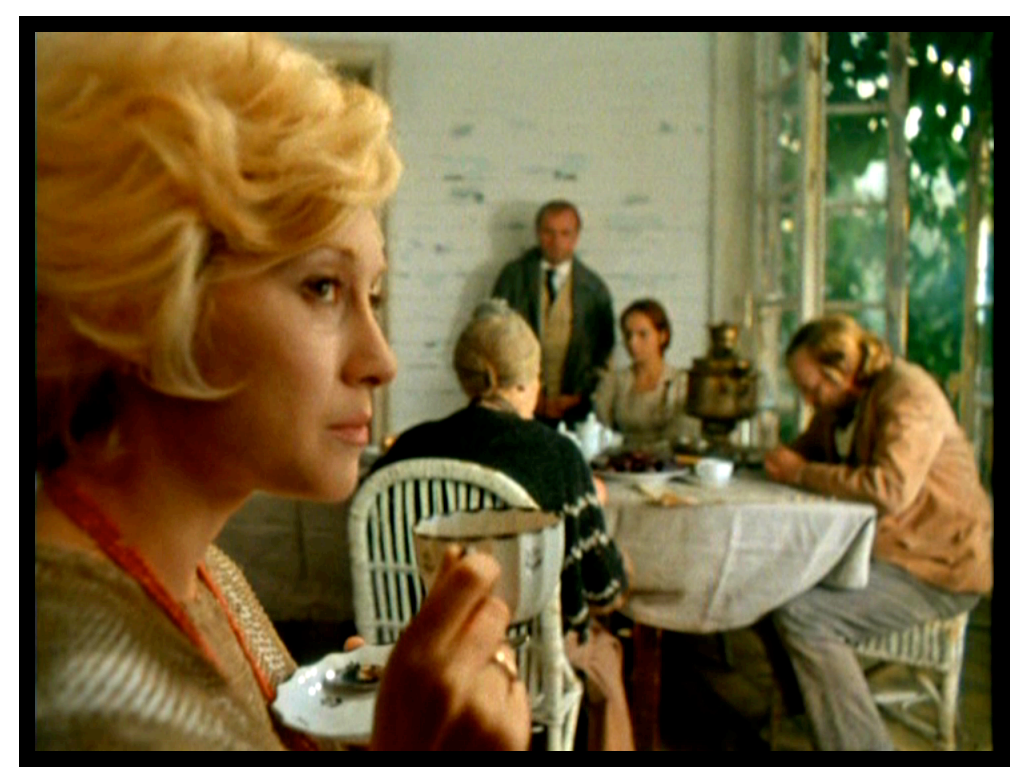

KONCHALÓVSKI, Andrei. O tio Vânia, 1971. 00:14:11

Em primeiro plano Elena Andréievna (Irina Mirochnitchenko).

O retraimento do tio Vânia, que se sente incompreendido e esmagado por angústias e frustrações, traduz-se nas imagens de Konchalóvski e na interpretação do grande ator Innokénti Smoktunósvski ${ }^{55}$ (1925-1994). Os diferentes planos criados pelo diretor realçam as contradições internas do tio Vânia, espelhadas na contraposição entre interior/exterior da casa. A imensidão do mundo que se vislumbra das janelas parece ecoar a profundeza da solidão do tio Vânia:

\footnotetext{
${ }^{55}$ Ator de teatro e cinema interpretou papéis marcantes, como o Príncipe Míchkin em $O$ idiota, adaptação teatral da novela de Dostoiévski dirigida por Tovstonógov em 1957 e Hamlet, no filme de Grigóri Kózintsev em 1964.
} 


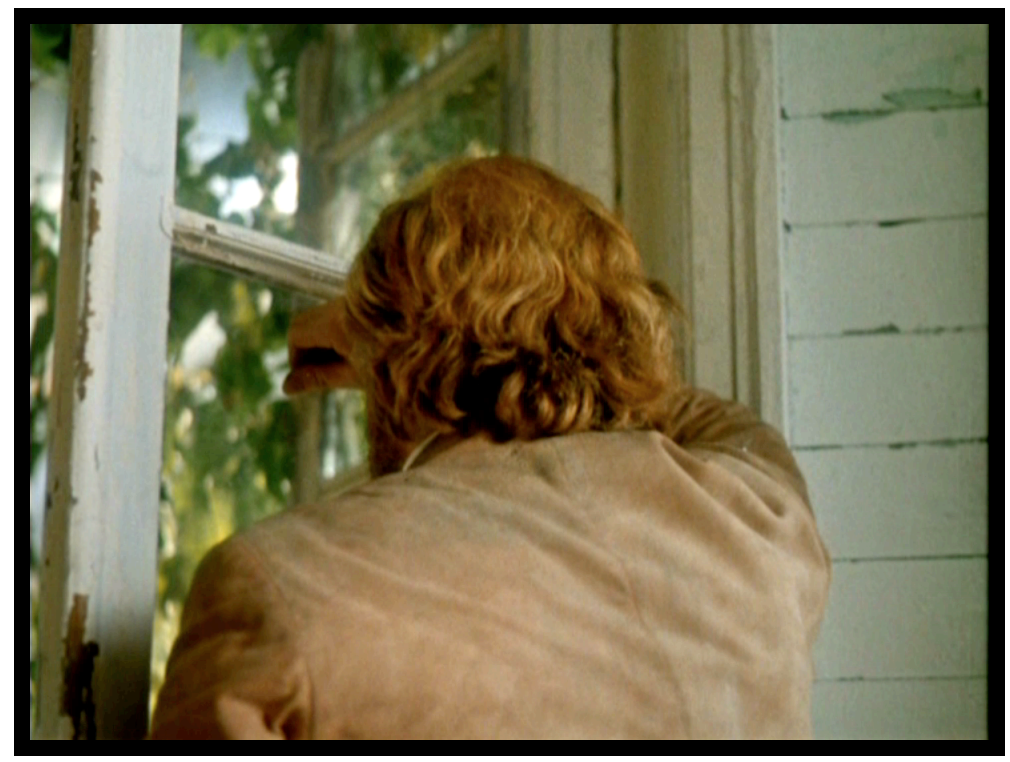

KONCHALÓVSKI, Andrei. O tio Vânia, 1971. 00:14:23

Voinitskii (Innokénti Smoktunósvski)

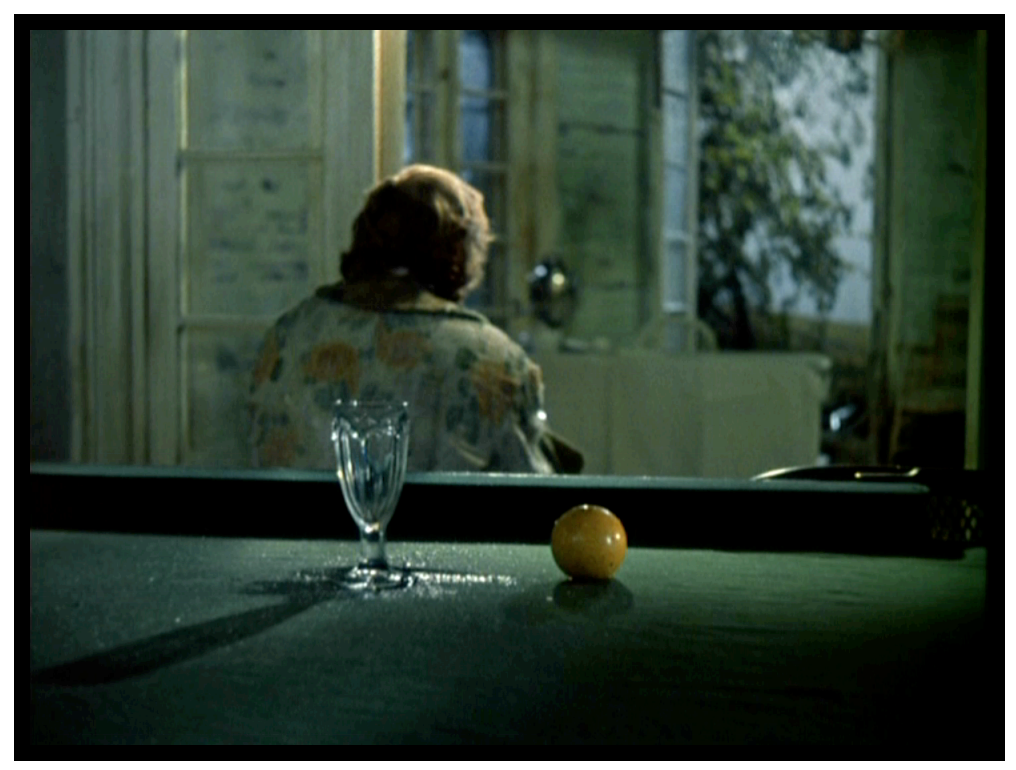

KONCHALÓVSKI, Andrei. O tio Vânia, 1971. 00:36:03

Voinitskii (Innokénti Smoktunósvski)

A imagem do segundo fotograma contrapõe claramente dois eixos, metáfora da própria contradição interna da personagem. No eixo horizontal, temos o mundo exterior a casa, onde a natureza está fortemente presente; sua amplitude é sugerida pela presença do próprio horizonte ao longe, que supomos ser o foco do olhar do tio Vânia. No eixo vertical, temos a dimensão interna da casa, ambiente sufocante, de onde o tio Vânia não consegue escapar; as gotas que caem dentro da taça em ritmo constante sublinham este eixo.

A complicada rede de tensões de $O$ tio Vânia estreita-se ainda mais no segundo ato, em uma atmosfera de esgotamento e impaciência. Todos rodeiam o Professor Serebriakov, 
este doente caprichoso e exigente, em uma madrugada de tempestade em que ninguém dorme. Desencontros e incompreensões são constantes e preparam a culminação de angústias do terceiro ato, como a taça retratada por Konchalóvski que pouco a pouco começa a transbordar.

A impossibilidade do contato entre realidades diferentes explicita-se na cena entre Sonia e Ástrov, ainda no segundo ato. Apaixonada pelo médico, Sonia acha que entende sua angústia e o ama ainda mais por acreditar que pode salvá-lo. Mas para o doutor Sonia é apenas uma menina, o oposto de Elena Andréievna, que poderia lhe "virar a cabeça num único dia":

ÁSTROV: [...] Como ia dizendo: meu tempo passou, agora é tarde... Envelheci, trabalhei demais, tornei-me superficial, meus sentimentos se embotaram, e certamente não conseguiria estabelecer uma relação íntima com ninguém. Não amo mais... e nem vou me apaixonar por mais ninguém. A única coisa que me empolga é a beleza. A ela não sou indiferente. Acho que, se Elena Andréievna quisesse, conseguiria virar minha cabeça num único dia... Mas isso não é amor, não é uma relação íntima... (TCHÉKHOV, 1998b, p. 92-93).

Em monólogo posterior, Sonia declara como lhe é terrível não ser bonita (ao que a rubrica indica a entrada da bela Elena). O modo como Ástrov reage a sua pergunta, que Sonia faz com imensa dificuldade, como se há muito tempo tomasse coragem para formulá-la, indica de imediato a impossibilidade de uma relação entre eles:

SONIA: [...] Diga-me Mikhail Lvóvitch... Se eu tivesse uma amiga ou uma irmã mais nova e se o senhor viesse a saber que ela... suponhamos, o ama, qual seria sua reação?

ÁSTROV (encolhe os ombros): Não sei. Provavelmente nenhuma. Faria com que ela compreendesse que não posso me apaixonar por ela... Mas não é isso que me ocupa a cabeça agora... De qualquer forma, já é mais que hora de partir. Adeus, queridinha, senão esta conversa não termina nem ao raiar do dia. (Dá-lhe um aperto de mão) [...] (TCHÉKHOV, 1998b, p. 93).

A rubrica "dá-lhe um aperto de mão", que finaliza a cena entre ambos, realça a distância entre os desejos e expectativas de Sonia e os interesses de Ástrov. Sonia, contudo, não entende o "ponto final" dado pelo médico e mantém suas esperanças até o último ato, quando a partida de Elena, Serebriakov e do próprio Ástrov sentenciam o restabelecimento de uma vida sem surpresas.

Tchékhov entalha uma moldura para este regresso, usando a repetição dos termos "foram-se"/"foi-se", proferidos por diferentes personagens imediatamente antes de voltarem 
para suas ações habituais, como uma "orquestração de respostas a um destino comum" (WILLIAMS, 2002, p. 188):

\author{
(Ouve-se o tilintar de sininhos). \\ ÁSTROV: Foram-se. O professor decerto está contente! Agora nada mais o \\ fará voltar aqui. \\ MARINA (entra): Foram-se. (Senta-se na poltrona e põe-se a tricotar uma \\ meia). \\ SONIA (entra): Foram-se. (Secando os olhos). Que Deus os acompanhe! \\ (Ao tio) Então, tio Vânia, mãos à obra! \\ $[\ldots]$ \\ MARIA VASSÍLIEVNA (entrando lentamente): Foram-se. (Senta-se e \\ mergulha na leitura) (TCHÉKHOV, 1998b, p. 121).
}

A estrutura se repete após a partida de Ástrov:

VOINÍTSKII (escreve): "Dia 2 de fevereiro, 20 libras de óleo... Dia 16 de fevereiro mais 20 libras de óleo... cevada..." (Pausa. Ouvem-se as campainhas dos cavalos).

MARINA: Foi-se (Pausa)

SONIA (retorna e deposita a vela sobre a mesa): Foi-se (TCHÉKHOV, 1998b, p. 122).

Sonia, assim como as três irmãs, vê seus sonhos aniquilados ao fim da peça, quando lhe sobra apenas a crença no trabalho e em um futuro melhor, em que "descansaremos". Da mesma forma, em A gaivota Nina conclui que o verdadeiro talento não está na fama, mas na persistência, na constância, na "capacidade de suportar":

NINA: [...] Agora eu sei, Kóstia, agora eu compreendo que no nosso trabalho, representando no palco ou escrevendo, o que importa não é a glória, não é o esplendor, não é aquilo com que eu tanto sonhava, mas sim a capacidade de suportar. Aprenda a carregar a sua cruz e acredite. Eu acredito e, assim, nem sofro tanto e, quando penso na minha vocação, não sinto medo da Vida (TCHÉKHOV, 2004a, p. 95-96).

Nina, contudo, experimenta consequências drásticas do choque entre o mundo projetado por ela e a realidade, ao passar pelas próprias provações que imaginou. Entre o terceiro e quarto atos (em um intervalo de dois anos), através da narração de Tréplev, fica-se conhecendo sua vida difícil como atriz principiante em Moscou, seu romance com Trigórin, os ciúmes, o nascimento e morte de seu bebê. Essa excelente "coleção de incidentes" (KATAEV, 2002, p. 175), que poderia fazer a felicidade de um autor de melodramas, na peça de Tchékhov, entretanto, é transferida para a imaginação do espectador/leitor. Importa mais 
ao autor as mudanças que se processaram no interior da personagem, já que não vemos os infortúnios de Nina em Moscou, mas contemplamos "concretamente" as consequências das transformações que sofreu quando se reencontra com Tréplev no último ato.

A experiência artística e os desastres pessoais levam-na a uma reflexão e reavaliação de sua vida anterior. Se a peça de Tréplev representada sem cenário, à beira do lago e à luz da lua era "tão sem graça", "difícil de representar", "com pouca ação", ela se torna, dois anos depois, lembrança de uma vida "radiante, afetuosa, alegre, pura". Em meio à confusão de suas últimas réplicas, ao fim do quarto ato, quando mistura citações de Turguêniev ${ }^{56}$ (1818-1883), ideias de Trigórin e confissões do passado e do presente, as palavras escritas por Tréplev são as únicas de que Nina se recorda com clareza. Se antes eram palavras vazias, "só declamação do começo ao fim", as experiências sofridas pela jovem atriz dão agora às palavras do jovem escritor peso e significação, a solidão devastadora da "Alma do Mundo".

Apesar de se tornar um escritor publicado ao fim de A gaivota, Tréplev ao contrário de Nina, ainda sente-se perdido: "Eu não acredito e não sei qual a minha vocação" (TCHÉKHOV, 2004a, p. 96). Seu talento torna-se sua própria perdição, como profetizara Dorn no primeiro ato: "O senhor precisa saber para que escreve, senão ao trilhar esse caminho pitoresco sem ter um objetivo bem definido, vai acabar se perdendo e o seu talento será a sua perdição" (TCHÉKHOV, 2004a, p. 29-30).

Para Harvey Pitcher (1985, p. 64-65) este é precisamente o "objetivo bem definido" de Tchékhov em $A$ gaivota: não basta que um indivíduo seja talentoso - se suas qualidades pessoais não estiverem no mesmo nível de seu talento, este poderá então ser facilmente corrompido.

Se por um lado a experiência artística leva Nina e Tréplev a descobertas e profundas transformações, como se partissem, segundo Vladímir Katáiev (2002, p. 175), de sensações e elucubrações - "parece-me que" - para chegarem ao fim da peça com a verdade da experiência - "verificou-se que", por outro deixa Arkádina e Trigórin sob o signo da estabilidade e da fixidez. Convivem lado a lado em A gaivota o idealismo e o pragmatismo, o "talento sem objetivo" e a regularidade diligente, o anonimato e a fama.

Escritor profissional e experiente, Trigórin desenvolveu técnicas e métodos para realizar sua arte. No segundo ato em seu encontro com Nina tem a oportunidade de falar longamente sobre seu ofício, esclarecendo o tormento e a obsessão em escrever, as insatisfações consigo mesmo e a recepção morna de público e crítica.

\footnotetext{
${ }^{56}$ Ivan Serguêievitch Turguêniev, prosador e dramaturgo russo, autor, dentre outras obras, do romance Pais e filhos (1862) e da peça Mês no campo (1872).
} 
Embora Trigórin não sofra através da arte transformação radical como Nina e Tréplev, Tchékhov faz com que o escritor estabelecido, famoso, também questione sua própria escrita: "[...] Eu nunca agradei a mim mesmo. Não gosto de mim como escritor" (TCHÉKHOV, 2004a, p. 49). A contestação de Trigórin cria dialética na obra e não permite que a personagem torne-se porta-voz do autor. Para A. P. Tchudakhov, o questionamento de Trigórin, escritor experiente, assim como o de Tréplev, escritor principiante, e que representam visões opostas na arte, demonstra que "uma contradição única era insuficiente para Tchékhov. Ambas tese e antítese são questionadas mesmo por seus defensores" (CHUDAKHOV, 1983, p. 193). A exposição de pontos de vista opostos sem que se chegue a uma síntese é aspecto recorrente na poética dramática tchekhoviana e ressalta o caráter interrogativo das obras.

Assim como Trigórin e Arkádina, as outras personagens de A gaivota permanecem mergulhadas nas mesmas aflições e desejos do início da peça. O intervalo de dois anos entre o terceiro e quarto ato sublinha a sensação de continuidade, ou mesmo o agravamento deste estado, chamando a atenção para a passagem do tempo.

Sórin, irmão de Arkádina, que está mais doente, resume sua condição de l’homme qui a voulu, manifesta desde o início da peça:

SÓRIN: [...] eu queria ser escritor, e não fui; queria falar bonito, e falava pessimamente [...]. Queria casar, e não casei; queria muito viver na cidade, e fui acabar minha vida no campo, e assim por diante (TCHÉKHOV, 2004a, p. $80)$.

Arkádina continua sendo a grande diva: "Os estudantes me aclamaram... Três corbelhas, duas coroas e ainda por cima isto aqui... (Tira um broche do peito e o joga sobre a mesa)" ( TCHÉKHOV, 2004a, p. 88).

Macha e o professor Miedviediênko, aparentes exceções, também permanecem imersos nas mesmas aflições que demonstravam já na primeira cena da peça, como em um beco sem saída. Apesar de terem se casado, suas almas permanecem "sem pontos de contato", não há escuta:

MACHA: Você é um estorvo. No início, só queria saber de filosofar e agora só fala do bebê e de ir para casa, do bebê e de ir para casa... não se ouve outra coisa da sua boca.

MIEDVIEDIÊNKO: Vamos para casa, Macha!

MACHA: Vá você sozinho.

MIEDVIEDIÊNKO: O seu pai não vai me emprestar os cavalos.

MACHA: Vai, sim. É só você pedir que ele empresta. 
MIEDVIEDIÊNKO: Por favor, eu imploro. Então, amanhã você virá para casa?

MACHA (aspira rapé): Está bem, amanhã. Mas que coisa enjoada... (TCHÉKHOV, 2004a, p. 76).

Se na tragédia clássica o destino dos heróis era pré-determinado pelos deuses, com quem a possibilidade de luta era inexistente, na poética dramática tchekhoviana o destino das personagens também é determinado por forças que elas são incapazes de superar; como se a fatalidade de seus destinos fosse consequência também de uma série de incomunicações entre elas, isoladas em seus mundos e pontos de vista particulares.

Os desentendimentos para os quais contribuem as ações de cada personagem mergulhada em seu universo particular levam a uma cadeia geral de infortúnios. Vladímir Katáiev destaca que não há intenções vis nas atitudes das personagens, mas apenas distância entre seus propósitos e perspectivas:

As personagens de Tchékhov tornam-se os autores dos infortúnios de outras pessoas "simplesmente" porque estão tentando realizar suas próprias ideias de felicidade, amor, arte, como conduzir as coisas, etc. Ser o autor dos infortúnios de outras pessoas não é a sina de indivíduos particulares que são maus, cruéis e imorais. Cada pessoa está sujeita a isso. Ter uma visão pessoal das coisas, estar preocupado com esta visão e ser incapaz de entender a "verdade" das outras pessoas - isso é o que leva aos infortúnios e às vidas arruinadas em Tchékhov (KATAEV, 2002, p. 178).

A passagem inflexível do Tempo e a recusa de Tchékhov a um final feliz contribuem para a extinção das ilusões. Não entendemos, no entanto, que tais fatores deem às obras característica pessimista como talvez possam sugerir. A este respeito, observa novamente Vladímir Katáiev:

Não é um final infeliz, mas a recusa a um final feliz o desenlace comum a todas as peças de Tchékhov. Em seus finais Tchékhov não estava "matando esperanças", mas sim matando ilusões, chamando a atenção para a genuína complexidade dos problemas da existência humana (KATAEV, 2002, p. 256 , grifo nosso).

Neste sentido, a ação do Tempo torna-se motor das obras, revelando pouco a pouco às personagens a impossibilidade da concretização de seus sonhos e desejos, ou de suas ilusões. Tchékhov materializa a passagem do tempo em cena através de diversos procedimentos: no choque entre as lembranças do passado e expectativas quanto ao futuro e o próprio tempo presente da cena representada; nas estações do ano (que tanto se harmonizam com o estado de 
espírito das personagens); na chegada e partida das personagens; em dinâmicas de memórias e esquecimentos: Trigórin, por exemplo, não se lembra quando, ao fim de A gaivota, Chamráiev lhe dá o pássaro que pedira para ser empalhado; apesar disso, tem "já bem maduro" o "tema para um conto curto", cuja inspiração tivera naquela mesma ocasião, quando se encontrara com Nina e ao seu lado estava a gaivota morta por Tréplev; em As três irmãs Irina já não se lembra de palavras em italiano, Macha começa a se esquecer do rosto da mãe e não se recorda ao fim da obra dos versos que insistentemente lhe surgiam no primeiro ato.

Os finais de Tchékhov, portanto, não determinam um ponto final, mas um recomeço, alongam-se em direção ao eterno. Como em uma espiral infinita, apresentam-nos uma trajetória completa, mas dentro de um percurso que intuímos ser muito maior, o percurso da própria Vida.

Monólogos sobrepostos ou um "diálogo de surdos"

Um outro procedimento de que Tchékhov se utiliza para retratar os problemas de comunicação entre as personagens é um recurso típico da comédia, o "diálogo de surdos". Em seu caderno de anotações, em que deixava pensamentos, temas e ideias para obras futuras, estas "brincadeiras" entre personagens que não se ouvem são frequentes:

Filho: Eu acho que hoje é quinta.

Mãe (sem ter ouvido): O quê?

Filho (nervoso): Quinta! (Mais baixo) Tenho que tomar um banho.

Mãe: O quê?

Filho (nervoso e ofendido): Banho! ${ }^{57}$.

E ainda:

"N ficou pobre." - "O quê? Não ouvi." - "Eu disse que N ficou pobre." - "O que foi que você disse? Não consigo entender. Que N?" - "O N que se casou com Z." - "Bem, e daí?" - "Eu disse que temos que ajudá-lo." - "Hein? Ajudar quem? Por que ajudar? O que você quer dizer?" - E assim por diante $^{58}$.

\footnotetext{
${ }^{57}$ CHEKHOV, A. Note-book of Anton Chekhov. Trad. S. S. Koteliansky e Leonard Woolf. Disponível em: http://www. gutenberg.net/1/2/4/9/12/12494, p. 31-32. Acesso: 10 abr. 2009.

${ }^{58}$ Ibid., p. 58.
} 
Em $O$ jardim das cerejeiras a surdez do velho criado Firs provoca suas intervenções sem sentido:

VÁRIA: Por que você está tão bem-humorado, velho Firs?

FIRS: Às suas ordens!

$[\ldots]$

LIUBOV ANDRÉIEVNA: [...] Muito obrigada, querido Firs, muito... Se soubesse, velho, como me alegro por você estar ainda vivo!

FIRS: Anteontem (TCHÉKHOV, 2006b, p. 75-76).

Diferentemente dos diálogos presentes em seu caderno, ou mesmo das primeiras peças curtas em um ato (que Tchékhov também chamava de "brincadeiras"), marcadas pela comicidade, nas quatro peças analisadas a dimensão cômica nunca vem desacompanhada da dimensão trágica. Ao mesmo tempo em que rimos das réplicas desconexas de Firs, pressentimos seu isolamento e solidão: o velho criado pertence a um mundo que está se desfazendo, a um tempo que já passou. Vladímir Nabókov nota que o humor "tipicamente tchekhoviano" é baseado justamente nesta unidade, já que para Tchékhov "as coisas eram engraçadas e tristes ao mesmo tempo, mas você não veria sua tristeza se não visse sua graça, pois ambas estão interligadas" (NABOKOV, 1981, p. 252). O próprio Tchékhov declarou: "[na vida] tudo está misturado - o profundo e o superficial, o grandioso e o insignificante, o trágico e o cômico" (TCHÉKHOV, 2002a, p. 207).

Vladímir Propp ${ }^{59}$ (1895-1970) (1992) também destaca que o humor de Tchékhov está cercado de cordialidade, é atenuado e inofensivo e provoca um riso "bom", em oposição ao riso de escárnio ou zombaria, causado por defeitos retratados por espessas lentes de aumento $^{60}$.

Assim, os diálogos entre Andrei e o funcionário surdo Ferapont em As três irmãs, em que ambos falam sem se entenderem, deixam claro a solidão de dois mundos diferentes. $\mathrm{O}$ isolamento de Andrei força-o ao silêncio - conversa com Ferapont justamente por saber que ele não pode escutá-lo e o velho funcionário, por sua vez, fica isolado pela impossibilidade de contato. Temos, portanto, a presença de monólogos sobrepostos, mas neste caso dentro de uma estrutura mais aparente de diálogo, com réplicas que se sucedem rapidamente, o que realça a impressão de divergência, uma vez que é "tanto mais forte quando ela simula uma convergência como pano de fundo" (SZONDI, 2001, p. 53):

\footnotetext{
${ }^{59}$ Vladímir Iakoléievitch Propp, folclorista e teórico literário russo, cujas pesquisas sobre os contos maravilhosos e os estudos sobre comicidade adquiriram grande destaque.

${ }^{60}$ Cf. Capítulo 21 (PROPP, 1992, p. 152-161).
} 
ANDREI: [...] Meu Deus, sou secretário do conselho municipal, do conselho onde o chefe é Protopópov. Secretário, e no máximo posso chegar ao cargo de assessor! Ser assessor do conselho local, eu, que todas as noites em meus sonhos era professor da Universidade de Moscou, sábio famoso, orgulho de toda a Rússia.

FERAPONT: Quem?... Ouço mal.

ANDREI: Se não ouvisse mal, irmãozinho, eu não conversaria com você. Afinal de contas, tenho de conversar com alguém. Minha esposa não me entende, às minhas irmãs eu temo, não sei por que razão. Receio que elas riam de mim, que me envergonhem... Não bebo, não frequento tabernas; no entanto, meu querido velho, que alegria me daria estar agora em Moscou, no Testov ou no Grande Moscovita!

FERAPONT: Em Moscou, segundo me contou um mestre de obras, uns comerciantes resolveram comer panquecas e um deles teve morte súbita por ter comido quarenta panquecas. Quarenta ou cinquenta, já não sei ao certo.

ANDREI: Estar em Moscou sentado no salão principal do restaurante. Mesmo não conhecendo ninguém e tampouco ninguém o conhecendo, você não se sente um estranho... E aqui, mesmo sendo conhecido de todos e todos sendo seus conhecidos, você se sente um estranho... um estranho... Estranho e solitário.

FERAPONT: O que disse? (Pausa) E aquele mestre de obras contou também - talvez estivesse mentindo - que em Moscou foi estendida uma grande corda sobre a cidade (TCHÉKHOV, 2006b, p. 26).

Andrei encontra-se ilhado, incapaz de ser compreendido e paradoxalmente também de compreender. Ao contrário do que sonhava, torna-se membro do conselho municipal do qual Protopópov, amante de Natacha, é presidente e acaba hipotecando a casa para pagar dívidas de jogo.

As confissões ao velho funcionário, com quem a comunicação verbal é impossível, não só pela surdez de Ferapont, mas também pela ausência de contextos comuns entre ambos, são o único alívio de Andrei. Apenas Ferapont, precisamente por sua incapacidade em ouvir, serve como interlocutor ao irmão Prózorov. O diálogo adquire uma dimensão quase nonsense, já que Ferapont também fala, mas obviamente sobre outro assunto.

A surdez física de Ferapont na cena que se segue funciona como uma lente de aumento à surdez velada de Natacha, desinteressada e insensível ao que se passa com o marido:

ANDREI: [...] Que diabo você quer?

FERAPONT: O quê? São os papéis; tem de assiná-los.

ANDREI: Estou farto de você.

FERAPONT (entrega-lhe os papéis): O porteiro da Secretaria de Finanças me disse agora mesmo que no inverno em São Petersburgo fez duzentos graus abaixo de zero.

ANDREI: O presente é repugnante, mas apesar disso quando penso no futuro tudo se transforma! Fica tudo tão leve, tão espaçoso; se ao longe 
rompe uma luz, vejo a liberdade, vejo a mim e a meus filhos nos livrarmos do ócio, do $k_{v a s}{ }^{61}$, do ganso e do repolho, da sesta, da abjeta falta do que fazer...

FERAPONT: Ele diz que ficaram congeladas mais de duzentas pessoas. O povo morria de medo... Foi em São Petersburgo ou em Moscou, já não sei mais...

ANDREI (comove-se): Oh, minhas irmãs queridas, minhas irmãs encantadoras... (com lágrimas nos olhos) Macha, minha irmãzinha querida. NATACHA (da janela): Quem está falando tão alto? É você, Andrei? Você vai acordar Sófotchka. Il ne faut pas faire du bruit, la Sophie est dormée déjà. Vous êtes un ours. (Irritada) Se quiser gritar, passe o carrinho para alguém. Ferapont, tome o carrinho do patrão.

FERAPONT: Sim, senhora (pega o carrinho) (TCHÉKHOV, 2006b, p. 60).

A intervenção de Natacha na cena cria uma multiplicidade de vozes e o diálogo acaba por explicitar não só o isolamento e solidão de Andrei, mas dos três interlocutores. Enclausurados em mundos particulares, só os abandonam para pequenas tentativas de contato.

\section{Uma paródia}

Se o paralelismo entre as réplicas é aspecto constante na poética dramática tchekhoviana, no segundo ato de As três irmãs Tchékhov parodia a dramaturgia tradicional, ao fazer com que as réplicas se choquem. $\mathrm{O}$ conflito introduzido, no entanto, não conduz à ação, mas ao contrário, gira em círculos pela banalidade do assunto abordado. Há entre Tchebutíkin e Solióni uma discussão vazia, promovida pelo simples prazer da troca de réplicas argumentativas certeiras, pontuais. Tchékhov repete logo em seguida a mesma estrutura, ao fazer com que Solióni e Andrei discutam sobre quantas universidades há em Moscou. Não se chega obviamente a nenhuma conclusão em nenhum dos casos:

TCHEBUTÍKIN (entra na sala acompanhado de Irina): E fomos tratados à moda caucasiana. Sopa de cebola e assado de tchekhartina, um tipo de carne.

SOLIÓNI: A tcheremcha nunca foi carne, é um vegetal, parecido com a cebola.

TCHEBITIKIN: Querido, a tchekhartina não é cebola, é carne de cordeiro.

SOLIÓNI: E eu lhe digo, que a tcheremcha é cebola.

TCHEBUTÍKIN: E eu lhe digo que a tchekhartina é carne de cordeiro.

SOLIÓNI: E eu lhe digo que a tcheremcha é cebola.

\footnotetext{
${ }^{61}$ Bebida popular russa, fermentada à base de pão de centeio e malte.
} 
TCHEBUTÍKIN: Ora, por que essa discussão! O senhor nunca esteve no Cáucaso e tampouco comeu tchekhartina.

SOLIÓNI: Não comi porque não gosto. A tcheremcha tem o cheiro do alho. [...]

TUSENBACH: [...] Irei para Moscou junto com você, para a universidade, Andriuchka!

SOLIÓNI: Qual? Em Moscou há duas universidades.

ANDREI: Em Moscou há uma universidade.

SOLIÓNI: Pois eu digo que há duas.

ANDREI: Por mim pode haver até três. Para mim tanto faz.

SOLIÓNI: Em Moscou há duas universidades! (Protestos e assobios) A velha e a nova. E se os senhores não prestam atenção, ou não lhes agrada o que eu digo, então posso calar-me e até mudar de sala. (Sai por uma das portas) (TCHÉKHOV, 2006b, p. 34-35).

Desta forma, convivem em As três irmãs, de um lado, as discussões vazias, os discursos banais, como os de Kulíguin com suas citações em latim, a linguagem infantilizada com que Natacha se comunica com as crianças, o refrão sem sentido "tsip, tsip, tsip" repetido por Solióni em ameaça ao barão Tusenbach, as canções de Tchebutíkin e suas falas nonsense; de outro, as réplicas poéticas das irmãs, cheias de sonhos, povoadas pelas imagens de árvores e pássaros - os próprios versos de Púchkin que acompanham Macha durante toda a peça evocam um lugar perfeito, idílico, junto à natureza.

O vazio que se insinua em muitas das réplicas tchekhovianas é radicalizado por diversas obras do século XX, nas quais falar serve mesmo e declaradamente para passar o tempo, sem gerar ação. Na cena abaixo de Fim de partida (1957), uma das primeiras peças de Samuel Beckett, há primeiramente o desacordo entre as personagens, carregado de ironia; em um espaço muito curto as réplicas deixam de colidir para correrem paralelas, resultado do desencontro entre dois universos distintos, mas interdependentes. Hamm, tirano cego e aleijado, condenado à imobilidade de sua cadeira, e Clov, dominado pelas ordens de Hamm e que ironicamente não consegue se sentar, não deixam de ecoar na síntese da cena beckettiana, os desentendimentos presentes no teatro de Tchékhov:

Hamm: A natureza nos esqueceu.

Clov: Não existe mais natureza.

Hamm: Não existe mais! Que exagero!

Clov: Nas redondezas.

Hamm: Mas nós respiramos, mudamos! Perdemos os cabelos, os dentes! A juventude! Os ideais!

Clov: Então ela não nos esqueceu.

Hamm: Mas você disse que não existe mais natureza.

Clov (triste): Nunca ninguém pensou de modo tão tortuoso como nós.

Hamm: A gente faz o que pode.

Clov: Fazemos mal (BECKETT, 2010, p. 51-52). 


\title{
CONSIDERAÇÕES FINAIS
}

\begin{abstract}
Graças ao senhor é mais fácil viver, porque o senhor nos inspira fé em um futuro melhor e nos obriga a ter paciência para esperá-lo.

Carta de Meyerhold a Tchékhov, dez. $1901^{62}$
\end{abstract}

Ao beirarem o esgotamento do diálogo - a forma dramática por excelência - ainda que não tenham prescindido ou rompido totalmente com ele, as quatro peças de Tchékhov analisadas abriram definitivamente novos caminhos para a dramaturgia e o teatro do século XX, inaugurando uma nova fase da produção dramática, liberta do aristotelismo de relações de causa e efeito, dos grandes acontecimentos do enredo, de personagens polarizadas em protagonistas e antagonistas diretos.

Tchékhov, como notado na introdução, não estava sozinho na criação de uma nova linguagem teatral; o "drama novo" de Ibsen, Maeterlinck e Strindberg simultaneamente se desenvolvia, instaurando mudanças profundas que influenciaram o futuro da dramaturgia. Ainda assim, como observa Tchudakhov (1983, p. 218), foi Tchékhov quem se tornou o pai do teatro do século XX, pois seu sistema dramático foi a fonte para todas as novas estéticas teatrais. A razão para tal fato não estaria apenas nas diversas inovações empreendidas pelo autor, mas no novo modo de pensamento artístico que Tchékhov "consistentemente demonstrou, revertendo convenções anteriores limitadoras, aparentemente inflexíveis" (CHUDAKHOV, 1983, p. 218, grifo do autor).

Se a aproximação entre Tchékhov e dramaturgos do século XX foi notada por muitos críticos e pesquisadores (CHUDAKHOV, 1983; GILMAN, 1975, KATAEV, 2002; dentre outros), o diretor russo Liév Dódin em sua montagem de A gaivota (2001) realizou precisamente em cena, a justaposição entre o teatro de Anton Tchékhov e o teatro de um dos maiores expoentes das artes cênicas do século XX, Samuel Beckett ${ }^{63}$.

O monólogo de Nina, no início de A gaivota, no metateatro proposto por Tchékhov, assume, na montagem de Dódin, traços da estética beckettiana. As "formas novas" apregoadas por Tréplev, cansado do teatro estabelecido em que sempre se apresenta "a mesma coisa", fragmentam o corpo, como no teatro de Beckett, e Nina se torna, assim como Winnie de Dias

\footnotetext{
${ }^{62}$ apud TAKEDA, 2003, p. 196.

${ }^{63}$ Embora comentemos aqui a encenação de Dódin, vale lembrar que outros encenadores também realizaram em cena a aproximação entre os universos de Tchékhov e Beckett; é o caso do diretor francês Stéphane Braunscheig (1964-) e sua encenação de $O$ jardim das cerejeiras, de 1992, por exemplo.
} 
felizes (1961), Nagg e Nell de Fim de partida, das três "personagens-jarro" de Comédia, uma "cabeça-falante", pressionada pela necessidade constante e absoluta de falar, mesmo para uma plateia "em que ninguém escuta", para o vazio:

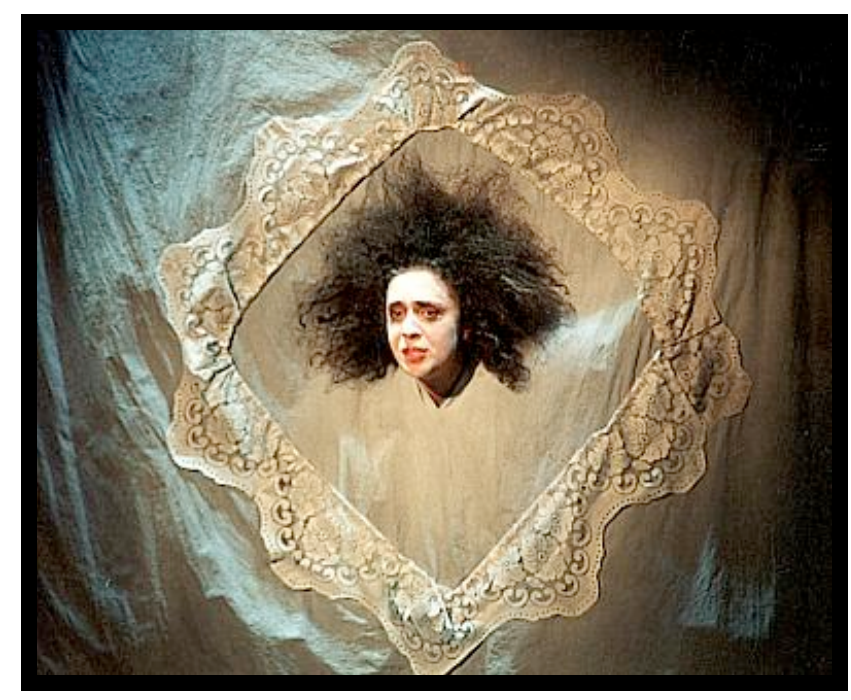

Nina / A Alma do Mundo (Ksénia Rappoport) na montagem de $A$ gaivota de Liév Dódin ${ }^{64}$.

A solidão e incomunicabilidade da "Alma do Mundo" na encenação de Tréplev/Dódin, em que o movimento do tempo parece suspender-se, eternizando o presente sem fim, ao vestirem a forma beckettiana adquirem ainda maior relevo; descortina-se, portanto, a potencialidade do texto tchekhoviano, que se abre para inúmeras possibilidades.

A abertura encontrada pelos encenadores nas peças de Tchékhov revela a universalidade de uma poética que se liberta do enredo de acontecimentos, encadeados por relações de causa e efeito, de conflitos externos nitidamente definidos, de personagens divididas entre heróis e vilões. Tchékhov abre espaço para que sejam retratados os universos individuais, as configurações espirituais das personagens. Estas passam a "reagir", muito mais do que "agir". Enquanto no sistema dramático tradicional, as personagens estão em constante luta para a realização de seus objetivos, vencendo ou sendo vencidas por obstáculos, na poética dramática tchekhoviana tornam-se eternamente sujeitas às forças externas que não podem controlar e que também as impedem de realizar as mudanças com que tanto sonham.

O mecanismo interdependente entre conflito e diálogo que impulsiona a ação no gênero dramático rigoroso, em que se priorizam os acontecimentos, concretizados como resultados do embate travado pelas personagens, no teatro tchekhoviano é interrompido; a ação é enfraquecida, ainda que transformação seja umas das palavras-chave da dramaturgia

\footnotetext{
${ }^{64}$ Disponível em: http://www.mdt-dodin.ru. Acesso em: 03 dez. 2010.
} 
de Tchékhov. As mudanças, contudo, deixam de ser resultados de conflitos resolvidos, para evidenciarem-se como consequências da passagem inevitável do tempo, movimento contínuo e inexorável; concentram-se no interior das personagens e refletem-se metaforicamente nos espaços que diminuem, nos invernos que se aproximam, nas árvores que deixam de existir, nas partidas e ausências, no passado que se torna vaga lembrança, no futuro que se torna hoje.

O tempo tornado o grande protagonista das obras é, por certo, decorrência da emersão de elementos épicos e líricos na forma dramática; o diálogo tchekhoviano deixa de gerar ação, abandonando a lógica aristotélica que lhe assegurava unidade, para se converter em expressão da alma das personagens; como nos trabalhos épicos, as peças passam a ter conexão direta com o espaço do "lá fora", que foge à realidade material e presente da cena representada, mas que se torna essencial pela relação que as personagens estabelecem com estes espaços; os grandes acontecimentos também vêm a ser abrigados por este "lá fora", abandonando o centro do palco e transformando-se em narrativas; a natureza dialoga diretamente com as personagens, tornando-se uma delas; o poder de concisão e brevidade de Tchékhov faz com que pequenos detalhes atinjam dimensões poéticas, metafóricas, abrindo portas para o infinito.

Desta maneira, o novo conteúdo abordado por Tchékhov, dada a resistência oferecida pela forma dramática tradicional, exigiu do autor a adoção de novos procedimentos, que chocaram leitores/espectadores da época pelo seu ineditismo e estranhamento. Dentre estes procedimentos, destacam-se o subtexto, o "invisível" e o "indizível", tão bem compreendidos por Stanislávski e Nemiróvitch-Dântchenko, como fundamentais à realização da cena tchekhoviana; sustentados pela intricada e delicada teia de relações entre as personagens, instauram um campo elétrico não só no palco, mas principalmente entre palco e plateia.

Partindo do universo interno de cada personagem, a ação dilata-se e transborda qualquer unidade que pretenda amarrá-la, pluralizando o tempo presente da cena representada, ao lançar-se às diferentes camadas de passado e de futuro livremente.

Assim, espaços e objetos, a partir de sua própria concretude material, adquirem dimensões simbólicas, abarcando novas extensões "invisíveis", nascidas da relação com as personagens. $\mathrm{O}$ jardim das cerejeiras, por exemplo, torna-se memória viva de diversos tempos passados: de lá ouvem-se vozes de crianças de muitas gerações, alegres ou oprimidas; de lá surgem reflexos de felicidade e de luto, de abundância e miséria. Da mesma forma, o pássaro que dá título à peça de Tchékhov torna-se símbolo; apesar de estar morto em cena, também evoca extensões "invisíveis", a partir das relações traçadas pelas personagens; a gaivota mesmo morta, não deixa de remeter ao voo que empreendera momentos antes; metaforiza o 
pressentimento de uma condição futura; ou ainda eterniza-se no desvario e euforia de uma lembrança.

As palavras também adquirem traços paradoxais, já que por vezes não possibilitam a expressão do que se deseja e por outras tornam-se desnecessárias, dispensáveis na comunicação com o outro. No "invisível", no "indizível", latente nos problemas de comunicação, encontram-se os desejos, medos, aflições e conflitos das personagens. Ao fazer destas camadas o coração de seu teatro, Tchékhov substitui pontos finais por interrogações e reticências, verdadeiramente "dialogando" com o leitor/espectador até os dias de hoje.

Assim, Tchékhov cria um sistema dramático em que se sobressai o próprio fluxo da vida, em que fragilidade, insignificância e não permanência deparam-se com a força do que é infinito.

Em As três irmãs, por exemplo, Tusenbach conclui que em duzentos ou trezentos anos, apesar dos progressos a serem empreendidos, a vida continuará a mesma: "[...] difícil, misteriosa e feliz. E passados mil anos o homem estará suspirando como agora: 'Como é difícil viver!'- e ao mesmo tempo temerá a morte e não irá querer morrer, exatamente como agora" (TCHÉKHOV, 2006b, p. 29).

A morte, onipresente nas peças de Tchékhov, não só nas ausências que se constituem, mas também nas falas das personagens (em As três irmãs, por exemplo, Olga recorda-se da morte do pai, que por sua vez lhe evoca a imagem de Irina "estendida aqui no chão como um cadáver"; Andrei culpa o ambiente degradado que arruína as crianças e as convertem em "cadáveres miseráveis, semelhantes entre si, como foram seus pais"), compõe com a vida um único ciclo. Como notou o diretor Peter Brook, cria-se, na dramaturgia de Tchékhov, "certa harmonia entre a vida e a morte, conforme acontece nas grandes tragédias" (BROOK, 1994, p. 212).

As personagens tchekhovianas, voando em sonhos e paralisadas na terra, justamente por sua fragilidade ante o fluxo inevitável do tempo e da própria vida, aprenderam a resistir. Com a persistência, a capacidade de suportar, descobriram que embora seus sonhos não se realizem, a vida ainda vale a pena; continuam a olhar as estrelas, apesar dos tropeços inevitáveis. Não desistiram. Talvez porque, como nos diz Vladímir Nabókov (1981, p. 254), a lei mais admirável, dentre todas as leis admiráveis da Natureza, seja precisamente esta: a sobrevivência dos mais fracos.

A poética dramática de Tchékhov, configura-se, assim, na leveza e na sutileza, impressas por um artista que não ignorava a dor nem o desespero, mas que olhava a vida com um riso bom. Stanislávski assim o testemunha: 
Eu o vejo animado e rindo bem mais frequentemente do que sombrio, apesar de o haver visto nos períodos graves de sua doença. Onde estava o doente Tchékhov reinava mais amiúde a brincadeira, a piada, o riso e até a travessura. Quem melhor do que ele sabia rir ou dizer bobagens com a cara séria? Quem odiou mais do que ele a ignorância, a grosseria, as lamúrias, a bisbilhotice, a trivialidade e o eterno beber chá! Quem mais do que ele teve sede de vida, de cultura, independente das formas em que se manifestassem? Qualquer iniciativa nova, útil - uma sociedade científica nascente ou projeto de um novo teatro, biblioteca ou museu - era para ele um verdadeiro acontecimento (STANISLAVSKI, 1989, p. 365-366).

Ao fim do percurso desta pesquisa, fico com a sensação de que ao ler, discutir e encenar as obras de Anton Pávlovitch Tchékhov, tornamos o mundo um pouco melhor do que ele realmente é; ainda que nossas perguntas permaneçam sem respostas, sentimo-nos estranhamente mais confiantes diante da vida. 


\section{BIBLIOGRAFIA}

\section{De Tchékhov}

CHEKHOV, A. Note-book of Anton Chekhov. Trad. S. S. Koteliansky e Leonard Woolf. Disponível em: http://www.gutenberg.net/1/2/4/9/12/12494. Acesso: 10 abril 2009. . The complete plays. Trad. Laurence Senelick. New York: W.W. Norton \& Co., 2006. . The plays of A. Chekhov. Trad. Constance Garnett. New York: Random House, [s.d.].

TCHÉKHOV, A. A dama do cachorrinho e outros contos. Trad. Boris Schnaiderman. São Paulo: Editora 34, 2005. . A estepe - história de uma viagem. Trad. José Pereira Júnior. São Paulo: Nova Alexandria, 2003. . A gaivota. Trad. e posfácio Rubens Figueiredo. São Paulo: Cosac \& Naify, 2004. - As três irmãs. Trad. Klara Gouriánova. Prefácio Elena Vássina. São Paulo: Ed. Peixoto Neto, 2004. . Cartas a Suvórin [1886-1891]. Introdução, tradução e notas: Aurora Fornoni Bernardini e Homero Freitas de Andrade. São Paulo: Edusp, 2002. . Ivánov. Trad. Arlete Cavaliere e Eduardo Tolentino Araújo. São Paulo: Edusp, 1998. Minha vida - relato de um provinciano. Trad. Sérgio Borín. São Paulo: Nova Alexandria, 2004.

. Os males do tabaco e outras peças em um ato. Seleção, organização e notas Homero Freitas de Andrade. São Paulo: Ateliê Editorial, 2003.

2002 . O assassinato e outras histórias. Trad. Rubens Figueiredo. São Paulo: Cosac \& Naif, O beijo e outras histórias. Trad. Boris Schnaiderman. São Paulo: Ed. 34, 2006. . O violino de Rothschild e outros contos. Trad. Noé Silva. Mairiporã: Veredas, 1991. O Silvano. Trad. Tatiana Lárkina. São Paulo, Ed. Globo, 2005.

. Sem trama e sem final: 99 conselhos de escrita. Trad. do italiano e do russo e notas Homero Freitas de Andrade. São Paulo: Martins Fontes, 2007.

. Sobránie sotchinéni (Obras completas [em russo]). Moscou: Editora Naúka, 1974, 1983, 30 vols.

. Teatro I: A gaivota, O tio Vânia. Trad. Gabor Aranyi. Mairiporã: Veredas, 1998.

Teatro II: As três irmãs, O Jardim das Cerejeiras. Trad. Gabor Aranyi. Mairiporã: Veredas, 2006.

Sobre Tchékhov

ANGELIDES, Sophia. A. P. Tchékhov: cartas para uma poética. São Paulo: Edusp, 1995. 2001. . Carta e literatura: correspondência entre Tchékhov e Górki. São Paulo: Edusp,

BISCHOF, Betina. Um improvável precursor: Tchecov e Kafka. In: Literatura e Sociedade, São Paulo, nº 9, p. 112-123, 2006.

CASTORF, Frank. Chekhov as the intellectual item of Russian exports. In: INTERNATIONAL CONFERENCE A WORD ABOUT CHEKHOV, 2010, Moscou. 
Moscou: Ministério da Cultura da Federação Russa; Departamento de Cultura da Cidade de Moscou, 2010, p. 109-111.

CHUDAKOV, A. P. Chekhov's poetics. Trad. Edwina Jannie Cruise, Donald Dragt. Ann Arbor: Ardis, 1983.

FERNANDES, Silvia; RAMOS, Luiz Fernando. Diálogo da Gaivota. Revista Sala Preta, São Paulo, n'. 7, p. 225-228, 2007.

FINKE, Michael. Seeing Chekhov: life and art. New York: Cornell University Press, 2005.

GÓRKI, Máximo. Três russos e como me tornei um escritor. Trad. Klara Gouriánova. São Paulo: Martins Fontes, 2006.

GOTTLIEB, Vera. Rough Chekhov. Disponível em: www.nationaltheatre.org.uk/? lid=2625. Acesso: 24 mar. 2009.

(Org.); ALlAIN, Paul (Org.). The Cambridge companion to Chekhov. Cambridge: Cambridge University Press, 2000.

KATAEV, Vladimir. If only we could know: an interpretation of Chekhov. Trad. Harvey Pitcher. Chicago: Ivan R. Dee, 2002.

LOUNSBERY, Anne. To Moscow I beg you!: Chekhov's vision of the Russian provinces. Toronto Slavic Quarterly $n^{\circ} .9$ (verão 2004). University of Toronto. Academic Journal in Slavic Studies. Disponível em: http://www.utoronto.ca/tsq/ 09/ lounsbery09.shtml. Acesso: 10. jul. 2009.

MANN, Thomas. Ensaio sobre Tchékhov. In: Ensaios. Trad. Natan Robert Zins. Anatol Rosenfeld (Org.). São Paulo: Perspectiva, 1988.

PITCHER, Harvey J. The Chekhov play: a new interpretation. Berkeley: University of California Press, 1985.

PRITCHETT, V. S. Chekhov: a spirit set free. New York: Random House, 1988.

RAYFIELD, Donald. Anton Chekhov: a life. New York: Henry Holt \& Company, 1998. . Chekhov: the evolution of his art. Plymouth: Elek Books, 1975.

REID, John McKellor. The polemical force of chekhovian comedies: a rhetorical analysis. Lampeter: The Edwin Mellen Press, 2007.

SCHIÉPKINA-KUPIÉRNIK, T. L. O Tchekhove. In: GUIÓVITCH, A. P. Tchekhov v vospominaniiakh sovremennikov [A. P. Tchékhov nas memórias dos contemporâneos]. Moscou: Khudojestvénnaia literatura, 1986, p. 247.

SENELICK, Laurence. Offenbach and Chekhov; Or, La Belle Yelena. Theatre Journal, vol. 42, $\mathrm{n}^{0} .4$, Disciplines of Theatre: Fin De Siècle Studies (dez. 1990), p. 455-467. The Johns Hopkins University Press. Disponível em: http://www. jstor.org/stable/3207722. Acesso: 07 mai. 2008. 
SHAPIRO, Adolf. "The Amarcord" of our culture. In: INTERNATIONAL CONFERENCE A WORD ABOUT CHEKHOV, 2010, Moscou. Moscou: Ministério da Cultura da Federação Russa; Departamento de Cultura da Cidade de Moscou, 2010, p. 131-133.

SMELIANSKY, Anatoly. An apparatus activated to sense the future. In: INTERNATIONAL CONFERENCE A WORD ABOUT CHEKHOV, 2010, Moscou. Moscou: Ministério da Cultura da Federação Russa; Departamento de Cultura da Cidade de Moscou, 2010, p. 139143.

STEIN, Peter. Chekhov makes one question his existence. In: INTERNATIONAL CONFERENCE A WORD ABOUT CHEKHOV, 2010, Moscou. Moscou: Ministério da Cultura da Federação Russa; Departamento de Cultura da Cidade de Moscou, 2010, p. 80-81.

STELLEMAN, Jenny. Aspects of dramatic communication: action, non-action, interaction (A. P. Cechov, A. Blok. D. Charms). Amsterdam: Rodopi, 1992.

STIEPANOV, Andrei. Problémi communikatsii u Tchékhova [Problemas de comunicação na obra de Tchékhov]. Moscou: Iaziki Slaviánskoi Culturi, 2005.

STREHLER, Giorgio. "La Cerisaie" de Tchekhov (1974). In: . Un Théatre Pour La Vie. Trad. Emmanuelle Genevois. Paris: Fayard, 1980.

TOLMATCHÍOV, Vassíli. O não-visual no drama novo. Trad. Noé Silva. In: Teatro russo literatura e espetáculo. São Paulo: Ateliê Editorial, 2010. No prelo.

WILLIAMS, Raymond. "A Gaivota", de Tchékhov, 1898. In: . Drama em cena. Trad. Rogerio Bettoni. São Paulo: Cosac \& Naify, 2010.

ZUBAREV, Vera. A system approach to literature: mythopoetics of Chekhov's four major plays. Westport, Conn. - London: Greenwood Press, 1997.

Sobre teoria teatral e teatro russo

ARISTÓTELES. Arte retórica e arte poética. Trad. Antônio Pinto de Carvalho. Intr. e notas Jean Voiquin e Jean Capelle. Estudo introdutório Goffredo Telles Júnior. Rio de Janeiro: Ediouro, [s.d.].

BENTLEY, Eric. A experiência viva do teatro. Trad. Álvaro Cabral. Rio de Janeiro: Zahar Editores, 1967.

BROOK, Peter. O ponto de mudança: quarenta anos de experiências teatrais. Trad. Antonio Mercado e Elena Gaidano. Rio de Janeiro: Civilização Brasileira, 1994. . The empty space. London: Penguin Classics, 1991.

CARLSON, Marvin. Teorias do teatro. Trad. Gilson César Cardoso de Souza. São Paulo: Ed. UNESP, 1997.

ESSLIN, Martin. Uma anatomia do drama. Trad. Bárbara Heliodora. Rio de Janeiro: Zahar Editores, 1978. 
GILMAN, Richard. The making of modern drama. New York: Farrar, Straus and Giroux, 1975.

GUINSBURG, Jacó. Stanislávski e o Teatro de Arte de Moscou. São Paulo: Perspectiva, 2006.

Stanislávski, Meierhold \& Cia. São Paulo: Ed. Perspectiva, 2001.

IONESCO, Eugène. Notes et contre-notes. Paris: Gallimard, 1991.

MENEZES, Tereza. Ibsen e o novo sujeito da modernidade. São Paulo: Perspectiva, 2006.

MIRSKY, D. S. A history of Russian literature. London: Routledge \& Kegan Paul, 1949.

MUKAROVCKY, Jan. Sobre o diálogo cênico. In: GUINSBURG, Jacó (Org.), TEIXEIRA COELHO (Org.), CARDOSO, Reni Chaves (Org). Semiologia do teatro. São Paulo: Perspectiva, 1988.

PAVIS, Patrice. Dicionário de teatro. Trad. Jacó Guinsburg e Maria Lúcia Pereira. São Paulo: Perspectiva, 2008.

PICON-VALlin, Béatrice. A cena em ensaios. (Sel. e Org.) Béatrice Picon-Vallin e Fátima Saadi. Trad. Fátima Saadi, Cláudia Fares e Eloisa Araújo Ribeiro. São Paulo: Perspectiva, 2008.

ROSENFELD, Anatol. O teatro épico. São Paulo: Perspectiva, 2010.

ROUBINE, Jean-Jacques. A linguagem da encenação teatral. Trad. Yan Michalski. Rio de Janeiro: Jorge Zahar, 1998.

Zahar, 2003.

Introdução às grandes teorias do teatro. Trad. André Telles. Rio de Janeiro: Jorge

RUDNITSKY, Konstantin. Russian and Soviet theatre: tradition and the avant-garde. Trad. Roxane Permar. London: Thames and Hudson, 1988.

SENELICK, Laurence (Trad. e Ed.). Russian dramatic theory from Pushkin to the symbolists. Austin: University of Texas Press, 1981.

STANISLAVSKI, Konstantin S. Minha vida na arte. Trad. Paulo Bezerra. Rio de Janeiro: Civilização Brasileira, 1989.

SZONDI, Peter. Teoria do drama burguês. Trad. Luiz Sérgio Repa. São Paulo: Cosac \& Naify, 2005.

Teoria do drama moderno [1880-1950]. Trad. Luiz Sérgio Repa. São Paulo: Cosac \& Naify, 2001.

TAKEDA, Cristiane L. O cotidiano de uma lenda: cartas do Teatro de Arte de Moscou. São Paulo: Perspectiva, 2003.

WILLIAMS, Raymond. Tragédia moderna. Trad. Betina Bischof. São Paulo: Cosac \& Naify, 2002. 


\section{Outras Obras}

AARÃO, Daniel Reis Filho. As revoluções russas e o socialismo soviético. São Paulo: Ed. UNESP, 2003.

ADORNO, Theodor W. Notas de literatura I. Trad. Jorge de Almeida. São Paulo: Duas Cidades; Ed. 34, 2003.

ANDRADE, H. F. (Org.), CAVALIERE, A. (Org.), SILVA, N. (Org.), VASSINA, E. (Org.). Caderno de literatura e cultura russa. São Paulo: Ateliê Editorial, 2004.

BAKHTIN, Mikhail. Estética da criação verbal. Trad. Paulo Bezerra. São Paulo: Martins Fontes, 2003.

. Problemas da poética de Dostoiévski. Trad. Paulo Bezerra. Rio de Janeiro: Forense Universitária, 2010.

. Epos e romance. In:

- Questões de literatura e estética: a teoria do romance.

Trad. Aurora Fornoni Bernardini. São Paulo: Ed. UNESP, 1993.

BECKETT, Samuel. Fim de Partida. Trad. e prefácio Fábio de Souza Andrade. São Paulo: Cosac \& Naify, 2010.

BERDIAÉV, N. A ideia russa - problemas básicos do pensamento russo do século XIX e do início do Século XX. Trad. José Mata Veríssimo e Elena Vássina. In: Revista de estudos orientais, $n^{\circ}$. 4. São Paulo: FFLCH/USP, 2003.

BERMAN, Marshall. Tudo o que é sólido desmancha no ar - a aventura da modernidade. Trad. Carlos Felipe Moisés e Ana Maria L. Ioriatti. São Paulo: Companhia das Letras, 1999.

CAMPOS, Haroldo. Qohélet = O-que-sabe: Eclesiastes: poema sapiencial. São Paulo: Perspectiva, 2004.

HEGEL, G.W.F. Os diferentes gêneros poéticos. In: Estética (III Parte - Sistema das artes, III seção - pintura, música, poesia). Trad. Álvaro Ribeiro e Orlando Vitorino. Lisboa: Guimarães Editores, 1993.

JAKOBSON, Roman. Linguística e comunicação. Trad. Izidoro Blikstein. São Paulo: Cultrix, 2001.

Poética em ação. Trad. João Alexandre Barbosa. São Paulo: Perspectiva, 1990.

KANDINSKY, Wassily. Do espiritual na arte e na pintura em particular. Trad. Álvaro Cabral. São Paulo: Martins Fontes, 1996.

LOTMAN, Yuri. Estética e semiótica do cinema. Trad. Alberto Carneiro. Lisboa: Editorial Estampa, 1978.

. A estrutura do texto artístico. Trad. Maria do Carmo Vieira Raposo e Alberto Raposo. Lisboa: Editorial Estampa, 1978.

. Universe of the mind: a semiotic theory of culture. Trad. Ann Shukman. Bloomington Indiana University Press, 1990. 
LUKÁCS, Georg. A teoria do romance. Trad., posfácio e notas José Marcos Mariani de Macedo. São Paulo: Duas Cidades/Editora 34, 2006.

NABOKOV, Vladimir. Lectures on Russian literature. New York: Harcourt Barce, 1981.

PAZ, Octavio. A dupla chama: amor e erotismo. São Paulo: Siciliano, 1994.

PESSOA, Fernando. Livro do desassossego: composto por Bernardo Soares, ajudante de guarda-livros na cidade de Lisboa. São Paulo: Companhia de Bolso, 1986.

PROPP, Vladímir. Comicidade e riso. Trad. Aurora Fornoni Bernardini e Homero Freitas de Andrade. Sao Paulo: Ed. Ática, 1992.

SCHWARZ, Roberto. Cultura e política. São Paulo: Paz e Terra, 2009.

TARKOVSKI. Esculpir o tempo. Trad. Jefferson Luiz Camargo. São Paulo: Martins Fontes, 2002.

TCHERNYCHEVSKI, Nikolai G. What is to be done? Tales of a new people. Trad. Laura Beraha. Moscow: Raduga Pub, 1983.

TOMACHEVSKI, B. Temática. In: TOLEDO, Dionísio de Oliveira. Teoria da literatura formalistas russos. Trad. Ana Mariza Ribeiro Filipouski, Maria Aparecida Pereira, Regina L. Zilberman, Antônio Carlos Hohlfeldt. Porto Alegre: Globo, 1973.

TOLSTÓI, Lév. Anna Kariênina. Trad. Rubens Figueiredo. São Paulo: Cosac \& Naify, 2005.

VÁSSINA, E., SCHNAIDER, G. Tradução e Prefácio de TOLSTÓI, L. O cadáver vivo. São Paulo: Peixoto Neto, 2007.

VÁSSINA, E. O Eterno Tchékhov. In: GARCIA, Silvana (Org.). Os grandes dramaturgos. A. Tchékhov. As Três Irmãs. São Paulo: Peixoto Neto, 2004.

Teses e Dissertações

BERTON, Paulo Ricardo. O conceito de protagonista na obra dramática de Anton Tchékhov. Dissertação (mestrado), Faculdade de Letras da Pontifícia Universidade Católica do Rio Grande do Sul, Porto Alegre, 2007.

D'AGOSTINI, Nair. O método de análise Ativa de K. Stanislávski como base para a leitura do texto e da criação do espetáculo pelo diretor e ator. Tese (Doutorado em Literatura e Cultura Russa), Departamento de Letras Orientais, Faculdade de Filosofia, Ciências e Letras, Universidade de São Paulo, São Paulo, 2007.

LÁRKINA, Tatiana. De o ingênuo Silvano a Tio Vânia: um estudo biográfico do teatro de Tchékhov. Dissertação (mestrado), Departamento de Letras Orientais da Faculdade de Filosofia, Letras e Ciências Humanas, Universidade de São Paulo, São Paulo, 2003. 


\section{ENCENAÇÕES E FILMES CITADOS}

(Fichas técnicas)

A GAIVOTA (2001). Dir.: Liév Dódin. Assistentes de direção: Oleg Dmitriev e Natália Kolotova. Produção: Olga Dazidenko. Figurinos: Maria Fomina e Irian Tsvetkova. Cenários: Alexêi Poray-Kochits. Com: Tatiana Chestakova, Alexander Zavialov, Serguei Kurichév, Ksénia Rappoport, Oleg Gaianov, Natalia Akimova, Maria Nikiforova, Irina Tichinina, Serguei Kurichev, Igor Tchernevitch, Petr Semak, Vladímir Seleznev, Alexander Koshkarev e Serguei Muchenikov.

AS TRÊS IRMÃS (2004). Dir e produção: Piotr Fomenko. Assistente de direção: Ivan Verkhovik. Assistente de produção: Vladímir Maksímov. Figurinos: Maria Danílova. Iluminação: Vladislav Frólov e Evguêni Vinográdov. Música: Globa Oksana, Vladímir Mouat. Com: Andrei Kazakóv, Galina Tiunina, Pauline Kutépova, Ksénia Kutépova, Madeleine Dzhabrailóv, Tagir Rakhimóv, Rustem Iuskaiév, Kirill Pirogov, Karen Badalov, Ivan Verkhovik, Stiepan Piankóv, Igor Ovchinnikóv, Serguei Iakubenko, Ludmila Dolgorukóv, Elena Voronchikhin, Oleg Liubímov, Anna Rodiónova, Vladímir, Toptsov, Vladímir Mouat, Iúri Stepanóv, Ludmila Arinin.

DOSSIE TARKOVSKI (Stálker + Nostalgia + Sacrificio). Volume IV. Entrevistas com o diretor de fotografia de Stálker, Alexander Kniazhinski; o designer de produção de Stálker Rashit Safiullin. Cenas inéditas da casa de Tarkóvski. Trailler de Nostalgia. Documentário (making of de Sacrifício) de Michal Leszczilowski. Biografia dos atores e equipe técnica. Galeria de pôsteres. Arquivo de fotos. Trailler original de Andrei Rubliov. Continental HomeVideo. DVD (123 min.), 4:3, letterbox, colorido, NTSC, dolby digital 2.0, em russo. Legendas em português, inglês e espanhol.

O JARDIM DAS CEREJEIRAS (1974). Dir. Giorgio Strehler. Trad. Luigi Lunari, Giorgio Strehler. Cenários e figurinos: Luciano Damiani. Música: Fiorenzo Carpi. Com: Cip Barcellini, Valentina Cortese, Franco Graziosi, Monica Guerritore, Claudia Lawrence, Giulia Lazzarini, Gianfranco Mauri, Marisa Minelli, Renzo Ricci, Piero Sammataro, Gianni Santuccio, Enzo Tarascio. Produção: Piccolo Teatro Milano.

O TIO VÂNIA (1971). Dir. Andrei Konchalóvski. Roteiro: Andrei Konchalóvski baseado na peça de Anton Tchékhov. Com: Andrei Konchalóvski, Innokénti Smoktunóvski, Serguei Bondarchuk, Gueórgui Rerberg, Irina Kúpchenko, Irina Mirochnitchenko, Vladímir Ziéldin. Fotografia: Evguêni Guslínski, Gueórgui Rerberg. 110 min. Mosfilm. Original em russo: Diadia Vânia.

TCHÉKHOV ${ }^{4}$ - UMA EXPERIÊNCIA CÊNICA (2010). Dir.: Adolf Shapiro. Assistente de direção/Intérprete: Diego Moschkovich. Cenários: Hideki Matsuka. Figurinos: Simone Mina. Com: Aury Porto, Fredy Allan, Luah Guimarãez, Lúcia Romano, Sérgio Siviero, Sílvio Restiffe, Sylvia Prado e Vanderlei Bernardino (mundana cia.). Participação especial: Priscilla Herrerias e Tieza Tissi. Registro áudio-visual: Cacá Bernardes. Produção: Ricardo Muniz Fernandes e Matias Pees. Curadoria Espaço Tchékhov 2010: Elena Vássina. 